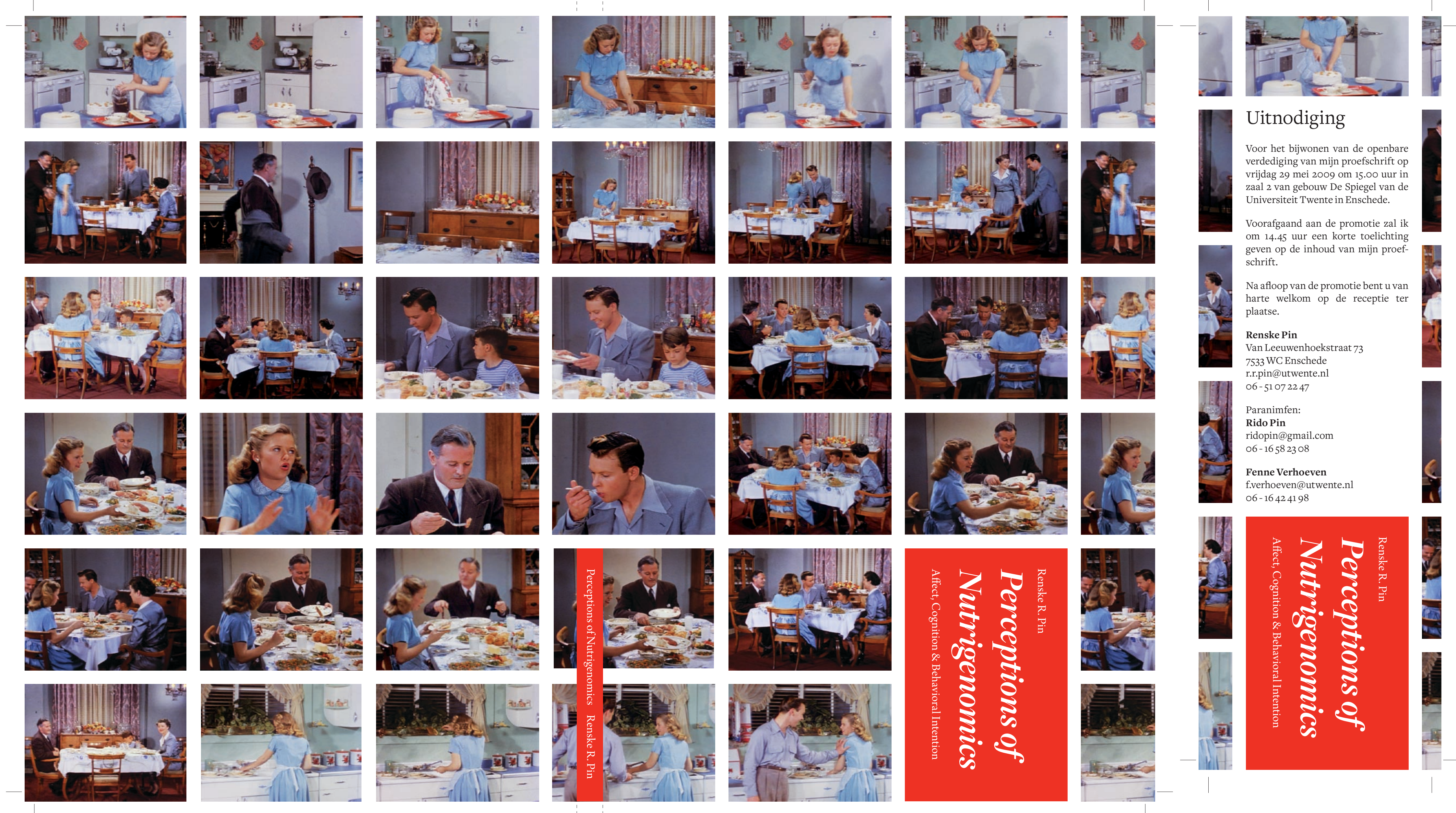




\section{PERCEPTIONS OF \\ NUTRIGENOMICS}

AFFECT, COGNITION \& BEHAVIORAL INTENTION

Renske R. Pin 
Thesis, University of Twente, 2009

(c) Renske R. Pin

ISBN: $978-90-365-2820-7$

Cover and bookdesign by Einszwei

Printed by Gildeprint Drukkerijen BV, Enschede, the Netherlands

The studies presented in this thesis were financially supported by the Centre for Society and Genomics. In this thesis use is made of data of the LISS panel administered by CentERdata. 


\section{PERCEPTIONS OF NUTRIGENOMICS}

AFFECT, COGNITION \& BEHAVIORAL INTENTION

\section{PROEFSCHRIFT}

ter verkrijging van

de graad van doctor aan de Universiteit Twente, op gezag van de rector magnificus, prof.dr. H. Brinksma, volgens besluit van het College voor Promoties in het openbaar te verdedigen op vrijdag 29 mei 2009 om 15.00 uur

door

Renske Roline Pin

geboren op 13 januari 1979

te Woerden 
Dit proefschrift is goedgekeurd door de promotoren prof. dr. Erwin R. Seydel en prof. dr. Lynn J. Frewer en de assistent-promotor dr. Jan M. Gutteling 
since feeling is first who pays any attention to the syntax of things will never wholly kiss you; wholly to be a fool while Spring is in the world my blood approves, and kisses are a better fate than wisdom

\section{E.E.Cummings}




\title{
Samenstelling promotiecommissie
}

\author{
Promotoren Prof. dr. Erwin R. Seydel \\ Prof. dr. Lynn J. Frewer \\ Assistent-promotor \\ Dr. Jan M. Gutteling \\ Leden \\ Prof. dr. Maarten J. IJzerman \\ Prof. dr. Michaël F. Steehouder \\ Prof. dr. Patricia Osseweijer \\ Prof. dr. Jan C. Terlouw \\ Prof. dr. Hub A. E. Zwart \\ Dr. Christine R. Critchley
}




\section{Contents}

Chapter 1.

Chapter 2.

Chapter 3.

Chapter 4.

Chapter 5 .

Chapter 6.

Summary

Samenvatting

Dankwoord
Introduction

The Development of Public Risk Perception Research in the Genomics Field: An Empirical Analysis of the Literature in the Field

Science Communication. Prepublished December 29, 2008.

Determinants of Reactions to Gene-technology:

A Generic Approach

New Genetics and Society 2009: 28(1), 51-65.

Understanding Public Perception of Personalised

Nutrition: A Comparison of Australia and The

Netherlands

Submitted

Intentions to Adopt Nutrigenomics: Personalized

Nutrition and Functional Foods

Submitted

Discussion

117

Summary in English

Summary in Dutch

139

Acknowledgements in Dutch

145 


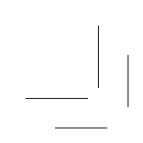

1 


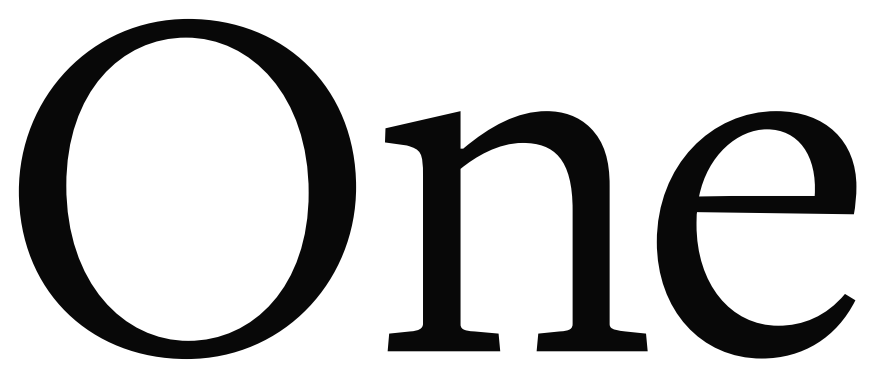

Introduction 


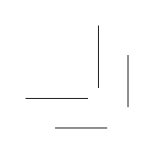

1 


\section{One}

Introduction

Public support of a technology and its applications is an important and necessary condition for successfully introducing a new technology in society, particularly if its commercialization is dependent on consumer products. Predicting the people's behavioral intentions with regard to the adoption of new technologies and the products of those technologies is important for technological development. If genomics technology can be used to predict diseases and prescribe preventive diets based on a person's genetic profile, it is important to understand the people's intention to adopt such personalized diets.

This thesis examines intentions regarding the adoption of nutrigenomics and considers the role of potentially influential psychological determinants in influencing a person's decision to adopt applications of nutrigenomics technology.

\subsection{Background}

\subsubsection{Public Perceptions of Technological Developments}

The social context which surrounds technology is likely to be one of the most important determinants of its future development and application. A potentially important component of this social context is the nature of public attitudes towards technology (Frewer, Howard, \& Shephard, 1998). Predicting the people's intentions to adopt new technologies and their applications is important for the development and success of those technologies (see for example, Flynn \& Bellaby, 2007). The relationship between technological innovation and societal responses has a long and complex history. Research has identified considerable variation in societal responses according to the area of application. In particular, societal responses to the application of different technologies in the agrifood sector has been a focus of societal concern in comparison to, for example, medical applications of technology (for example, as in the case of genetically modified foods towards the end of the last century) (Bredahl, 2001; Frewer et al, 2004). A question arises as to whether individual reactions to technologies applied in the agrifood sector will be more acceptable if health benefits can be identified (Schenk et al, 2008). The field of nutrigenomics is of interest here, as its application in food may be controversial in general, but the potential health benefits to individual consumers may result in positive societal responses, in particular because the application is perceived to be more closely linked to medicine than to food. 
The successful introduction of new technologies is dependent on public support, as reflected in their intention to adopt applications of these technologies despite the fact that many of these technologies have been developed with little or no regard for the likelihood of a positive reception from users (Henson, Annou, Cranfield, \& Ryks, 2008). More broadly, we need to understand the nature of the concerns individuals have about new technologies, such as genetic modification, in order to be able to incorporate societal concerns into risk governance practices (Siegrist, 2000). Indeed, it has been well established that the success of innovative activities within the food sector in particular is closely related to the level of understanding of consumer demand (see, e.g., Brown \& Eisenhardt, 1995; Gupta \& Wilemon, 1990; Cooper, 1994; Kristensen et al., 1997). This is well illustrated by notable cases (e.g., food irradiation) of seemingly valuable technologies, in terms of productive efficiency, product quality and safety that have met consumer resistance in the marketplace (Bord \& Connor, 1990; Malone, 1990; Hashim et al., 1995). In Europe, the case of GM foods is of particular interest, as intensive associated media coverage, largely negative in tone, occurred between 1996 and 2001 (Bauer \& Gutteling, 2006). This was accompanied by episodes of citizen mobilization in protest against field trials of GM crops, consumer resistance to GM foods, supermarket boycotts and, finally, a moratorium on the commercial planting of GM crops in the European Union in 1999.

Nutrigenomics can be associated with both medical- and food-related applications, and it is uncertain whether its commercial trajectory will result in applications primarily focused on (preventive) healthcare, commercialized food products, or both. The paradigms with which the reactions towards this technological development have been studied vary between public support studies, focusing on issues ranging from the public perception of risk to consumer acceptance studies which, for example, examine the consumers' willingness to buy and consume nutrigenomics products. Both paradigms, as well as being closely interrelated and interdependent research activities, have contributed significantly to our understanding of the process underlying the reactions to new technologies like nutrigenomics. Individual risk-benefit attitudes are uncrystallized and will therefore be influenced either by whatever information becomes available (including their personal experience of products) or will be derived from existing attitudes towards other (associated) technologies.

At this stage the technology has almost reached the very beginning of the transaction level (Horst, Kuttschreuter \& Gutteling, 2007). That is, consumers actually encounter nutrigenomics products and services; thus they are not exclusively dependent on the media as a source of information with which to form an opinion (Bauer \& Gutteling, 2006; Gutteling, 2005). At the present time, the first nutrigenomics products are becoming available to consumers in very early forms, e.g., genetic or DNA tests now available on the internet. However, experts still disagree on the exact form and future of nutrigenomics-based personalized nutrition. A timeframe of ten years has been set for moving the applications of nutrigenomics to the transaction level (Muller \& Kersten, 2003).

In this research, the paradigm utilized is embedded in theories developed in socio-psychological and communication studies. The aim is to assess the relationship between public support for nutrigenomics and behavioral intention. Specifically, it is set out to discover the existing level of public acceptance of nutrigenomics and how and when this translates to individual behavioral 
intentions to adopt applications of the new technology.

\subsubsection{An Emerging Technology: Nutrigenomics}

Throughout the 2oth century, nutritional science has focused on identifying vitamins, minerals, and other nutrients, defining their use in terms of human health. As the nutrition-related health problems of the developed world shifted to issues such as over-nutrition, obesity, type-two diabetes, cancer, and cardiovascular diseases, the focus of modern medicine and of nutritional science changed accordingly (Rodriguez, Munoz, \& Casieri, 2007).

In order to address the increasing incidence of these diet-related-diseases, the role of diet and nutrition has been and continues to be extensively studied. As more is known about human nutrition, more research questions can be identified. To prevent the development of disease, nutrition research is investigating how nutrition can optimize and maintain cellular, tissue, organ and whole body homeostasis (Afman \& Muller, 2006). This requires understanding how nutrients act at the molecular level, research which requires the investigation of a multitude of nutrient-related interactions at the gene, protein and metabolic levels. As a result, some nutrition research has shifted from epidemiology and physiology to molecularbiology and genetics (Muller \& Kersten, 2003), leading to the birth of nutrigenomics.

Nutrigenomics is the study of the molecular relationships between nutrition and the response of genes, and aims to identifyhow such changes can affecthumanhealth (Chavez \& de Chavez, 2003). Nutrigenomics focuses on the effect of nutrients on the genome, proteome, and metabolome. By determining the mechanism of the effects of nutrients or the effects of a nutritional regime, nutrigenomics tries to define the relationship between these specific nutrients and specific nutrient regimes (diets) on human health. Nutrigenomics has been associated with the idea of personalized nutrition based on genotype. While there is hope that nutrigenomics will ultimately enable personalized dietary advice, it is a science still in its infancy and its contribution to public health over the next decade is expected to be minor (Muller \& Kersten, 2003).

It is hoped that, by building up knowledge about the molecular relationships between nutrition and the response of genes, nutrigenomics will promote an increased understanding of how nutrition influences metabolic pathways and homeostatic control, which will then be used to prevent the development of chronic diet-related diseases such as type two diabetes and cardiovascular diseases. Part of the approach of nutrigenomics involves finding markers of the early phase of diet-related diseases. This early phase of disease is the stage at which intervention with nutrition can return the patient to health.

1.1.3 Applications of Genetic Engineering and Nutrigenomics Technology: GM-food, Personalized Nutrition and Functional Foods

When studying the public perception of new food technologies such as nutrigenomics, a differentiation has to be made between the public support for the technology and the public 
support of the use of the technology. One may approve of a technology but could be resistant towards its specific applications, or vice versa. In this thesis three different applications within this technological area will be topics of research: gene-technology, personalized nutrition and functional foods.

As nutrigenomics seeks to understand the effect of different genetic predispositions in the development of diseases, once a marker has been found and measured in an individual, the extent to which s/he is susceptible to the development of that disease can be quantified and personalized dietary recommendation can be offered. Nutrigenomics also aims to demonstrate the effect of bioactive food compounds on health, which should lead to the development of functional foods that will develop and maintain health according to the needs of the individual. Nutrigenomics is a rapidly emerging science still in its beginning stages. It is uncertain whether the tools to study protein expression and metabolite production have been developed to the point where efficient and reliable measurements can be made. Furthermore, the outputs of such research will need to be integrated in order to produce results and personalized dietary recommendations. All of these technologies are still in the process of development.

Gene-technology, and its most prominent application of genetic modification, is a technique used to alter or move genetic material (genes) of living cells. It is the artificial manipulation, modification and recombination of DNA or other nucleic acid molecules in order to modify an organism or population of organisms. In the case of Genetic Modification (GM), the hereditary material of a plant or animal is adapted (modified). This modification should have a positive impact on the phenotype or "product properties" of the plant or animal. One example is herbicide-resistant crops, where more herbicides can be applied to remove weeds without negatively affecting the crop. In the case of nutrigenomics, initial research activities must focus on the genetic make-up of individuals. Information about genetic make-up can be used to make inferences about the impact of nutrition on the human body. No hereditary human material is modified in the case of nutrigenomics (Vandeberg, 2009).

Although nutrigenomics is, in essence, different from GM, the technology associated with nutrigenomics may raise consumer concerns about how human genetics research can compromise the integrity of nature and have a negative impact on privacy (e.g., handling of DNA banks' subject's confidential information, as people with rare diseases may be easily identified). The issues of control over sensitive information are also highly relevant. In Canada, for example, it has been found that lay people strongly associate nutrigenomics research with the genetic modification of crops (Burgess, 2003). Such associations may be inevitable, and suggest that substantial attention should be paid to public expectations and concerns about the potential applications of nutrigenomics (Ronteltap, van Trijp, Renes, \& Frewer, 2007).

\subsubsection{Public Reactions to Applications of Nutrigenomics}

To date, little is known about what people think about the emerging technology of nutrigenomics. In this thesis, data were collected from a representative sample of the Dutch population. The results suggest that the public attitude towards nutrigenomics ranges from somewhat 
ambivalent to positive. Respondents were asked what their first reaction was when they initially encountered the topic of the survey. Their responses ranged from very positive (respondents indicated that they found the development very interesting, fascinating and relevant to society), to very sceptical, (respondents indicated that they were concerned about freedom of choice and commercialization, and associated it with genetic modification). The quantitative data demonstrate that in the case of personalized nutrition, respondents $(n=2170)$ were fairly positive about intending to take the genetic test and adopt a personalized nutrition plan $(\mathrm{M}=3.69, s d=$ $0.86,5$ point scale, $1=$ definitely not $-5=$ definitely). In the case of personalized nutrition, the freedom of choice of knowing what possible diseases they could get in the future appeared to be an important condition for the adoption of a personalized nutrition plan. Of the respondents, $30.6 \%$ indicated that they wanted to take a genetic test and adopt the recommended diet to prevent disease, but did not want to know what possible future diseases they may be susceptible to (see table 1).

Table 1

Intention to Adopt Personalized Nutrition $(\mathrm{n}=2170)$

\begin{tabular}{llll}
\hline \multicolumn{2}{c}{ Would you want to... } & \\
take the genetic test? & ...and know diseases? & $\begin{array}{l}\text {...and adopt diet to prevent } \\
\text { possible diseases? }\end{array}$ & $\%$ \\
\hline No & No & No & 21.7 \\
Yes & Yes & No & 3.2 \\
Yes & No & Yes & 30.6 \\
Yes & Yes & Yes & 40.8 \\
Something else, namely... & & & 3.7 \\
\hline
\end{tabular}

It can be concluded from the data that the Dutch participants in this study are ambivalentpositive about nutrigenomics, and will be convinced by information about potential benefits and positive arguments. However, this may be conditional on the implementation of regulations concerning some issues as the participants indicated that they are concerned about privacy (e.g., DNA storage), freedom of choice (e.g., in whether or not they know what possible diseases they may develop and whether or not adoption of a personalized diet will serve as an effective intervention), equality (e.g., in possibilities of obtaining health insurance and the social divide of the healthy and unhealthy) and commercialization (e.g., companies selling fake genetic tests on the internet).

In comparison to well formed attitudes about some other recent technological innovations, such as those associated with agricultural biotechnology and GM foods, public opinion on nutrigenomics is in the early stages of the issue cycle and - as a result - still very much in flux. In other words, public perception and attitudes can be affected by a wide range of issues including cognitive and affective variables (Lee et al., 2005). Nutrigenomics, therefore, provides a unique opportunity to examine public opinion formation on emerging technologies in the early stages 
of the "issue cycle", when citizens are only beginning to make sense of the costs and benefits connected with the new technology. The other question of interest here is whether every technology can start with a clean slate, or if there is the possibility of attitude activation. In other words, one might posit that attitudes towards new applications of technologies are derived from earlier attitudes associated with applications of technologies previously experienced, such as, genetically modified foods.

\subsection{Aim and Scope of the Thesis}

The aim of this thesis is to gain an understanding of the social psychological processes relevant to the people's intention to adopt nutrigenomics. To this end, a systematic review of the literature was employed to reveal the key determinants and various surveys to test and developed models that sense the most prominent predictors and underlying processes.

\subsubsection{Model}

Since the early 1980s, several models have been developed to explain and predict public reactions toward technological developments. These models specifically address the issue of risk perception, or the subjective judgment that people make about the characteristics and severity of a risk. These studies have provided an understanding of those cognitive determinants which predict an individual's perception of technology development. Recently, important advances have been made in the sense that social factors such as trust have been added to the models, and we see a trend toward the study of the role of affective factors (the experience of feeling or emotion) that influence public reactions towards risks and benefits of technology.

The recent psychological risk literature distinguishes between cognitive and affective components of perception (Slovic, Finucane, Peters \& MacGregor, 2004). The literature review in Chapter 2 identified both cognitive and affective determinants of the perception of genomics and its consequences. The 'cognitive system' uses algorithms and normative rules, with knowledge being one of the most important motives. This system is relatively slow, requiring effort and conscious control. Relying on images and associations linked by experience to emotion and affect (a feeling that something is good or bad), the 'affective system' is intuitive, fast, mostly automatic, and does not depend on conscious awareness. These two systems operate in parallel, possibly depending on each other for guidance (Slovic et al., 2004).

In this thesis, one aim of the research is to explore what factors have, to date, been found to predict an individual's intentions to adopt nutrigenomics. The focus is, in particular, on the relationship between cognitive and affective processes, and their relative importance in the intention to adopt an emerging food technology. Which process is more dominant? What underlying determinants initiate these cognitive and affective predictors? The role of trust and involvement in terms of their predictive capacity of the cognitive and affective processes is studied in depth. 


\subsubsection{Predictors of Reactions to Genomics}

In this thesis, a range of predictors for the reactions to genomics is explored and modeled. In table 2 an overview of the predictors included in each study is presented. The predictors included in the models developing range from broad to specific, zooming in on the strongest predictors and the most important processes and eliminating the less significant predictors. Below, the most prominent predictors included in the models presented in chapters 3 through 5 are briefly discussed.

Table 2

Predictors of reactions to genomics discussed in the four contributing papers

\begin{tabular}{|c|c|c|c|c|}
\hline & Chapter 2 & Chapter 3 & Chapter 4 & Chapter 5 \\
\hline Aim & $\begin{array}{l}\text { Important predictors of } \\
\text { reactions to genomics }\end{array}$ & $\begin{array}{l}\text { Reactions to } \\
\text { Genetechnology }\end{array}$ & $\begin{array}{l}\text { Intention to adopt } \\
\text { Personalized Nutrition }\end{array}$ & $\begin{array}{l}\text { Intention to adopt } \\
\text { Personalized Nutrition } \\
\text { and Functional Foods }\end{array}$ \\
\hline Method & Systematic Review & Survey & $\begin{array}{l}\text { Survey, Cross-national } \\
\text { (The Netherlands and } \\
\text { Australia) }\end{array}$ & $\begin{array}{l}\text { Survey, Longitudinal } \\
\text { \& External validation }\end{array}$ \\
\hline Result & Literature Review & Path Model & Structural Model & Structural Model \\
\hline \multirow[t]{7}{*}{ Predictors } & Experience & $x$ & & \\
\hline & Knowledge & $x$ & & \\
\hline & Trust & $x$ & $x$ & \\
\hline & $\begin{array}{l}\text { Cost/Benefit Ratio and } \\
\text { Perception }\end{array}$ & $\mathrm{x}$ & $\mathrm{x}$ & $x$ \\
\hline & Affect & $\mathrm{x}$ & $\mathrm{x}$ & $\mathrm{x}$ \\
\hline & $\begin{array}{l}\text { Personal Interest and } \\
\text { Involvement }\end{array}$ & $x$ & & $x$ \\
\hline & Attitude & & & $\mathrm{x}$ \\
\hline
\end{tabular}

Experience

An individual's experience and familiarity (Henneman 2004) with the technology is expected to play a role in the process of forming the intention to adopt applications of emerging technologies such as nutrigenomics. Horst et al (2007) found that experience with a technology is related to its perceived usefulness, where more experience increased perceived usefulness. Research on other new technologies has shown that experience with the technology under consideration can increase knowledge and interest (Grunert et al., 2003). As most people's experience with nutrigenomics technology is low, this predictor is hard to measure. However, gene technology applications have reached the transaction level (Horst, Kuttschreuter \& Gutteling, 2007) where consumers actually encounter gene technology products and services and are not exclusively dependent on information from the media in order to form an opinion (Bauer \& Gutteling, 2006; Gutteling, 2005). This predictor is included in the first model presented in this thesis 
(Chapter 3), which aims to model reactions to gene technology, with which it is postulated people are more familiar.

\section{Knowledge}

Knowledge is frequently studied as a predictor of public acceptance of technology in general and gene-technology in particular (Shaw, 2002). In the case of GM foods, there is some evidence to suggest that higher levels of knowledge coincide with higher levels of acceptance (Moerbeek \& Casimir, 2005). Against this, knowledge may be just one of the many factors that influence the opinions concerning GM foods (Cuite, Aquino, \& Hallman, 2005). Others have found that knowledge increases critical opinions about biotechnology (Bauer \& Gutteling, 2006). This predictor is included in the first model presented in this thesis (Chapter 3), which aims to model reactions to gene technology, a more commonly known technology.

Trust

Two types of trust can be distinguished (Frewer, 2003). 'Social trust' refers to trust in regulatory institutions with responsibility for consumer protection. 'Source credibility' refers to trust in information sources. Social trust is indicated by people's willingness to rely on experts and institutions when managing risks and technologies. According to Siegrist, Cvetkovich and Roth (2000), social trust is "the willingness to rely on those who have the responsibility for making decisions and taking actions related to the management of technology, the environment, medicine, or other realms of public health and safety" ( $p$ 354). Because the public generally has limited information, ability or time to understand the complexities of new or advanced technologies, they have to rely on information obtained from experts. This relates to 'source credibility' and refers to people's perceptions of the motivations of institutions or individuals providing information to the public. The model presented in Chapter 3 includes both types of trust as a predictor for the reactions to gene technology. The model in Chapter 4 includes trust in information sources as a predictor of the intention to adopt personalized nutrition.

\section{Cost/Benefit Ratio and Perception}

Perceptions of costs (or risks), benefits, and outcomes maybe potentiallyimportant determinants of reactions to new technologies (Gaskell et al, 2004; Ronteltap, van Trijp, Renes, \& Frewer, 2007). Public perception has been frequently studied in relation to new technologies, especially in cases where the technology could be associated with risks (Ronteltap, van Trijp, Renes, \& Frewer, 2007; Slovic, Peters, Finucane, \& MacGregor, 2005). If individuals perceive a benefit from a behavior or choice, the risk associated with this behavior or choice is perceived to be lower (Frewer et al., 2004). The concept of risk perception is frequently linked to safety issues. In the case of nutrigenomics the potential risks are mostly societal costs. A cost can be defined as an "exchange" or "loss" - risk is the probability multiplied by the hazard. If appropriately applied, health technologies such as personalized nutrition may greatly enhance existing models of health intervention. However, potential adverse consequences could arise, such as issues related to compromised privacy, confidentiality, and security; quality and effectiveness; and sustainability (Eng, 2004; Meijboom, Verweij, \& Brom, 2003). Attitudes toward engaging in behavior are determined by people's beliefs about the outcomes of performing the behavior under consideration, weighted by the public's subjective evaluation of these expected outcomes (Verdurme \& Viaene, 2003). The cost and benefits perception predictor is included in all three 
models (Chapter 3-5) presented in this thesis.

\section{Affect}

Affect, or emotional response, is a potentially important factor influencing decision-making processes. The feelings associated with perceived risk, and how these fast, instinctive, and intuitive reactions influence human decision-making have been studied (Slovic et al., 2005; Townsend, 2006). 'Affective evaluation' means the specific quality of "goodness" or "badness" (i) experienced as a feeling state (with or without consciousness) and (ii) demarcating a positive or negative quality of a stimulus. Affective responses occur rapidly and automatically. Slovic, Finucane, Peters, and MacGregor (2007) argue that reliance on such feelings can be characterized as "the affect heuristic." Although cognitive analysis is certainly important in some decisionmaking circumstances, reliance on affect is a quicker, easier, and more efficient way to navigate in a complex, uncertain, and sometimes dangerous world. This predictor is included in all three models (Chapter $3-5)$ presented in this thesis.

\section{Personal Interest and Involvement}

Little is known about the influence of an individual's involvement in a particular technology regarding their actual process of adoption or uptake of its applications. In the field of persuasion, however, involvement as a predictor of behavioral intention is more commonly studied, and it is considered to be an important factor which influences whether or not information about a topic results in persuasion, or attitude change (Park, Levine, Westerman, Orfgen, \& Foregger, 2007). Involvement may be defined as "the motivational state induced by an association between an activated attitude and some aspect of the self-concept" (Johnson \& Eagly, 1989). Petty et al. (1983) use the term "issue involvement" or "personal relevance" to refer to the extent to which a topic has personal meaning and important consequences for an individual. From their meta-analysis, Johnson and Eagly (1989) concluded that subjects with high outcome-relevant involvement (their ability to attain desirable outcomes) were more persuaded by strong arguments than were low-involvement subjects. Johnson (1994) found that prior information about a persuasive issue interacts with outcome-relevant involvement to effect attitude change. This predictor is included in the first (Chapter 3) and third model (Chapter 5) presented in this thesis.

\section{Attitude}

The attitude construct is a major focus of theory and research in the social and behavioral sciences (Ajzen, 2001). Attitude represents a summary evaluation of a psychological object captured along such dimensions as good-bad, harmful-beneficial, pleasant-unpleasant, and likable-unlikable. It is assumed that evaluative judgments are the result of cognitive processes: associations between the attitude object and valued attributes. However, Ajzen concludes in his review of attitude theory and research that some theorists have challenged this assumption, proposing that evaluations may also be controlled by affective processes. This predictor is included in the third model (Chapter 5) presented in this thesis.

\subsubsection{Methodology and Design}

In this thesis, the statistical technique structural equation modeling (SEM) is used to test the 
proposed models. The hypothesized models can thus be tested statistically in a simultaneous analysis of the entire "system" of potentially influential variables to determine the extent to which the model is consistent with the data. SEM can therefore reveal how critical factors interact in determining the intention to adopt nutrigenomics.

In most risk perception studies, the research methodology is predominantly based on crosssectional designs, presenting rather static (single-shot) representations of public perceptions or the attribution of trust and affect. The longitudinal process of perception formation and development are often neglected but could improve understanding of the stability of intentions to adopt new food technologies.

In this thesis the design of the studies was set up to develop a theoretical model that would reveal the most important psychological predictors and processes influencing the intention to adopt an emerging technology such as nutrigenomics. To this end, a range of approaches was used. The first model (presented in Chapter 3) utilized a path model aimed at including a broad range of predictors and was investigated using a survey design. The second model (Chapter 4) utilized a structural model investigating the role of trust, affect and cognition. A multi-group analysis was used to explore cross-national differences and therefore represented a test of the external validity of the model. The third model (Chapter 5), a structural model focusing on the role of involvement, affect and cognition, used multi-group analysis to replicate the model and test the utility of the model in another area of food technology, functional foods. Further, a longitudinal design was used to test the stability of this model over time.

\subsection{Outline}

The following chapters are organized as follows:

The first study described in Chapter 2 seeks to gain an overview of the public perception of research in the genomics field. This study systematically reviews the relevant literature from 1970 through 2006. It focuses on characteristics of the field and reveals an underdeveloped and fragmentized research field. Public perception research has investigated a broad range of relevant predictors of public perception of genomics, which are outlined in this chapter.

Chapter 3 builds on the results of Chapter 2 in a first attempt to model public reactions to gene-technology. A range of predictors identified in the literature review is included in a path model. Three determinants stood out as strong predictors of behavioral intention: affect, rational cognition and trust. In the study described in Chapter 4 , the aim was to test a model focused on these three psychological factors as potential predictors of intention to adopt personalized nutrition. A structural model was tested with multi-group analysis using data from The Netherlands and Australia. The model holds in both national settings, but for Australians intention is more determined by affective factors, for the Dutch by cognitive factors. Chapter 5 builds on the results of Chapter 4 and explores more in depth the relationship between the cognitive and affective processes in predicting individual intentions to adopt personalized 
nutrition. The predictor of personal involvement, already shown to be an important determinant in Chapter 2, is introduced as a predictor of these two processes. The model was replicated and validated six months later and found to be temporally stable. To test the utility of the model in another area of food technology, the model was tested and validated again for functional foods.

Finally, a reflection of the major findings and conclusions of the studies reported in this thesis are discussed in Chapter 6. Theoretical implications as well as practical implications for the introduction of nutrigenomics and future research efforts are described. 


\section{References}

Afman, L., \& Muller, M. (2006). Nutrigenomics: From molecular nutrition to prevention of disease. Journal of the American Dietetic Association, 106(4), 569-576.

Ajzen, I. (2001). Nature and operation of attitudes. Annual Review Of Psychology, 52, 2758.

Bauer, M. W., \& Gutteling, J. (2006). Issues Salience and Media Framing over 30 Years. In G. Gaskell \& M. W. Bauer (Eds.), Genomics and society: legal, ethical, and social dimensions (pp. 113-130). London: Earthscan.

Bord, R. J., \& O’Connor, R. E. (1990). Risk communication, knowledge and attitudes: Explaining reactions to a technology perceived as risky. Risk Analysis, 10(4), 499-505.

Bredahl, L. (2001). Determinants of consumer attitudes and purchase intentions with regard to genetically modified foods - results of a cross-national survey. Journal of Consumer Policy, 24(1), 23-61.

Brown, S. L., \& Eisenhardt, K. M. (1995). Product development: Past research, recent findings and future directions. Academy of Management Review, 20(2),343-376.

Burgess, M. M. (2003). Starting on the right foot: Public consultation to inform issue definition in genome policy (No. DEG 002). Vancouver: W. Maurice Young Centre for Applied Ethics.

Cooper, G. (1994). New products: The factors that drive success. International Marketing Review, 11(1), 60-76.

Chavez, A., \& de Chavez, M. M. (2003). Nutrigenomics in public health nutrition: shortterm perspectives. European Journal of Clinical Nutrition, 57, S97-S100.

Cuite, C. L., Aquino, H. L., \& Hallman, W. K. (2005). An empirical investigation of the role of knowledge in public opinion about GM food. International Journal of Biotechnology, 7(1-3), 178-194.

Cummings, E. E. “Since feeling is first.” E. E. Cummings: Complete Poems 1914-1962. Ed. George J. Firmage, New York: Liveright, 1991. 291.

Eng, T. R. (2004). Population health technologies: Emerging innovations for the health of the public. American Journal of Preventive Medicine, 26(3), 237-242.

Flynn, R., \& Bellaby P., (Eds) (2007) Risk and the Public Acceptance of New Technologies; Palgrave Macmillan: Basingstoke, Hampshire, UK. pp 41-66

Frewer, L. (2003). Societal issues and public attitudes towards genetically modified foods. Trends In Food Science \& Technology, 14(5-8), 319-332.

Frewer, L., Howard, C., \& Shephard, R. J. (1998). Understanding public attitudes to technology. Journal of Risk Research, 1(3), 221-235.

Frewer, L., Lassen, J., Kettlitz, B., Scholderer, J., Beekman, V., \& Berdal, K. G. (2004). Societal aspects of genetically modified foods. Food And Chemical Toxicology, 42(7), 1181-1193. 
Gaskell, G., Allum, N., Wagner, W., Kronberger, N., Torgersen, H., Hampel, J., et al. (2004). GM foods and the misperception of risk perception. Risk Analysis, 24(1), 185-194.

Grunert, K. G., Bredahl, L., \& Scholderer, J. (2003). Four questions on European consumers' attitudes toward the use of genetic modification in food production. Innovative Food Science and Emerging Technologies, 4(4), 435-445.

Gupta, A. K., \& Wilemon, D. J. (1990). Accelerating the development of technologybased new products. California Management Review, Winter, 24-44.

Gutteling, J. M. (2005). Mazur's hypothesis on technology controversy and media. International Journal of Public Opinion Research, 17(1), 23-41.

Hashim, I. B., Resurreccion, A. V., \& McWatters, K. H. (1995). Consumer acceptance of irradiated poultry. Poultry Science, 74, 1287-1294.

Henneman, L., Timmermans, D. R. M., \& van der Wal, G. (2004). Public experiences, knowledge and expectations about medical genetics and the use of genetic information. Community Genetics, 7(1), 33-43.

Henson, S., Annou, M., Cranfield, J., \& Ryks, J. (2008). Understanding consumer attitudes toward food technologies in Canada. Risk Analysis, 28(6), 1601-1617.

Horst, M., Kuttschreuter, M., \& Gutteling, J. M. (2007). Perceived usefulness, personal experiences, risk perception and trust as determinants of adoption of e-government services in The Netherlands. Computers in Human Behavior, 23(4), 1838-1852.

Johnson, B. T. (1994). Effects OfOutcome-Relevant Involvement And Prior Information On Persuasion. Journal Of Experimental Social Psychology, 30(6), 556-579.

Johnson, B. T., \& Eagly, A. H. (1989). Effects Of Involvement On Persuasion - A MetaAnalysis. Psychological Bulletin, 106(2), 290-314.

Kristensen, K., Osergaard, P.,\&Juhl,H. J. (1997). The Success and Failure of Product Development in the Danish Food Sector. MAPP Working Paper, Aarhus School of Business.

Lee, C. J., Scheufele, D. A., \& Lewenstein, B. V. (2005). Public attitudes toward emerging technologies - Examining the interactive effects of cognitions and affect on public attitudes toward nanotechnology. Science Communication, 27(2), 240-267.

Malone, J. W. (1990). Consumer willingness to purchase and pay more for potential benefits of irradiated fresh food products. Agribusiness, 6, 163-177.

Meijboom, F. L. B., Verweij, M. F., \& Brom, F. W. A. (2003). You eat what you are: Moral dimensions of diets tailored to one's genes. Journal Of Agricultural \& Environmental Ethics, 16(6), 557-568.

Moerbeek, H., \& Casimir, G. (2005). Gender differences in consumers' acceptance of genetically modified foods. International Journal of Consumer Studies, 29(4),308-318.

Muller, M., \& Kersten, S. (2003). Nutrigenomics: goals and strategies. Nature Reviews Genetics, 4(4), 315-322.

Park, H. S., Levine, T. R., Westerman, C. Y. K., Orfgen, T., \& Foregger, S. (2007). The effects of argument quality and involvement type on attitude formation and attitude change: A test of dual-process and social judgment predictions. Human Communication Research, 33(1), 81102.

Petty, R. E., Cacioppo, J. T., \& Schumann, D. (1983). Central and Peripheral Routes to Advertising Effectiveness - the Moderating Role of Involvement. Journal of Consumer Research, $10(2), 135-146$.

Rodriguez, M. B. S., Munoz, L.M.P., \& Casieri, R. C. (2007). Nutrigenomics, obesity and 
Public Health. Revista Espanola De Salud Publica, 81(5), 475-487.

Ronteltap,A., van Trijp, J.C.M., Renes, R.J.,\&Frewer,L.J.(2007). Consumer acceptance of technology-based food innovations: Lessons for the future of nutrigenomics. Appetite, 49(1), $1-17$.

Schenck, M. Fischer, A., Jacobsen, E. and Frewer, L.J. (2008). Patient and non-patient attitudes to different mitigation strategies for birch pollen allergies and Oral allergy syndrome. Health Risk and Society. 10(3), 263-282.

Shaw, A. (2002). "It just goes against the grain." Public understandings of genetically modified (GM) food in the UK. Public Understanding of Science, 11, 273-291.

Siegrist, M. (2000). The influence of trust and perceptions of risks and benefits on the acceptance of gene technology. Risk Analysis, 20 (2), 195-203.

Siegrist, M., \& Cvetkovich, G. (2000). Perception of hazards: The role of social trust and knowledge. Risk Analysis, 20(5), 713-719.

Slovic, P., Finucane, M. L., Peters, E., \& MacGregor, D. G. (2004). Risk as analysis and risk as feelings: Some thoughts about affect, reason, risk, and rationality. Risk Analysis, 24(2), 311322.

Slovic, P., Finucane, M. L., Peters, E., \& MacGregor, D. G. (2007). The affect heuristic. European Journal of Operational Research, 177(3), 1333-1352.

Slovic, P., Peters, E., Finucane, M. L., \& MacGregor, D. G. (2005). Affect, risk, and decision making. Health Psychology, 24(4), S35-S4O.

Townsend, E. (2006). Affective influences on risk perceptions of, and attitudes toward, genetically modified food. Journal of Risk Research, 9(2), 125-139.

Vandeberg, R. (2009). Nutrigenomics, Innovatie en Interactie? [nl]. Retrieved February 27, 2009, from http://www.rensvandeberg.com/?page_id=22

Verdurme, A., \& Viaene, J. (2003). Consumer beliefs and attitude towards genetically modified food: basis for segmentation and implications for communication. Agribusiness, 19(1), 91-113. 


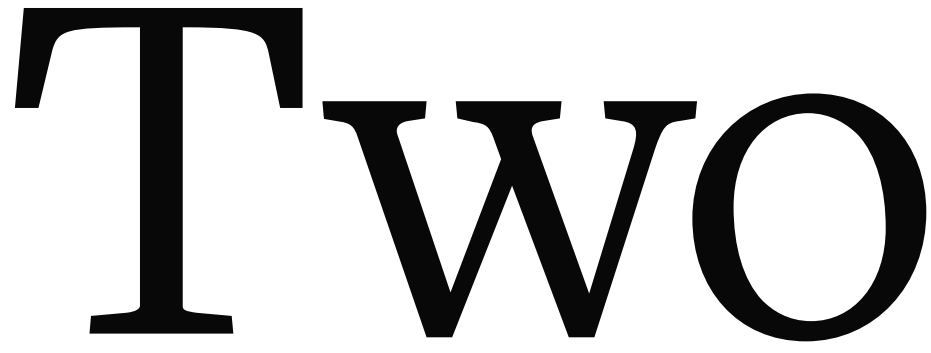

The Development of Public Risk Perception Research in the Genomics field - An Empirical Analysis of the Literature in the Field

Renske R. Pin Jan M. Gutteling

Science Communication. Prepublished December 29, 2008; DOI: $10.1177 / 1075547008327273$ 


\section{Abstract}

This article describes a meta-analysis that was conducted on the subjects of published academic research on the public perception of genomics. In total, 451 journal articles were analyzed, all published between 1970 and 2006 and sampled from the databases Web of Science and Scopus. Results indicate the increasing popularity of research on this topic in the last decade, which reflects the same curve as media coverage of the new technology. Many authors study the public perception of genomics, but only a small number are productive. There is a strong focus on food and agriculture genomics and a separate field of authors and journals for medical genomics. The authors make several recommendations for future developments in the public perception of genomics.

Keywords:

public perception; genomics; development; empirical content analysis; scientific literature 


\title{
Two
}

\author{
The Development of Public Risk Perception
}

\author{
Research in the Genomics Field - An Empirical \\ Analysis of the Literature in the Field
}

\subsection{Introduction}

The attitude of the public can make or break the development of new technologies. Genomicsthe study of genes and their functions-is rapidly creating access to valuable knowledge about humans, animals, plants, and other organisms. It is believed that the field will provide answers in biology, medicine, and industry as more applications of this knowledge become apparent. The aim of genomics in the domain of medical life sciences is to personalize medical care by basing treatments on a person's specific genetic makeup. Genomics research has enabled the identification of disease-related genes, which has subsequently led to the development of new genetic tests and the first notion of remedies for ailments that were previously untreatable. In another major development, nutrition-related applications such as genetically modified food and personalized nutrition have also emerged. Since the first memorandum on genetic manipulation in 1970, many scientists have studied the public perception of the more or less controversial applications of "red" and "green" genomics. ${ }^{1}$ However, a world map encompassing patterns of public perception is still lacking. This is a study of general trends in published scientific research related to the public perception of both medical and agri/plant aspects of genomics.

The life sciences business, integrating agrichemicals, GM foods and pharmaceuticals, became one of the industrial and scientific visions for the 21st century. Concurrently, however, European governments, the European Commission, and the European Parliament struggled and sometimes clashed over regulatory arrangements (Gaskell, Allum, et al., 2001). Based on recurring public opinion surveys in the EU, Gaskell and Bauer (2001, p.4) have named the period from 1996 to 1999 a "watershed" in the development of genomics. The public domain saw an outburst of media coverage from 1996 to 2001 (Bauer \& Gutteling, 2006), episodes of mobilization in protest against field trials of GM crops, consumer resistance to GM foods, supermarket boycotts, and, finally, in 1999, a moratorium on the commercial planting of GM crops in the European Union. Dolly, the sheep; Herman, the bull; and the genetically modified (GM) soy boycott stand as icons of these turbulent years. Bauer and Gutteling (2006, p. 121) identify the four phases of a global issue cycle of biotechnology in newspaper coverage: low early coverage until 1980, a steady increase between 1981 and 1995, the massive explosion of coverage from 1996 to 2001, and the beginning of the end of the attention cycle after 2002.

Although governments and interest groups legitimated their positions by claiming to represent public opinion, before the watershed, there were few-if any-attempts to find out what the European public actually thought (Gaskell, Allum, et al., 2001). Social pressures, and the political pressure that resulted, may explain the increasing proportion of the funding for genomics 
research that was assigned to the social sciences and intended to improve our understanding of the interaction between society and (especially green) genomics (Collins, Morgan, \& Patrinos, 2003). In turn, this rise in funding can explain the growing amount of research conducted on the public perception of genomics, which has possibly followed the same curve as the global issue cycle in media coverage of the new technology. In the early years, the field of ELSA (Ethical, Legal, and Social Aspects of genomics) was mainly dominated by ethicists. When applications such as functional food or gene therapy became a reality and were introduced into everyday life, social scientists entered the research domain (Condit, 2001). Perception studies focusing on the two different types of genomics (Frewer, Howard, \& Shepherd, 1997; Gaskell et al., 2000) have indicated that the European public is more positive toward medical genomics than agri/plant genomics (Bauer, 2005). During the 1990s, this red and green distinction began to dominate the media coverage of genomics, the public perception of the technology, and its regulation across Europe. In political reaction, GM products were banned from the European market. By 1999, the public viewed medical genomics much more favorably than agrifood genomics (Bauer, 2005). This may have been because of the clearer advantages of medical genomics for the public, which builds on favorable public opinion toward other substantial medical improvements in several fields. In the case of agrifood genomics, it has been less obvious who will benefit from the technology: the consumer, the farmer, or the multinational corporation that provides the agricultural products and pesticides (Gaskell et al., 2004). Uncertainty about possible long-term health risks may also have added fuel to the fire. The public perception of these two fields is quite different, and the negative public perception of GM food in the European Union (EU) has put particular negative pressure on the development of the green genomics field. A difference can also be seen between the United States and the European Union, as the red, medical applications of genomics are more heavily favored in Europe but have encountered resistance in the United States. Accordingly, social scientists, paying attention to the fields of green and red genomics, have been treating each differently.

Several studies have reviewed in detail specific conceptual issues or domains within the field (Finucane \& Holup, 2005; Grunert, 2002; Lusk, Jamal, Kurlander, Roucan, \& Taulman, 2005). But so far, a map of the world of the public risk perception of genomics research has not yet been established. Where do we stand as a research discipline? What issues have been covered so far, and which gaps within the research field can we identify? The value of such a map would be multifaceted. An analysis of the literature could identify the authors' home countries, which would then show trends in the focus of researchers in different states. Based on disparate developments in the political and the public domain, we would expect to find differences between EU and U.S. researchers' focus on red or green genomics perception issues. The study could yield insight into the parallels between the curve of attention in the media and the domain of public perception research. The study might also reveal trends in topics and keywords over time. This would raise conceptual questions about why certain issues or types of research are more frequent on one continent than on another. Might amount public controversy over specific types of genomics, with green and red more controversial in the European Union and the United States, respectively, be linked to the degree of perception research done on each field in each region? Furthermore, the study would identify important authors and journals, by giving insight into the breadth and depth of the research field. What can we learn from the research performed so far? What are the determinants of the public perception of genomics, and how far are we in 
understanding and modelling their influence?

The aim of this study is to give an overview of the development of research in the field of the public perception of genomics by systematically analyzing the field as it is represented in scientific journals. Similar systematic literature reviews have been conducted in other fields (Gurabardhi, Gutteling, \& Kuttschreuter, 2004; McComas, 2006; Zwier, Beentjes, \& Gutteling, 2006). In this study, we systematically analyze peer-reviewed articles published in the past 40 years and listed in the ISI Web of Science or Scopus database, by examining each article's abstract, keywords, title, authors, and journal information with four research questions in mind:

1. How can we characterize the literature on the public perception of genomics?

2. Do different trends exist in the literature on the public perception of red and green genomics?

3. What do scientific indicators tell us about the nature of published papers on the public perception of genomics?

4. So far, what are the specific determinants that influence public perception?

This last question is especially important, as it is important to integrate our insight into these determinants into the next step of our research, the systematical modelling the public perception of genomics.

\subsection{Method}

\subsubsection{Selection Procedure}

To gather references to published scientific articles on the public perception of genomics, we used the electronic online databases Web of Science (www.isiknowledge.com) and Scopus (www. scopus.com). Web of Science is a well-regarded database. According to the database publisher, it provides seamless access to current and retrospective multidisciplinary information from approximately 8,700 of the world's most prestigious, high-impact research journals of science, social science, and the arts and humanities (www.isinet.com). Scopus is a relatively new database that is quickly expanding to a size and level of importance comparable to that of Web of Science. We expected substantial coverage of the topic genomics in Scopus. According to its publisher, the Scopus database covers more than 12,850 academic journals of scientific, technical, medical, and social sciences literature, including 535 Open Access journals (www.scopus.com). The journals incorporated in these databases are selected for their peer-review systems, which are designed to improve the quality of their published articles. Web of Science has information extending back to 1988, and the Scopus database includes information from 1966 onward. We used these years as the starting points of our analysis. Our data was collected on May, 8, 2006, and coded afterward.

Both databases were searched using a search key developed by an independent information 
specialist from our university who had been briefed about the goal of our project. ${ }^{2}$ The search key reflects our focus on the risk perception of genomics.

We performed searches of article titles, abstracts, author keywords and indexed keywords ("Keywords Plus" in Web of Science and "Index terms [controlled terms]" in Scopus). Only journal articles are included in the final database used for analysis-specifically excluded are book reviews, editorials, conference proceedings, dissertations, books and book chapters. All search results (the raw data) were exported to the reference software Endnote and converted to an SPSS data file (Web of Science, $n=460$; Scopus, $n=799$ ). Both databases allow for exporting a wealth of descriptive information about each article, including its title, author(s), publication year, journal title, country of origin, citation index, keywords, and full abstract. This information is intended to inform potential readers about the crucial conceptual and methodological aspects of a study, and it usually prompts a researcher's decision to use or not to use an article. Of course, this can cause issues of misrepresentation, for example, when the quality of an abstract is not consequently monitored by a journal. The use of modern online search databases such as Web of Science and Scopus greatly increases the importance of adequate titling, correct keyword usage, and adequately developed abstracts. Our conclusion is that for the purpose of our study, this combination of title, keywords and abstract is sufficient.

At this stage, we removed from the analysis all articles that fell within the following categories:

- $\quad$ Double references (sources available in both databases, removed one of the references) $(n=350)$,

- $\quad$ Nonresearch articles (book reviews, editorials, etc.) $(n=28)$,

- $\quad$ Nongenomics-related articles (e.g., heredity, racism) $(n=66)$,

- Articles not related to public perception (e.g., education, other actors) $(n=364)$.

The final number of articles produced through this process was 451, of which 206 were derived singularly from Scopus, 50 from Web of Science, and 195 from both databases. This confirmed our assumption that Scopus has emerged as an important source for relevant peer-reviewed research articles on the public perception of genomics.

\subsubsection{Coding}

For all the articles in our sample, we coded from the abstracts and reference information, the descriptive variables available in the Web of Science and Scopus databases, and seven interpretativevariables that required coderjudgment. Ourfocus on thesevariablesis notintended to provide an extended conceptual analysis, as this has already been done (e.g., Finucane \& Holup, 2005; Ronteltap, van Trijp, Renes, \& Frewer, 2007; Verdurme \& Viaene, 2001), but it will offer the information in order to provide an overall picture of the research field. In this article, we report the following descriptive variables for each article in our sample: author name(s) and initials, year of publication, disciplinary affiliation of first author, country of first author, publication journal, number of times others have cited the particular article, and keywords. We recoded the author/publisher keywords available in the databases into a set of five keywords per article. Some 
references listed only author/publisher keywords, while others had both sets. Accordingly, when one set of keywords was available in the database, that one was used; conversely, when both sets were available, only author keywords were used. Keywords were categorised and aggregated. We distinguished nine categories of keywords. The category "application field" referred to the field of application of genomics and encompassed such keywords as biotechnology, gene-technology, GMOs, GM food, and cloning. All keywords relating to perception, attitudes, acceptance, and public opinion were put in the category "attitudes and perceptions." The category "factors and determinants" included keywords referring to benefit, risk, trust, knowledge, behavior, willingness to pay, and so forth. The category "research method" comprised keywords relating to the method used in a study, "location" to the country or continent in which the research had taken place, and "subjects" to the group being studied. Coded as "Ethical Aspects" were keywords relating to moral and ethical facets of genomics. Keywords coded as "Medical" referred to specific medical issues and terms, for example, diseases, syndromes, and medications. Finally, the category "other aspects" referred to keywords that did not fit into any of the above categories. This was true, for instance, of keywords referring to communication, policy, legal issues or safety.

In this research, eight interpretative variables-namely, research type, the research method used, the genomics topic covered, and the measurement of attitudes, (perceived) risks, (perceived) benefits, ethical aspects, and other determinants-were coded by one observer. The interpretative variables were coded according to the following classifications.

The research type was coded as quantitative, qualitative, or a combination of both. We defined quantitativeresearch as that based on thenumerical representation of observations and statistical analysis, such as surveys or experiments. We defined qualitative research as that involving detailed, verbal description of characteristics, cases, and settings: in-depth interviewing, focus groups or discourse analyses, for example. Some studies combined both types of research.

The research method used was coded as follows: survey/interviews, desk research/narrative essays, focus groups, experiments, reviews, content analysis/media analysis, mixed methods, or other methods.

The genomics topic covered was coded as unspecified, red genomics, green genomics or a combination and/or comparison of different genomics types. Red genomics includes gene therapy, genetic testing, pharmaceuticals and medicines, reproduction and in vitro fertilization, human genetics, human genome, and xeno-transplantation. Green genomics includes agriculture, food genomics, plant breeding, animal breeding, GMO releases, environmental risk, GM foods, and biodiversity (Bauer, 2005). The category of unspecified genomics was coded for studies on genomics in general. Studies on other kinds of genomics- such as white (industrial) genomics-were coded in the last category, along with combinations or comparisons of different kinds of genomics.

Five different variables were coded as yes/no for abstracts including or omitting the measurement of attitudes, (perceived) risks, (perceived) benefits, ethical and/or moral aspects and other determinants that affect the public perception of genomics. 
Reliability (the stability of the observer) was calculated after a second coder recoded a random sample of 70 articles (15\%) from the total sample of 451 articles. Agreement among the coders was calculated and varied between $71 \%$ and $89 \%$ for six of the variables, which is satisfactory (see Appendix 1). Two variables, research type and research method, had a less satisfying rate of agreement (both 60\%). This was caused by vagueness about the performed (empirical) research in a large portion of the abstracts. ${ }^{3}$

\subsection{Results}

\subsubsection{Descriptive Analyses}

\section{Sample Characteristics}

Figure 1 presents the distribution of articles over the years from 1970 through 2006 (number of relevant articles for 2006 is estimated at 66, based on 22 articles published during the first four months of the year). We grouped the articles into three periods as a measure of development.

Figure 1

Distribution of Articles in our Sample Over the Years 1970-2006 $(n=451)^{*}$

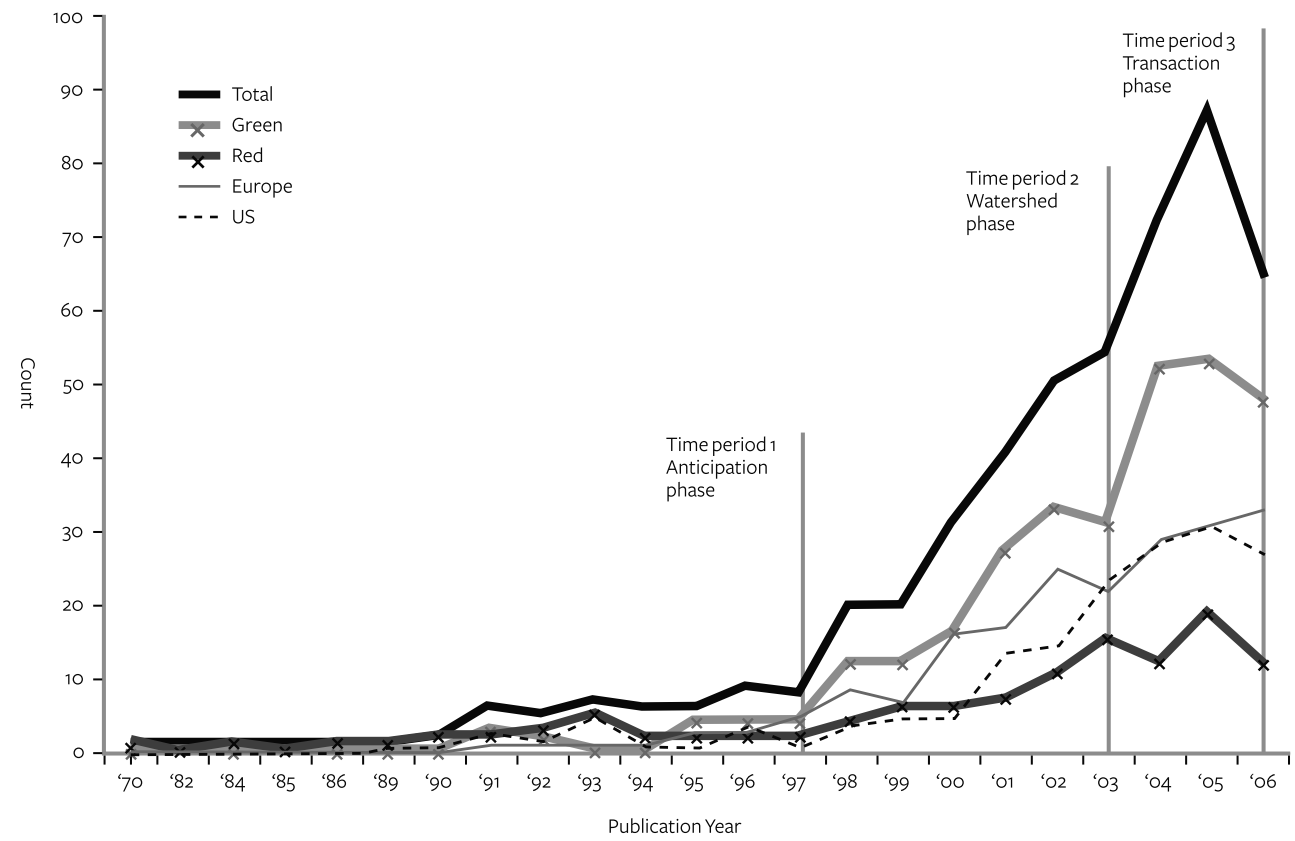

*Estimated number of relevant articles in 2006: 66 (based on 22 articles in the first four months). 
The first period is from 1970 until 1997 (27years, $n=55,12.2 \%$ of sample). These are the earlyyears, in which few articles were published. We refer to this as the anticipation phase. Near its close, significant events took place: GM soy was introduced to the European market (Autumn 1996) and cloned sheep Dolly was presented to the public (February 1997). Bauer and Gaskell (2001, p.4) refer to this point in time as the "watershed years". At this point, genomics became a rapidlygrowing research issue. The second time period, 1998 through 2003 (six years, $n=215,47.7 \%$ of sample), is referred to as the watershed period. In the third period, 2004 through 2006 (three years, $n=181,40.1 \%$ of sample), genomics moved to the transaction level, with more applications becoming available in everyday life. Accordingly, genomics became a more accessible topic for the public, which began to participate more significantly in (survey) research. Figure 1 indicates stronger research growth during this third period, though a turning point was reached in 2006, with the predicted number of relevant articles less than that counted in 2004 and 2005.

In looking at the development of research specifically on the public perception of red versus green genomics (Figure 1), we see a similar trend during the first period. However, during the second period, the volume of research on green genomics grew much faster than did the amount of research on red genomics. Similarly, during the third period, three times as much research was conducted on green genomics than on red genomics. When comparing the research that took place in the United States and Canada with that taking place in Europe, we see that Europe produced more studies during the second period. We also see a similar trend in the first and the third period. It is particularly striking that in 2006 , the total amount of US research done on both red and green genomics in the United States dropped-whereas in Europe, the overall quantity of research done was still rising.

\section{Authorship}

To measure the visibility of an author, we used two indicators: frequency of publication and frequency of citation. The pressure in universities to publish, specifically in peer-reviewed journals, is rising; at the same time, increasing importance is attached to citation indices. Each of these indicators raises objections as a norm for the actual visibility of an author. Therefore, we have used both to define comparable units within the overall picture of public perception research. A list of all authors in the sample was compiled. From the 451 articles, 875 unique authors were counted. The result is a mean of .52 articles written per author. We identified 38 authors with four or more articles in the sample, 114 with two or three articles, and 723 incidental authors with only one article. In Table 1 we listed the 12 most productive authors (those with six or more articles in the sample).

The 12 most productive authors were counted 90 times and together published 69 articles. Of these articles, 41 (59\%) described studies on green genomics. If we compare the different genomics fields, we see that the role of these productive authors is somewhat more dominant in green genomics (22\% of all green studies) than in red genomics (11\% of all red studies). While from 1970 through $1997,29 \%$ of the articles in the sample were written by the 12 most productive authors, their role becomes less dominant from 1998 through 2006. This would be expected because more researchers began work in this area during this period. 
Table 1

12 Most Productive Authors on Public Perception of Genomics in the Sample

\begin{tabular}{|c|c|c|c|c|c|c|c|c|c|c|c|}
\hline \multirow[b]{2}{*}{ Author* } & \multirow[b]{2}{*}{$\begin{array}{r}\text { Articles } \\
\text { in } \\
\text { sample }\end{array}$} & \multirow[b]{2}{*}{$\begin{array}{l}\text { As first } \\
\text { author }\end{array}$} & \multirow[b]{2}{*}{$\begin{array}{r}\text { Country of } \\
\text { author }\end{array}$} & \multirow[b]{2}{*}{$\begin{array}{l}\text { Times } \\
\text { cited }\end{array}$} & \multicolumn{4}{|c|}{ Type of Genomics } & \multicolumn{3}{|c|}{ Period } \\
\hline & & & & & $\begin{array}{r}\text { Un- } \\
\text { specified }\end{array}$ & Green & Red & $\begin{array}{r}\text { Other } \\
\text { and } \\
\text { Combi- } \\
\text { nation }\end{array}$ & $\begin{array}{r}1970- \\
1997\end{array}$ & $\begin{array}{l}1998- \\
2003\end{array}$ & $\begin{array}{r}2004- \\
2006\end{array}$ \\
\hline $\begin{array}{l}\text { Frewer, } \\
\text { L.J. }\end{array}$ & 18 & 12 & $\begin{array}{r}\text { UK/ } \\
\text { The Neth. }\end{array}$ & 229 & $\circ$ & 17 & $\circ$ & 1 & 4 & 11 & 3 \\
\hline $\begin{array}{l}\text { Lusk, } \\
\text { J.L. }\end{array}$ & 9 & 6 & US & 53 & ○ & 9 & $\circ$ & ० & o & 3 & 6 \\
\hline $\begin{array}{l}\text { Grunert, } \\
\text { K.G. }\end{array}$ & 7 & 5 & Denmark & 49 & $\circ$ & 7 & $\circ$ & $\circ$ & o & 5 & 2 \\
\hline $\begin{array}{l}\text { Condit, } \\
\text { C. }\end{array}$ & 7 & 1 & US & 39 & 2 & $\circ$ & 5 & $\circ$ & o & 2 & 5 \\
\hline $\begin{array}{l}\text { Gaskell, } \\
\text { G. }\end{array}$ & 6 & 5 & UK & 192 & $\circ$ & 3 & ○ & 3 & o & 4 & 2 \\
\hline $\begin{array}{l}\text { Bauer, } \\
\text { M.W. }\end{array}$ & 6 & 3 & UK & 166 & 2 & 1 & $\circ$ & 3 & o & 5 & 1 \\
\hline $\begin{array}{l}\text { Howard, } \\
\text { C. }\end{array}$ & 7 & ○ & UK & 139 & ० & 5 & $\circ$ & 2 & 4 & 3 & ० \\
\hline $\begin{array}{l}\text { Macer, } \\
\text { D.R.J. }\end{array}$ & 6 & 4 & Japan & 42 & 3 & ० & 3 & $\circ$ & 2 & 4 & ○ \\
\hline $\begin{array}{l}\text { House, } \\
\text { L.O. }\end{array}$ & 6 & 1 & US & 24 & o & 6 & ० & ० & o & 1 & 5 \\
\hline $\begin{array}{l}\text { McCluskey, } \\
\text { J.J. }\end{array}$ & 6 & 1 & US & 22 & 1 & 5 & ० & $\circ$ & o & 2 & 4 \\
\hline $\begin{array}{l}\text { Wertz, } \\
\text { D.C. }\end{array}$ & 6 & 3 & US & 36 & 1 & o & 4 & 1 & 2 & 4 & ० \\
\hline $\begin{array}{l}\text { Shepherd, } \\
\text { R. }\end{array}$ & 6 & o & UK & 132 & $\circ$ & 5 & ○ & 1 & 4 & 2 & o \\
\hline Column total & 90 & 41 & & 1081 & 9 & 58 & 12 & 11 & 16 & 46 & 28 \\
\hline \multirow{2}{*}{$\begin{array}{l}\text { Comparison } \\
\text { base }\end{array}$} & 451 & 90 & & 1918 & 58 & 269 & 107 & 17 & 55 & 215 & 181 \\
\hline & $20 \%$ & $46 \%$ & & $56 \%$ & $16 \%$ & $22 \%$ & $11 \%$ & $65 \%$ & $29 \%$ & $21 \%$ & $16 \%$ \\
\hline
\end{tabular}

*Authors sorted by number of articles in sample, number of times as first author and number of times cited. 
In total, of the 12 most productive authors, six originate from Western Europe and five from the United States, which indicates the dominance of scientists from these parts of the world in the field of public perception research on genomics. These results are reflected in Table 2, which presents the breakdown of the first authors' countries of origin. Of all authors with four or more articles in our sample, $59 \%$ originate from Western Europe and $29 \%$ from the United States. The origins of the other authors are more equally distributed among Western Europe and the United States. During the period from 1970 through 1997, most authors came from other areas than the United States or Western Europe. Between 1998 and 2003, 45\% of the authors came from Europe. In the period from 2004 through 2006 , almost equal proportions of the articles were based in the United States and Western Europe. In looking at the distribution of data by type of genomics, we can see that authors from the United States have indeed focused more on red genomics, while in Western Europe green genomics is featured more strongly. Of all perception studies on green genomics, $47 \%$ have been done by European researchers, while $47 \%$ of all studies on red genomics have been done by researchers from the United States and Canada.

Table 2

Breakdown of First Author's Country of Origin by Type of Genomics, Publication Period and Authorship

\begin{tabular}{|c|c|c|c|c|c|c|c|c|c|c|c|}
\hline & \multirow{2}{*}{$\begin{array}{l}\text { Total in } \\
\text { Sample }\end{array}$} & \multicolumn{4}{|c|}{ Type of Genomics } & \multicolumn{3}{|c|}{ Period } & \multicolumn{3}{|c|}{ Authorship } \\
\hline & & $\begin{array}{r}\text { Un- } \\
\text { specified }\end{array}$ & Green & Red & $\begin{array}{r}\text { Other } \\
\text { and } \\
\text { Combi- } \\
\text { nation }\end{array}$ & $\begin{array}{r}1970- \\
1997\end{array}$ & $\begin{array}{l}1998- \\
2003\end{array}$ & $\begin{array}{r}2004- \\
2006\end{array}$ & $\geq 4$ & $20 r 3$ & 1 \\
\hline $\begin{array}{l}\text { Western } \\
\text { Europe, } \\
\text { including } \\
\text { United } \\
\text { Kingdom }\end{array}$ & $\begin{array}{r}182 \\
(40 \%)\end{array}$ & $\begin{array}{r}20 \\
(35 \%)\end{array}$ & $\begin{array}{r}125 \\
(47 \%)\end{array}$ & $\begin{array}{r}30 \\
(28 \%)\end{array}$ & $\begin{array}{r}7 \\
(41 \%)\end{array}$ & $\begin{array}{r}15 \\
(27 \%)\end{array}$ & $\begin{array}{r}96 \\
(45 \%)\end{array}$ & $\begin{array}{r}71 \\
(39 \%)\end{array}$ & $\begin{array}{r}47 \\
(59 \%)\end{array}$ & $\begin{array}{r}43 \\
(39 \%)\end{array}$ & $\begin{array}{r}93 \\
(35 \%)\end{array}$ \\
\hline $\begin{array}{l}\text { United States } \\
\text { and Canada }\end{array}$ & $\begin{array}{r}155 \\
(34 \%)\end{array}$ & $\begin{array}{r}19 \\
(33 \%)\end{array}$ & $\begin{array}{r}81 \\
(30 \%)\end{array}$ & $\begin{array}{r}50 \\
(47 \%)\end{array}$ & $\begin{array}{r}5 \\
(29 \%)\end{array}$ & $\begin{array}{r}19 \\
(35 \%)\end{array}$ & $\begin{array}{r}67 \\
(31 \%)\end{array}$ & $\begin{array}{r}69 \\
(38 \%)\end{array}$ & $\begin{array}{r}23 \\
(29 \%)\end{array}$ & $\begin{array}{r}38 \\
(35 \%)\end{array}$ & $\begin{array}{r}94 \\
(36 \%)\end{array}$ \\
\hline $\begin{array}{l}\text { Other } \\
\text { areas, incl. } \\
\text { Australia, } \\
\text { New Zealand, } \\
\text { Central \& } \\
\text { Latin America } \\
\text { and Japan }\end{array}$ & $\begin{array}{r}114 \\
(25 \%)\end{array}$ & $\begin{array}{r}19 \\
(33 \%)\end{array}$ & $\begin{array}{r}63 \\
(23 \%)\end{array}$ & $\begin{array}{r}27 \\
(25 \%)\end{array}$ & $\begin{array}{r}5 \\
(29 \%)\end{array}$ & $\begin{array}{r}21 \\
(38 \%)\end{array}$ & $\begin{array}{r}52 \\
(24 \%)\end{array}$ & $\begin{array}{r}41 \\
(23 \%)\end{array}$ & $\begin{array}{r}10 \\
(13 \%)\end{array}$ & $\begin{array}{r}28 \\
(26 \%)\end{array}$ & $\begin{array}{r}75 \\
(29 \%)\end{array}$ \\
\hline Totalsample & $\begin{array}{r}451 \\
(100 \%)\end{array}$ & $\begin{array}{r}58 \\
(100 \%)\end{array}$ & $\begin{array}{r}269 \\
100 \%)\end{array}$ & $\begin{array}{r}107 \\
(100 \%)\end{array}$ & $\begin{array}{r}17 \\
(100 \%)\end{array}$ & $\begin{array}{r}55 \\
(100 \%)\end{array}$ & $\begin{array}{r}215 \\
(100 \%)\end{array}$ & $\begin{array}{r}181 \\
(100 \%)\end{array}$ & $\begin{array}{r}80 \\
(100 \%)\end{array}$ & $\begin{array}{r}109 \\
(100 \%)\end{array}$ & $\begin{array}{r}261 \\
(100 \%)\end{array}$ \\
\hline
\end{tabular}

Most Cited Articles

In our database, we coded the number of citations for each article (as of the date of selection). Citation by other scientists is an indicator of the visibility of an individual article and its author(s). In total, the 450 articles in the database (no citation index was available in one case) had been cited 2045 times, which makes 4.54 citations per article on average. Of the articles, 181 (40\%) had not been cited at all. Thirteen articles had been cited more than 25 times (see Appendix 2). 
These 13 articles gathered 685 citations (33\% of the total citation sample), which underlines their importance to the domain of the public perception of genomics. All articles on this list of most cited articles were published between 1993 and 2001.

There is some bias in this analysis due to the articles' citation indices are calculated from their citation within the database from which they originate. Because Scopus carries more articles, we must expect these articles to have higher citation indices than the ones derived from Web of Science. Therefore, they cannot fairly be compared (although of the 13 most cited articles 5, originate from Web of Science; see Appendix 2).

It is remarkable that only four of the listed articles were (co)authored by one or more of our 12 most productive authors (as notated in Table 1). Clearly, an author's productivity within the field does not necessarily guarantee a high number of citations. One explanation for this can be found in the fact that of the four articles on the most cited list, which are written by one of the 12 most productive authors, only one focuses on red genomics, which is a much broader field resulting in higher citation indices. On the other hand, the list includes the two papers by Gaskell $(1999,2000)$ covering the results of the extensive Eurobarometer surveys, as well as two studies by Frewer $(1997,2001)$ on the public perception of genetically modified foods. Heavily cited studies by Wynne (2001), Sjöberg (2001) and Bredahl (1999) focus on the same topic. First authors who have a high frequency of publication (with four or more articles in our database) have a significantly higher citation index (with a mean of 8.99 times cited) than those authors who have published either one, two to three articles (with means of 3.73 and 3.27 times cited, respectively).

\section{Journals That Publish Articles on Public Perception of Genomics}

Reflecting the degree of fragmentation within this field, the 451 articles in our sample were published in 250 journals, of which 179 (72\%) only published one article on the public perception of genomics. When listing the 10 most relevant journals (see Appendix 3), we see that these journals published between 7 and 23 articles on the topic during the period from 1970 through 2006-approximately $25 \%$ of the total sample. The six journals at the top of the list mainly focused on green genomics. Only Community Genetics, at the bottom, features a focus on red genomics. Of the 114 articles published in the1o most relevant journals, 58 (51\%) were published between 2004 and 2006. In looking at the share of these 10 most relevant journals in the articles published during the three periods, we find that they in fact increased their share from $7 \%$ to $32 \%$. Of all the articles written by the most productive authors, $45 \%$ were published in the 10 most relevant journals, which indicates that these journals are important to the field of the public perception of genomics.

\subsubsection{Substantive Analysis: Conceptual and Methodological}

Focus of the Studies

All articles were coded to reflect whether the studies they describe measured attitudes, (perceived) benefits, (perceived) risks, ethical aspects, and/or other determinants of public perception and attitudes toward genomics (see Table 3). Fifty-two percent of the article abstracts mention attitude measurement. In comparing the samples of articles covering studies 
on red and green genomics, we see that $45 \%$ of the abstracts in both subsamples mention attitude measurement. Authors who have been more productive (with four or more articles) have tended to focus more on attitude measurement than other authors have done. Risk perception is more often measured than benefit perception, especially within studies focussing on green genomics. Of the more productive authors, $40 \%$ have measured risk perception, while $34 \%$ have measured benefit perception. Over time, the number of studies addressing risk and benefit perception has increased, while the focus on ethical aspects of genomics has been decreasing. Other determinants addressed in this sample as influencing the public perception of genomics appear in 177 (39\%) of the studies. These references include determinants such as trust, knowledge, beliefs, interest, concern, affect, demographics, worldview, lifestyle, religion, and-in the case of green genomics - the type of manufacturing process employed, along with the brand, price, product information and labelling. In an extension of our analysis, we counted the articles that mentioned systematic research on the determinants of public perception or on modelling the sociopsychological process of forming the public perception of genomics and its determinants. We identified 36 articles (8\%) that fit this description. We also counted the abstracts that described studies as based on a theoretical framework. This group numbered 45 articles (10\%).

Table 3

Number of Abstracts Mentioning Measurement of Attitudes, Benefit Perception, Risk Perception, Ethical

Aspects, and Other Determinants of Perception Frequencies Within Total, per Type of Genomics, per Period and Authorship ${ }^{\mathrm{a}}$

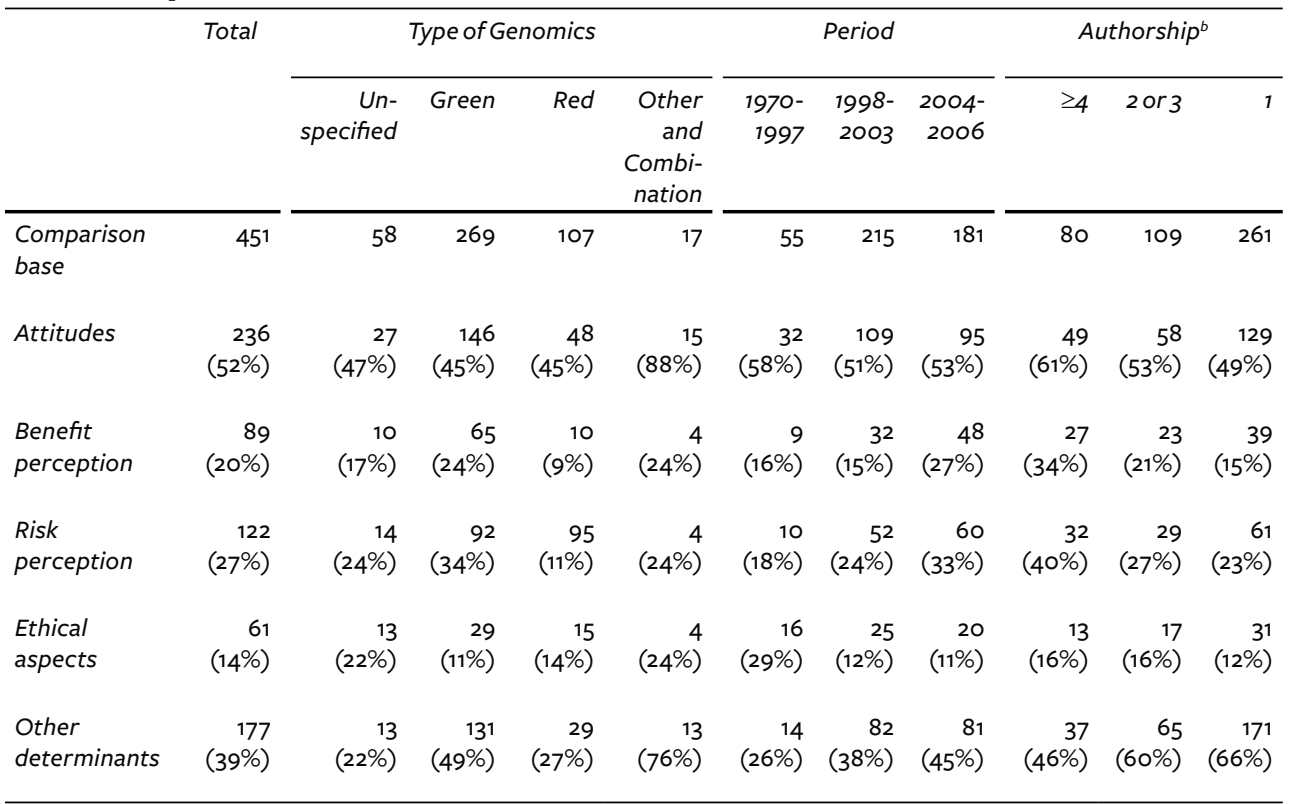

a. In parentheses is measure's percentage of column's comparison base; categories are nonexclusive.

b. Author of one article is unknown. 
Table 4

Numbers of Articles, Keywords, Mean Number of Keywords per Article, and Frequency Distribution of Keyword Categories

\begin{tabular}{|c|c|c|c|c|c|c|c|c|c|c|c|}
\hline & \multirow{2}{*}{$\begin{array}{c}\text { Total } \\
\text { sample }\end{array}$} & \multicolumn{4}{|c|}{ Type of Genomics } & \multicolumn{3}{|c|}{ Period } & \multicolumn{3}{|c|}{ Authorship } \\
\hline & & $\begin{array}{r}\text { Un- } \\
\text { specified }\end{array}$ & Green & Red & $\begin{array}{r}\text { Other } \\
\text { and } \\
\text { Combi- } \\
\text { nation } \\
\end{array}$ & $\begin{array}{r}1970- \\
1997\end{array}$ & $\begin{array}{l}1998- \\
2003\end{array}$ & $\begin{array}{r}2004- \\
2006\end{array}$ & $\geq 4$ & 2 or 3 & 1 \\
\hline $\begin{array}{l}\text { Number of } \\
\text { articles with } \\
\text { keywords }\end{array}$ & 413 & 52 & 244 & 102 & 15 & 47 & 194 & 172 & 70 & 102 & 240 \\
\hline $\begin{array}{l}\text { Total number } \\
\text { of keywords }\end{array}$ & $\begin{array}{r}1793 \\
(100 \%)\end{array}$ & $\begin{array}{r}231 \\
(100 \%)\end{array}$ & $\begin{array}{r}1040 \\
(100 \%)\end{array}$ & $\begin{array}{r}459 \\
(100 \%)\end{array}$ & $\begin{array}{r}63 \\
(100 \%)\end{array}$ & $\begin{array}{r}199 \\
(100 \%)\end{array}$ & $\begin{array}{r}837 \\
(100 \%)\end{array}$ & $\begin{array}{r}757 \\
(100 \%)\end{array}$ & $\begin{array}{r}297 \\
(100 \%)\end{array}$ & $\begin{array}{r}445 \\
(100 \%)\end{array}$ & $\begin{array}{r}1046 \\
(100 \%)\end{array}$ \\
\hline $\begin{array}{l}\text { Mean number } \\
\text { of keywords } \\
\text { perarticle }\end{array}$ & 4.34 & 4.44 & 4.26 & 4.50 & 4.20 & 4.23 & 4.31 & 4.40 & 4.24 & 4.36 & 4.36 \\
\hline $\begin{array}{l}\text { Application } \\
\text { field }\end{array}$ & $\begin{array}{r}553 \\
(31 \%)\end{array}$ & $\begin{array}{r}62 \\
(27 \%)\end{array}$ & $\begin{array}{r}338 \\
(33 \%)\end{array}$ & $\begin{array}{r}130 \\
(28 \%)\end{array}$ & $\begin{array}{r}23 \\
(37 \%)\end{array}$ & $\begin{array}{r}60 \\
(30 \%)\end{array}$ & $\begin{array}{r}282 \\
(34 \%)\end{array}$ & $\begin{array}{r}211 \\
(28 \%)\end{array}$ & $\begin{array}{r}85 \\
(29 \%)\end{array}$ & $\begin{array}{r}130 \\
(29 \%)\end{array}$ & $\begin{array}{r}337 \\
(32 \%)\end{array}$ \\
\hline $\begin{array}{l}\text { Attitudes and } \\
\text { perceptions }\end{array}$ & $\begin{array}{r}217 \\
(12 \%)\end{array}$ & $\begin{array}{r}32 \\
(14 \%)\end{array}$ & $\begin{array}{r}125 \\
(12 \%)\end{array}$ & $\begin{array}{r}51 \\
(11 \%)\end{array}$ & $\begin{array}{r}9 \\
(14 \%)\end{array}$ & $\begin{array}{r}33 \\
(17 \%)\end{array}$ & $\begin{array}{r}102 \\
(12 \%)\end{array}$ & $\begin{array}{r}82 \\
(11 \%)\end{array}$ & $\begin{array}{r}40 \\
(14 \%)\end{array}$ & $\begin{array}{r}58 \\
(13 \%)\end{array}$ & $\begin{array}{r}118 \\
(11 \%)\end{array}$ \\
\hline $\begin{array}{l}\text { Factors and } \\
\text { determinants }\end{array}$ & $\begin{array}{r}215 \\
(12 \%)\end{array}$ & $\begin{array}{r}23 \\
(10 \%)\end{array}$ & $\begin{array}{r}161 \\
(16 \%)\end{array}$ & $\begin{array}{r}23 \\
(4 \%)\end{array}$ & $\begin{array}{r}8 \\
(13 \%)\end{array}$ & $\begin{array}{r}13 \\
(7 \%)\end{array}$ & $\begin{array}{r}82 \\
(10 \%)\end{array}$ & $\begin{array}{r}120 \\
(16 \%)\end{array}$ & $\begin{array}{r}68 \\
(23 \%)\end{array}$ & $\begin{array}{r}42 \\
(9 \%)\end{array}$ & $\begin{array}{r}105 \\
(10 \%)\end{array}$ \\
\hline $\begin{array}{l}\text { Research } \\
\text { method }\end{array}$ & $\begin{array}{r}86 \\
(5 \%)\end{array}$ & $\begin{array}{r}6 \\
(3 \%)\end{array}$ & $\begin{array}{r}60 \\
(6 \%)\end{array}$ & $\begin{array}{r}15 \\
(3 \%)\end{array}$ & $\begin{array}{r}5 \\
(8 \%)^{2}\end{array}$ & $\begin{array}{r}3 \\
(2 \%)^{2}\end{array}$ & $\begin{array}{r}36 \\
(4 \%)\end{array}$ & $\begin{array}{r}47 \\
(6 \%)\end{array}$ & $\begin{array}{r}12 \\
(4 \%)\end{array}$ & $\begin{array}{r}31 \\
(7 \%)\end{array}$ & $\begin{array}{r}43 \\
(4 \%)\end{array}$ \\
\hline Location & $\begin{array}{r}65 \\
(4 \%)\end{array}$ & $\begin{array}{r}10 \\
(4 \%)\end{array}$ & $\begin{array}{r}44 \\
(4 \%)\end{array}$ & $\begin{array}{r}10 \\
(2 \%)\end{array}$ & $\begin{array}{r}1 \\
(2 \%)\end{array}$ & $\begin{array}{r}6 \\
(3 \%)\end{array}$ & $\begin{array}{r}23 \\
(3 \%)\end{array}$ & $\begin{array}{r}36 \\
(5 \%)\end{array}$ & $\begin{array}{r}12 \\
(4 \%)\end{array}$ & $\begin{array}{r}16 \\
(4 \%)\end{array}$ & $\begin{array}{r}36 \\
(3 \%)\end{array}$ \\
\hline Subjects & $\begin{array}{r}68 \\
(4 \%)\end{array}$ & $\begin{array}{r}12 \\
(5 \%)\end{array}$ & $\begin{array}{r}25 \\
(2 \%)\end{array}$ & $\begin{array}{r}30 \\
(7 \%)\end{array}$ & $(2 \%)^{1}$ & $\begin{array}{r}9 \\
(5 \%)\end{array}$ & $\begin{array}{r}31 \\
(4 \%)\end{array}$ & $\begin{array}{r}28 \\
(4 \%)\end{array}$ & $\begin{array}{r}6 \\
(2 \%)\end{array}$ & $\begin{array}{r}16 \\
(4 \%)\end{array}$ & $\begin{array}{r}44 \\
(4 \%)\end{array}$ \\
\hline $\begin{array}{l}\text { Ethical } \\
\text { aspects }\end{array}$ & $\begin{array}{r}49 \\
(3 \%)\end{array}$ & $\begin{array}{r}12 \\
(5 \%)\end{array}$ & $\begin{array}{r}14 \\
(1 \%)\end{array}$ & $\begin{array}{r}19 \\
(4 \%)\end{array}$ & $\begin{array}{r}4 \\
(6 \%)\end{array}$ & $\begin{array}{r}8 \\
(4 \%)\end{array}$ & $\begin{array}{r}22 \\
(3 \%)\end{array}$ & $\begin{array}{r}19 \\
(3 \%)\end{array}$ & $\begin{array}{r}5 \\
(2 \%)\end{array}$ & $\begin{array}{r}12 \\
(3 \%)\end{array}$ & $\begin{array}{r}32 \\
(3 \%)\end{array}$ \\
\hline Medical & $\begin{array}{r}60 \\
(3 \%)\end{array}$ & $\begin{array}{r}2 \\
(1 \%)^{2}\end{array}$ & $\begin{array}{r}8 \\
(1 \%)\end{array}$ & $\begin{array}{r}50 \\
(11 \%)\end{array}$ & $\begin{array}{r}0 \\
(0 \%)\end{array}$ & $\begin{array}{r}18 \\
(9 \%)\end{array}$ & $\begin{array}{r}26 \\
(3 \%)\end{array}$ & $\begin{array}{r}16 \\
(2 \%)\end{array}$ & $\begin{array}{r}5 \\
(2 \%)\end{array}$ & $\begin{array}{r}11 \\
(3 \%)\end{array}$ & $\begin{array}{r}44 \\
(4 \%)\end{array}$ \\
\hline $\begin{array}{l}\text { Other } \\
\text { aspects }\end{array}$ & $\begin{array}{r}480 \\
(27 \%)\end{array}$ & $\begin{array}{r}72 \\
(31 \%)\end{array}$ & $\begin{array}{r}265 \\
(26 \%)\end{array}$ & $\begin{array}{r}131 \\
(29 \%)\end{array}$ & $\begin{array}{r}12 \\
(19 \%)\end{array}$ & $\begin{array}{r}49 \\
(25 \%)\end{array}$ & $\begin{array}{r}233 \\
(28 \%)\end{array}$ & $\begin{array}{r}198 \\
(26 \%)\end{array}$ & $\begin{array}{r}64 \\
(22 \%)\end{array}$ & $\begin{array}{r}129 \\
(29 \%)\end{array}$ & $\begin{array}{r}287 \\
(27 \%)\end{array}$ \\
\hline
\end{tabular}

Note: Percentages of total number of keywords per column are in parentheses. Percentages may not sum to $100 \%$ due to rounding.

Public Perception Issues Through the Years

The keywords attached to each article were coded according to nine categories: application field, attitudes and perceptions, factors and determinants, research method, location, subjects, ethical aspects, and medical and other aspects. The 413 articles with keywords attached provided a total 
of 1,793 keywords, which represents an average of 4.3 keywords per article author has chosen to represent the contents of each article.

Table 4 shows the breakdown of keywords across the types of genomics, the three periods, and the categories of author productivity. There seems to be little difference in the mean number of keywords per article. Most keywords refer to the application field of genomics studied in the article (31\%), followed by attitudes and perceptions (12\%), and factors and determinants influencing public perception (12\%). More productive authors used more keywords referring to determinants than other authors, and we see an increasing use of these keywords over the years. Within the group of articles on red genomics, only $4 \%$ of the keywords refer to factors and determinants. However, within the group of articles on red genomics $11 \%$ of the keywords refer to medical aspects, which is relatively more than in articles on other types of genomics. The declining attention paid to ethical aspects of genomics through the years (see Table 3 ) is not clearly reflected in the keywords used to refer to ethical issues. Comparing articles on red and green genomics, we have found fewer keywords that refer to ethical aspects within the latter.

\section{Research Type of the Articles}

Finally, we coded for the type and method of research described. From Table 5, we can see that a large number of abstracts were unclear with respect to the type (30\%) and method (28\%) of research conducted; therefore, they could not be coded. This also resulted in less satisfying coder agreement, and consequently, the following results on methodologies used should be interpreted with care. Assessing for trends over the three time periods, we see abstracts becoming more detailed in this regard as the years progressed. The data in Table 5 indicates that the most frequently used method for research on the public perception of genomics-across all periods, for all authors, and for all genomics types-is survey research (37\%). Still, articles describing research on genomics in general indicate that desk research or narrative essays were also utilized in a substantial portion of the studies (17\%). Focus groups and experiments were used less substantially ( $5 \%$ and $4 \%$, respectively), but both have slightly increased in popularity in recent years. The data regarding the distribution of quantitative and qualitative research indicates that these types of research were more equally conducted in studies on red genomics, whereas within articles on green genomics, the emphasis has clearly been on quantitative research.

\subsection{Discussion and Conclusions}

In this study, we have made an attempt to systematically characterize the scientific literature about the public perception of genomics. We looked for developments in all literature on the topic which was available in the two most important databases for the field: Web of Science and Scopus. We did this by sampling relevant indicators from the published articles, derived from the abstracts and reference information, and analysing them in terms of their time periods, authorship and types of genomics. In total, 451 articles were included in our review.

In this study, we focused solely on the material provided by the online databases Web of Science and Scopus. Based on the large number of peerreviewed journals listed in both databases, we 
Table 5

Breakdown of Research Type and Research Method by Type of Genomics, Period of Publication and Authorship (in Percentages)

\begin{tabular}{|c|c|c|c|c|c|c|c|c|c|c|c|}
\hline \multirow[b]{3}{*}{ Research Type } & \multirow{3}{*}{$\begin{array}{l}\text { Total in } \\
\text { sample }\end{array}$} & \multicolumn{4}{|c|}{ Type of Genomics } & \multicolumn{3}{|c|}{ Period } & \multicolumn{3}{|c|}{ Authorship (Articles) } \\
\hline & & $\begin{array}{r}\text { Un- } \\
\text { specified }\end{array}$ & Green & Red & $\begin{array}{r}\text { Other } \\
\text { and } \\
\text { Combi- } \\
\text { nation }\end{array}$ & $\begin{array}{r}1970- \\
1997\end{array}$ & $\begin{array}{l}1998- \\
2003\end{array}$ & $\begin{array}{r}2004- \\
2006\end{array}$ & $\geq 4$ & $20 r 3$ & 1 \\
\hline & & & & & & & & & & & \\
\hline Quantitative & $\begin{array}{r}186 \\
(41 \%)\end{array}$ & $\begin{array}{r}17 \\
(29 \%)\end{array}$ & $\begin{array}{r}118 \\
(44 \%)\end{array}$ & $\begin{array}{r}43 \\
(40 \%)\end{array}$ & $\begin{array}{r}8 \\
(47 \%)\end{array}$ & $\begin{array}{r}18 \\
(33 \%)\end{array}$ & $\begin{array}{r}73 \\
(34 \%)\end{array}$ & $\begin{array}{r}95 \\
(53 \%)\end{array}$ & $\begin{array}{r}41 \\
(51 \%)\end{array}$ & $\begin{array}{r}52 \\
(48 \%)\end{array}$ & $\begin{array}{r}93 \\
(36 \%)\end{array}$ \\
\hline Qualitative & $\begin{array}{r}105 \\
(23 \%)\end{array}$ & $\begin{array}{r}18 \\
(31 \%)\end{array}$ & $\begin{array}{r}51 \\
(19 \%)\end{array}$ & $\begin{array}{r}30 \\
(28 \%)\end{array}$ & $\begin{array}{r}6 \\
(35 \%)\end{array}$ & $\begin{array}{r}5 \\
(9 \%)\end{array}$ & $\begin{array}{r}56 \\
(26 \%)\end{array}$ & $\begin{array}{r}44 \\
(24 \%)\end{array}$ & $\begin{array}{r}19 \\
(24 \%)\end{array}$ & $\begin{array}{r}22 \\
(20 \%)\end{array}$ & $\begin{array}{r}64 \\
(25 \%)\end{array}$ \\
\hline $\begin{array}{l}\text { Combination } \\
\text { Quantitative } \\
\text { \& Qualitative }\end{array}$ & $\begin{array}{r}24 \\
(5 \%)\end{array}$ & $\begin{array}{r}4 \\
(7 \%)\end{array}$ & $\begin{array}{r}18 \\
(7 \%)\end{array}$ & $\begin{array}{r}1 \\
(1 \%)^{1}\end{array}$ & $\begin{array}{r}1 \\
(6 \%)^{1}\end{array}$ & $\begin{array}{r}2 \\
(4 \%)^{2}\end{array}$ & $\begin{array}{r}12 \\
(6 \%)\end{array}$ & $\begin{array}{r}10 \\
(6 \%)\end{array}$ & $\begin{array}{r}8 \\
(10 \%)\end{array}$ & $\begin{array}{r}5 \\
(5 \%)\end{array}$ & $\begin{array}{r}11 \\
(4 \%)\end{array}$ \\
\hline Unclear & $\begin{array}{r}136 \\
(30 \%)\end{array}$ & $\begin{array}{r}19 \\
(33 \%)\end{array}$ & $\begin{array}{r}82 \\
(31 \%)\end{array}$ & $\begin{array}{r}33 \\
(31 \%)\end{array}$ & $\begin{array}{r}2 \\
(12 \%)\end{array}$ & $\begin{array}{r}30 \\
(55 \%)\end{array}$ & $\begin{array}{r}74 \\
(34 \%)\end{array}$ & $\begin{array}{r}32 \\
(18 \%)\end{array}$ & $\begin{array}{r}12 \\
(15 \%)\end{array}$ & $\begin{array}{r}30 \\
(28 \%)\end{array}$ & $\begin{array}{r}93 \\
(36 \%)\end{array}$ \\
\hline \multicolumn{12}{|l|}{$\begin{array}{l}\text { Research } \\
\text { Method }\end{array}$} \\
\hline $\begin{array}{l}\text { Survey/ } \\
\text { interviews }\end{array}$ & $\begin{array}{r}165 \\
(37 \%)\end{array}$ & $\begin{array}{r}17 \\
(29 \%)\end{array}$ & $\begin{array}{r}99 \\
(37 \%)\end{array}$ & $\begin{array}{r}42 \\
(39 \%)\end{array}$ & $\begin{array}{r}7 \\
(41 \%)\end{array}$ & $\begin{array}{r}18 \\
(33 \%)\end{array}$ & $\begin{array}{r}65 \\
(30 \%)\end{array}$ & $\begin{array}{r}82 \\
(45 \%)\end{array}$ & $\begin{array}{r}30 \\
(38 \%)\end{array}$ & $\begin{array}{r}48 \\
(44 \%)\end{array}$ & $\begin{array}{r}87 \\
(33 \%)\end{array}$ \\
\hline $\begin{array}{l}\text { Desk research } \\
\text { /narrative } \\
\text { essay }\end{array}$ & $\begin{array}{r}36 \\
(8 \%)\end{array}$ & $\begin{array}{r}10 \\
(17 \%)\end{array}$ & $\begin{array}{r}22 \\
(8 \%)\end{array}$ & $\begin{array}{r}3 \\
(3 \%)^{2}\end{array}$ & $\begin{array}{r}1 \\
(6 \%)\end{array}$ & $\begin{array}{r}2 \\
(4 \%)^{2}\end{array}$ & $\begin{array}{r}21 \\
(10 \%)\end{array}$ & $\begin{array}{r}13 \\
(7 \%)\end{array}$ & $\begin{array}{r}8 \\
(10 \%)\end{array}$ & $\begin{array}{r}5 \\
(5 \%)\end{array}$ & $\begin{array}{r}23 \\
(9 \%)\end{array}$ \\
\hline Focus groups & $\begin{array}{r}21 \\
(5 \%)\end{array}$ & $(2 \%)^{1}$ & $\begin{array}{r}6 \\
(2 \%)\end{array}$ & $\begin{array}{r}13 \\
(12 \%)\end{array}$ & $(6 \%)^{1}$ & $\begin{array}{r}0 \\
(0 \%)\end{array}$ & $\begin{array}{r}11 \\
(5 \%)\end{array}$ & $\begin{array}{r}10 \\
(6 \%)\end{array}$ & $\begin{array}{r}6 \\
(8 \%)\end{array}$ & $\begin{array}{r}5 \\
(5 \%)\end{array}$ & $\begin{array}{r}10 \\
(4 \%)\end{array}$ \\
\hline Experiment & $\begin{array}{r}20 \\
(4 \%)\end{array}$ & $\begin{array}{r}0 \\
(0 \%)\end{array}$ & $\begin{array}{r}18 \\
(7 \%)\end{array}$ & $\begin{array}{r}2 \\
(2 \%)\end{array}$ & $\begin{array}{r}0 \\
(0 \%)\end{array}$ & $\begin{array}{r}0 \\
(0 \%)\end{array}$ & $\begin{array}{r}9 \\
(4 \%)\end{array}$ & $\begin{array}{r}11 \\
(6 \%)\end{array}$ & $\begin{array}{r}8 \\
(10 \%)\end{array}$ & $\begin{array}{r}1 \\
(1 \%)^{-}\end{array}$ & $\begin{array}{r}11 \\
(4 \%)\end{array}$ \\
\hline Review & $\begin{array}{r}14 \\
(3 \%)\end{array}$ & $(2 \%)^{1}$ & $\begin{array}{r}9 \\
(3 \%)\end{array}$ & $\begin{array}{r}2 \\
(2 \%)\end{array}$ & $\begin{array}{r}2 \\
(12 \%)^{2}\end{array}$ & $(2 \%)^{1}$ & $\begin{array}{r}5 \\
(2 \%)\end{array}$ & $\begin{array}{r}8 \\
(4 \%)\end{array}$ & $\begin{array}{r}2 \\
(3 \%)^{2}\end{array}$ & $\begin{array}{r}3 \\
(3 \%)^{3}\end{array}$ & $\begin{array}{r}9 \\
(3 \%)\end{array}$ \\
\hline $\begin{array}{l}\text { Content } \\
\text { analysis/ } \\
\text { media }\end{array}$ & $\begin{array}{r}11 \\
(2 \%)\end{array}$ & $\begin{array}{r}4 \\
(7 \%)\end{array}$ & $\begin{array}{r}3 \\
(1 \%)^{2}\end{array}$ & $\begin{array}{r}3 \\
(3 \%)^{3}\end{array}$ & $\begin{array}{r}1 \\
(6 \%)^{1}\end{array}$ & $\begin{array}{r}0 \\
(0 \%)\end{array}$ & $\begin{array}{r}4 \\
(2 \%)\end{array}$ & $\begin{array}{r}7 \\
(4 \%)\end{array}$ & $\begin{array}{r}2 \\
(3 \%)^{2}\end{array}$ & $\begin{array}{r}4 \\
(4 \%)\end{array}$ & $\begin{array}{r}5 \\
(2 \%)\end{array}$ \\
\hline $\begin{array}{l}\text { Mixed } \\
\text { methods }\end{array}$ & $\begin{array}{r}38 \\
(8 \%)\end{array}$ & $\begin{array}{r}6 \\
(10 \%)\end{array}$ & $\begin{array}{r}23 \\
(9 \%)\end{array}$ & $\begin{array}{r}7 \\
(7 \%)\end{array}$ & $\begin{array}{r}2 \\
(12 \%)^{2}\end{array}$ & $\begin{array}{r}2 \\
(4 \%)^{2}\end{array}$ & $\begin{array}{r}19 \\
(9 \%)\end{array}$ & $\begin{array}{r}17 \\
(9 \%)\end{array}$ & $\begin{array}{r}8 \\
(10 \%)\end{array}$ & $\begin{array}{r}11 \\
(10 \%)\end{array}$ & $\begin{array}{r}19 \\
(7 \%)\end{array}$ \\
\hline Other & $\begin{array}{r}20 \\
(4 \%)\end{array}$ & $\begin{array}{r}2 \\
(3 \%)^{2}\end{array}$ & $\begin{array}{r}11 \\
(4 \%)\end{array}$ & $\begin{array}{r}6 \\
(6 \%)\end{array}$ & $(6 \%)^{1}$ & $(6 \%)^{3}$ & $\begin{array}{r}11 \\
(5 \%)\end{array}$ & $\begin{array}{r}6 \\
(3 \%)\end{array}$ & $\begin{array}{r}3 \\
(4 \%)^{2}\end{array}$ & $\begin{array}{r}3 \\
(3 \%)^{2}\end{array}$ & $\begin{array}{r}14 \\
(5 \%)\end{array}$ \\
\hline Unclear & $\begin{array}{r}126 \\
(28 \%)\end{array}$ & $\begin{array}{r}17 \\
(29 \%)\end{array}$ & $\begin{array}{r}78 \\
(29 \%)\end{array}$ & $\begin{array}{r}29 \\
(27 \%)\end{array}$ & $\begin{array}{r}2 \\
(12 \%)\end{array}$ & $\begin{array}{r}29 \\
(53 \%)\end{array}$ & $\begin{array}{r}70 \\
(33 \%)\end{array}$ & $\begin{array}{r}27 \\
(15 \%)\end{array}$ & $\begin{array}{r}13 \\
(16 \%)\end{array}$ & $\begin{array}{r}29 \\
(27 \%)\end{array}$ & $\begin{array}{r}83 \\
(32 \%)\end{array}$ \\
\hline Totalsample & 451 & 58 & 269 & 107 & 17 & 55 & 215 & 181 & 80 & 109 & 261 \\
\hline
\end{tabular}

Note: Percentages may not sum to $100 \%$ due to rounding. 
are convinced that our sample adequately reflects the developments in research on the public perception of genomics from 1970 through 2006 , as was published in peer-reviewed journals. Scopus and Web of Science appeared to complement each other well.

In the study presented, we coded only the abstracts and reference information of the 451 articles. While fully coding all 451 articles would have been virtually impossible, using only the abstracts limits the depth of the study somewhat. Nevertheless, the information culled from these abstracts still forms the primary selection criteria that scholars use in searching for references.

Returning to our research questions, we can characterise the literature on the public perception of genomics (Question 1) as having expanded along with the field's popularity in the decade since the "watershed years." Many incidental authors, as well as a small group of productive authors, focus most of their attention on food and agriculture genomics. This research has shifted in its focus from ethics to perceived benefits and risks. We also find that research on this topic is published in 250 different journals. This raises interesting questions about why there is such breadth of research on this topic and perhaps not as much depth. It is possible that because this is a relatively young research field, it has spawned few dedicated journals so far.

Looking at trends in the literature (Question 2), we see indications of strong autonomic growth in the number of research articles published over the years. Although this may have been caused by a growing number of researchers and journals or by changes in publishing technologies, the strong growth is still clearly recognizable in an absolute sense. We can observe a similar curve (although delayed) with similar phasing in the media coverage of the field (Bauer \& Gutteling, 2006). It seems likely that public pressure has indeed had some effect on the scientific research agenda. Furthermore, we see a relatively clear dividing line between the groups of journals and authors publishing on either red or green genomics. Apparently, the division Bauer (2005) showed between red and green genomics in both the press and public perception has been similarly expressed within the scientific world-with the main focus on green genomics, especially in Western Europe. This can possibly be explained by the great media attention to the public debates over whether or not the introduction of GM food in the EU is desirable. In the US, while GM food is already very common, issues like abortion and cloning are under debate, which may explain the focus on red genomics.

It is remarkable that almost no research chronicled by the articles within our sample originated in thirdworld countries, given that these countries could potentially benefit the most from a new technological development like genomics. However, examining other databases might reveal more studies from developing countries.

What we see in this field is that social science research is linked to public opinion and attitudes. European researchers tend to focus more on topics related to agri/plant genomics, while researchers in the United States focus more on the field's medical applications. The Atlantic divide, the widening gap between the fortunes of genomics in North America and Europe (Gaskell, Einseidel, et al., 2001), is reflected in the ELSA research publications. This study also shows trends in topics and keywords over time. Why are certain issues or types of research more frequent on one continent than on another? A possible explanation could be that the EU funds 
more studies of the agri/plant type and has set specific parameters that have guided research across EU countries. Additionally, the great extent of the public controversy around this topic may have caused a social basis for research. The study also finds that more agri/plant studies than medical studies focus on both risk and benefit perceptions and that there is more attention paid to risks than benefits.

The scientific nature of published papers on public perception (Question 3) was often unclear. The abstracts provided so little information that coding was difficult. This resulted in less satisfying intercoder agreement and, consequently, the results on methodologies used should be interpreted with care. Fortunately, more recently published abstracts reflect an increase in the clarity with which theories and methods used are described; however, only $10 \%$ of the abstracts express a theoretical framework for the studies they present. Furthermore, although $37 \%$ of all articles describe the results of public surveys, only $8 \%$ of the abstracts mention systematic research on the determinants of public perception or on modelling the sociopsychological process of forming the public perception of genomics and its determinants. These results do not necessarily mean that every other study is performed without a theoretical foundation. Still, the quality of abstracts appears problematic in many cases, particularly if the quality of an abstract is considered an indicator of the quality of the research described. If journals were to state conditions or formats for abstracts, this might improve their quality; in other research fields, this is already the norm.

Of the articles in our sample, $30 \%$ do not clearly express the research methods used. This result is markedly different from systematic reviews in other research fields (see, e.g., Gurabardhi et al., 2004). Of the large number of articles that are unclear in this respect, a portion might consist of articles without empirical data. Together with the fact that only $10 \%$ of the abstracts in our database name a theoretical basis for the research they describe, it seems that there is a balance at stake between narratives or reflective research and the development of theories based on data collection. This needs to be examined more closely and deserves particular attention in this specific field.

The range of specific determinants that influence the public perception of genomics (Question 4) studied so far is broad. $39 \%$ of the studies in this review raised the possible influence of determinants like trust, knowledge, beliefs, interest, concern, affect, demographics, worldview, lifestyle, religion, and so forth. However, the hypotheses were not always tested with empirical data; based on the abstract information, only $8 \%$ of our sample was tested with empirical data.

As the results of this study have shown, a division is evident between research on green and red genomics which also corresponds with a division between the EU and the United States. Crossfertilization between perception research on medical genomics and nutrigenomics could bring the research field of the public perception of genomics to a higher level. Furthermore, empirical studies in which models and theories are put to the test will provide a sound foundation for the further development of public perception research in the field of genomics. Exploring the different determinants of public perception in more detail will increase our understanding of the sociopsychological process that affect the public perception of genomics. 
Notes

1. Red genomics refers to medical processes and includes applications such as gene therapy, genetic testing, pharmaceuticals, and medicines. Green genomics refers to agricultural processes such as plant and animal breeding, GMO releases, GM foods, functional foods, and personalised nutrition. Besides red and green, other applications of genomics have become available; this include white (industrial) genomics, which aims at making industrial processes cheaper while causing less damage to the environment for a sustainable future.

2. The following search key was used: (consumer* or public) AND (attitude* or opinion or perception or acceptance or communication) AND (genomics or "genetically modified" or gm or "genetic modification" or "genetic engineering" or genetics). The search key was the result of preparatory study. Some obvious terms, e.g. gene technology and biotechnology, were excluded, as they did not contribute additional relevant articles. A list of all 451 articles is available upon request to the authors by e-mail.

3. The agreement among the coders was less satisfying on two of the eight variables. Besides the ambiguity of the performed research discussed in a large portion of the abstracts, the intercoder disagreement was partly due to the second coder's insufficient training on recognizing research methods. The inconsistencies in coding were discussed, after which a final code was determined. 


\section{References}

Bauer, M. W. (2005). Distinguishing red and green biotechnology: Cultivation effects of the elite press. International Journal of Public Opinion Research, 17(1), 63-89.

Bauer, M. W., \& Gutteling, J. (2006). Issues Salience and Media Framing over 30 Years. In G. Gaskell \& M. W. Bauer (Eds.), Genomics and society: legal, ethical, and social dimensions (pp. 113-130). London: Earthscan.

Bredahl, L. (1999). Consumers' cognitions with regard to genetically modified foods. Results of a qualitative study in four countries. Appetite, 33(3), 343-360.

Collins, F. S., Morgan, M., \& Patrinos, A. (2003). The human genome project: Lessons from large-scale biology. Science, 300(5617), 286-290.

Condit, C. (2001). What is "public opinion" about genetics? Nature Reviews Genetics, $2(10), 811-815$.

Finucane, M. L., \& Holup, J. L. (2005). Psychosocial and cultural factors affecting the perceived risk of genetically modified food: an overview of the literature. Social Science \& Medicine, 60(7), 1603-1612.

Frewer, L. J., Howard, C., \& Shepherd, R. (1997). Public concerns in the United Kingdom about general and specific applications of genetic engineering: Risk, benefit, and ethics. Science Technology \& Human Values, 22(1), 98-124.

Gaskell, G., Allum, N., Bauer, M., Durant, J., Allansdottir, A., Bonfadelli, H., et al. (2000). Biotechnology and the European public. Nature Biotechnology, 18(9), 935-938.

Gaskell, G., Bauer, M. W., Durant, J., \& Allum, N. C. (1999). Worlds apart? The reception of genetically modified foods in Europe and the US. Science, 285(5426), 384-387.

Gaskell, G., Allum, N., Wagner, W., Kronberger, N., Torgersen, H., Hampel, J., et al. (2004). GM foods and the misperception of risk perception. Risk Analysis, 24(1), 185-194.

Gaskell, G., Allum, N., Wagner, W., Nielsen, T. H., Jelsoe, E., Kohring, M., et al. (2001). In the public eye: Representations of biotechnology in Europe. In G. Gaskell \& M. Bauer 26 Science Communication (Eds.), Biotechnology 1996-2000: The years of controversy (pp. 53-79). London: NMSI Trading Ltd, Science Museum.

Gaskell, G., \& Bauer, M. (2001). Biotechnology in the years of controversy: a social scientific perspective. In G. Gaskell \& M. Bauer (Eds.), Biotechnology 1996-2000: The Years of Controversy (pp.3-11). London: NMSI Trading Ltd, Science Museum.

Gaskell, G., Einsiedel, E., Priest, S., Ten Eyck, T., Allum, N., \& Torgerson, H., (2001). Troubled waters: the Atlantic divide on biotechnology policy. In G. Gaskell \& M. Bauer (Eds.), Biotechnology 1996-2000: Theyears of controversy (pp.96-115). London: NMSI Trading Ltd, Science Museum.

Grunert, K. G. (2002). Current issues in the understanding of consumer food choice. Trends in Food Science \& Technology, 13(8), 275-285. 
Gurabardhi, Z., Gutteling, J. M., \& Kuttschreuter, M. (2004). The development of risk communication. Science Communication, 25(4), 323-349.

Lusk, J. L., Jamal, M., Kurlander, L., Roucan, M., \& Taulman, L. (2005). A meta-analysis of genetically modified food valuation studies. Journal of Agricultural and Resource Economics, $30(1), 28-44$.

McComas, K. A. (2006). Defining moments in risk communication research: 19962005. Journal Of Health Communication, 11(1), 75-91.

Miles, S., \& Frewer, L. J. (2001). Investigating specific concerns about different food hazards. Food Quality and Preference, 12(1), 47-61.

Ronteltap,A.,van Trijp, J.C.M., Renes, R.J., \&Frewer, L.J. (2007). Consumeracceptance of technology-based food innovations: Lessons for the future of nutrigenomics. Appetite, 49(1), $1-17$.

Sjöberg, L. (2001). Limits of knowledge and the limited importance of trust. Risk Analysis, 21(1), 189-198.

Verdurme, A., \& Viaene, J. (2001). Consumer attitudes towards GM food: Literature review and recommendations for effective communication. Journal of International Food and Agribusiness Marketing, 13(2-3), 77-98.

Wynne, B. (2001). Creating public alienation: expert cultures of risk and ethics on GMOs. Sci Cult (Lond), 10(4), 445-481.

Zwier, S., Beentjes, H., \& Gutteling, J. (2006). Communicatiewetenschappelijk onderzoek in de afgelopen 15jaar: aard en positie. Tijdschrift voor Communicatiewetenschap, 34(3), 220-231. 


\section{Appendices}

\begin{tabular}{|c|c|c|c|}
\hline Variable & Number of Categories & $\begin{array}{c}\text { Agreement } \\
\text { (\% of } 70 \text { studies) }\end{array}$ & Cohen's Kappa \\
\hline Type of Genomics & 4 & $81 \%$ & .675 \\
\hline Attitude & 2 & $74 \%$ & .472 \\
\hline Benefit Perception & 2 & $84 \%$ & .574 \\
\hline Risk Perception & 2 & $74 \%$ & .442 \\
\hline EthicalAspects & 2 & $89 \%$ & .702 \\
\hline Other determinants & 2 & $71 \%$ & .413 \\
\hline Research Type & 4 & $60 \%$ & .405 \\
\hline Research Method & 9 & $60 \%$ & .478 \\
\hline
\end{tabular}


Appendix 2

Thirteen Most Cited Articles (more than twenty-five citations) and Their Citation

\begin{tabular}{|c|c|c|c|c|c|c|c|}
\hline Authors & Country & Journal Title & $\begin{array}{l}\text { Publication } \\
\text { Year }\end{array}$ & $\begin{array}{l}\text { Citations } \\
(n)\end{array}$ & $\begin{array}{l}\text { Articles by } \\
\text { Author in } \\
\text { study }(n)\end{array}$ & $\begin{array}{l}\text { Type of } \\
\text { Genomics }\end{array}$ & $\begin{array}{l}\text { Author/Publishers } \\
\text { Keywords }\end{array}$ \\
\hline Clayton et al. & US & $\begin{array}{l}\text { J. of the } \\
\text { American } \\
\text { Medical } \\
\text { Association }\end{array}$ & 1995 & $\begin{array}{l}127 \\
(S)\end{array}$ & 1 & Red & $\begin{array}{l}\text { informed consent; } \\
\text { medical research;DNA } \\
\text { Data Banks; Genetic } \\
\text { Information; Genetic } \\
\text { Research Databases; } \\
\text { Nucleic Acid; Disclosure; } \\
\text { Ethics, Medical; Genetic } \\
\text { Privacy; Genetics, } \\
\text { Medical; Informed } \\
\text { Consent; Research }\end{array}$ \\
\hline Gaskell et al. & UK & Science & 1999 & $\begin{array}{r}89 \\
\text { (WoS) }\end{array}$ & 6 & Green & - \\
\hline $\begin{array}{l}\text { Croyle \& } \\
\text { Lerman }\end{array}$ & US & $\begin{array}{l}\text { Preventive } \\
\text { Medicine }\end{array}$ & 1993 & $\begin{array}{l}77 \\
(S)\end{array}$ & 1 & Red & $\begin{array}{l}\text { cancer susceptibility; } \\
\text { colon cancer; Attitude to } \\
\text { Health }\end{array}$ \\
\hline Gaskell et al. & UK & $\begin{array}{l}\text { Nature } \\
\text { biotechnology }\end{array}$ & 2000 & $\begin{array}{l}68 \\
(S)\end{array}$ & 6 & Combi & $\begin{array}{l}\text { Biotechnology; Public } \\
\text { Opinion }\end{array}$ \\
\hline Frewer et al. & UK & $\begin{array}{l}\text { Science } \\
\text { Technology \& } \\
\text { Human Values }\end{array}$ & 1997 & $\begin{array}{r}53 \\
(\text { WoS })\end{array}$ & 18 & Combi & Perception; food \\
\hline Kerr et al. & UK & $\begin{array}{l}\text { Public } \\
\text { Understanding } \\
\text { of Science }\end{array}$ & 1998 & $\begin{array}{l}46 \\
(S)\end{array}$ & 1 & $\begin{array}{l}\text { Un- } \\
\text { specified }\end{array}$ & $\begin{array}{l}\text { public participation; } \\
\text { attitude; consumer; } \\
\text { genetic research; genetic } \\
\text { screening; genetics; } \\
\text { prenatal diagnosis; } \\
\text { public opinion; Genetic } \\
\text { Research; Public } \\
\text { Participation; Consumer } \\
\text { Participation; Genetic } \\
\text { Screening; Genetics; } \\
\text { Knowledge, Attitudes, } \\
\text { Practice; Prenatal } \\
\text { Diagnosis; Public Opinion }\end{array}$ \\
\hline Howell et al. & US & $\begin{array}{l}\text { Archives } \\
\text { of Internal } \\
\text { Medicine }\end{array}$ & 1999 & $\begin{array}{r}42 \\
(\text { WoS })\end{array}$ & 1 & Red & $\begin{array}{l}\text { Primary-care; follow-up; } \\
\text { population; mutations; } \\
\text { relatives; disease; } \\
\text { acceptance; education; } \\
\text { carriers; program }\end{array}$ \\
\hline $\begin{array}{l}\text { Richards \& } \\
\text { Ponder }\end{array}$ & UK & $\begin{array}{l}\text { Journal of } \\
\text { Medical } \\
\text { Genetics }\end{array}$ & 1996 & $\begin{array}{l}34 \\
(\mathrm{~S})\end{array}$ & 1 & Red & $\begin{array}{l}\text { Genetic counselling; } \\
\text { Genetic education; } \\
\text { Kinship; genetics; } \\
\text { Genetics; Knowledge, } \\
\text { Attitudes, Practice }\end{array}$ \\
\hline Wynne & UK & $\begin{array}{l}\text { Science as } \\
\text { Culture }\end{array}$ & 2001 & $\begin{array}{l}33 \\
(\mathrm{~S})\end{array}$ & 2 & Green & $\begin{array}{l}\text { public opinion; risk } \\
\text { assessment; transgenic } \\
\text { plant; Plants, Genetically } \\
\text { Modified; Public Opinion; } \\
\text { RiskAssessment }\end{array}$ \\
\hline
\end{tabular}




\begin{tabular}{|c|c|c|c|c|c|c|c|}
\hline Authors & Country & Journal Title & $\begin{array}{l}\text { Publication } \\
\text { Year }\end{array}$ & $\begin{array}{l}\text { Citations } \\
\text { (n) }\end{array}$ & $\begin{array}{l}\text { Articles bij } \\
\text { Author in } \\
\text { study (n) }\end{array}$ & $\begin{array}{l}\text { Type of } \\
\text { Genomics }\end{array}$ & $\begin{array}{l}\text { Author/Publishers } \\
\text { Keywords }\end{array}$ \\
\hline Petersen & Australia & $\begin{array}{l}\text { Social Science } \\
\text { and Medicine }\end{array}$ & 2001 & $\begin{array}{r}32 \\
(\mathrm{~S})\end{array}$ & 1 & Red & $\begin{array}{l}\text { Australia; Genetics; } \\
\text { Medicine; News media; } \\
\text { genetics; medicine; } \\
\text { Publication; Genetics; } \\
\text { Mass Media; Newspapers; } \\
\text { Public Opinion; Public } \\
\text { Relations }\end{array}$ \\
\hline $\begin{array}{l}\text { Miles \& } \\
\text { Frewer }\end{array}$ & UK & $\begin{array}{l}\text { Food Quality } \\
\text { and Preference }\end{array}$ & 2001 & $\begin{array}{r}29 \\
\text { (WoS) }\end{array}$ & 5 & Green & $\begin{array}{l}\text { risk perception; food } \\
\text { hazards; laddering } \\
\text { technique; public } \\
\text { perceptions; decision- } \\
\text { making; perceived risk; } \\
\text { safety; participation; } \\
\text { benefit; trust }\end{array}$ \\
\hline Sjöberg & Sweden & Risk Analysis & 2001 & $\begin{array}{r}28 \\
(S)\end{array}$ & 2 & Green & $\begin{array}{l}\text { Demand for risk } \\
\text { mitigation; Experts } \\
\text { politicians; Risk } \\
\text { perception; Trust; Data } \\
\text { reduction; Nuclear } \\
\text { energy; Radioactive } \\
\text { wastes; Regression } \\
\text { analysis; Risk perception; } \\
\text { Technology; Genetically } \\
\text { modified food; Public } \\
\text { policy; attitudinalsurvey; } \\
\text { knowledge; public } \\
\text { attitude; sociology }\end{array}$ \\
\hline Bredahl & Denmark & Appetite & 1999 & $\begin{array}{r}27 \\
(\text { WoS })\end{array}$ & 4 & Green & - \\
\hline
\end{tabular}

Note: Publisher keywords are listed in italics when author keywords are not provided.

$\mathrm{S}=$ Citation Index of Scopus; WoS = Citation Index of Web of Science 
Appendix 3

Ten Most Relevant Journals for Public Perception of Genomics Research

(with 7 or more publications between 1970 and 2006)

\begin{tabular}{|c|c|c|c|c|c|c|c|c|c|c|c|}
\hline \multirow[b]{2}{*}{ Journal (ISSN) } & \multirow[b]{2}{*}{$\begin{array}{r}\text { Articles } \\
\text { in } \\
\text { sample } \\
(n) \\
\end{array}$} & \multicolumn{4}{|c|}{ Type of genomics } & \multicolumn{3}{|c|}{ Period } & \multicolumn{3}{|c|}{ Authorship (Articles) } \\
\hline & & $\begin{array}{r}\text { Un- } \\
\text { specified }\end{array}$ & Green & Red & $\begin{array}{r}\text { Other } \\
\text { and } \\
\text { Combi- } \\
\text { nation }\end{array}$ & $\begin{array}{r}1970- \\
1997\end{array}$ & $\begin{array}{l}1998- \\
2003\end{array}$ & $\begin{array}{r}2004- \\
2006\end{array}$ & $\geq 4$ & $20{ }^{2} 3$ & 1 \\
\hline $\begin{array}{l}\text { AgBioForum } \\
(1522936 X)\end{array}$ & 23 & 1 & 19 & $\circ$ & 3 & $\circ$ & 9 & 14 & 6 & 6 & 11 \\
\hline $\begin{array}{l}\text { Risk Analysis } \\
(0272-4332)\end{array}$ & 17 & 2 & 15 & $\circ$ & ० & ० & 6 & 11 & 10 & 1 & 6 \\
\hline $\begin{array}{l}\text { Public } \\
\text { Understanding of } \\
\text { Science } \\
(0963-6625)\end{array}$ & 15 & 5 & 8 & 1 & 1 & $\circ$ & 6 & 9 & 3 & 4 & 8 \\
\hline $\begin{array}{l}\text { Food Quality and } \\
\text { Preference } \\
\text { (0950-3293) }\end{array}$ & 10 & ० & 10 & $\circ$ & ० & 2 & 3 & 5 & 5 & 4 & 1 \\
\hline $\begin{array}{l}\text { International } \\
\text { Journal of } \\
\text { Biotechnology } \\
(0963-6048)\end{array}$ & 10 & 2 & 8 & $\circ$ & ० & ० & 7 & 3 & 3 & 3 & 4 \\
\hline $\begin{array}{l}\text { Appetite } \\
\text { (0195-6663) }\end{array}$ & 9 & ० & 9 & ० & $\circ$ & 1 & 3 & 5 & 2 & 1 & 6 \\
\hline $\begin{array}{l}\text { Journal of Risk } \\
\text { Research } \\
(1366-9877)\end{array}$ & 8 & 3 & 4 & ० & 1 & ० & 2 & 6 & 3 & 2 & 3 \\
\hline $\begin{array}{l}\text { New Genetics and } \\
\text { Society } \\
(1463-6778)\end{array}$ & 8 & 4 & 2 & 2 & ० & ० & 6 & 2 & 2 & 2 & 4 \\
\hline $\begin{array}{l}\text { Nature } \\
\text { biotechnology } \\
(1087-0156)\end{array}$ & 7 & 1 & 4 & 1 & 1 & 1 & 6 & o & 1 & 4 & 2 \\
\hline $\begin{array}{l}\text { Community } \\
\text { Genetics } \\
(1422-2795) \\
\end{array}$ & 7 & o & o & 7 & ० & ० & 4 & 3 & 1 & o & 6 \\
\hline $\begin{array}{l}\text { Total } \\
\text { (10 journals) }\end{array}$ & $\overline{114}$ & 18 & 79 & 11 & 6 & 4 & 52 & 58 & 36 & 27 & 51 \\
\hline Total sample & 451 & 58 & 269 & 107 & 17 & 55 & 215 & 181 & 80 & 109 & 261 \\
\hline $\begin{array}{l}\text { Percentage of total } \\
\text { articles found in } \\
10 \text { most relevant } \\
\text { journals }\end{array}$ & $25 \%$ & $31 \%$ & $29 \%$ & $10 \%$ & $35 \%$ & $7 \%$ & $24 \%$ & $32 \%$ & $45 \%$ & $25 \%$ & $20 \%$ \\
\hline
\end{tabular}




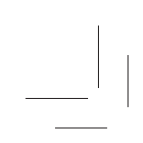

1 


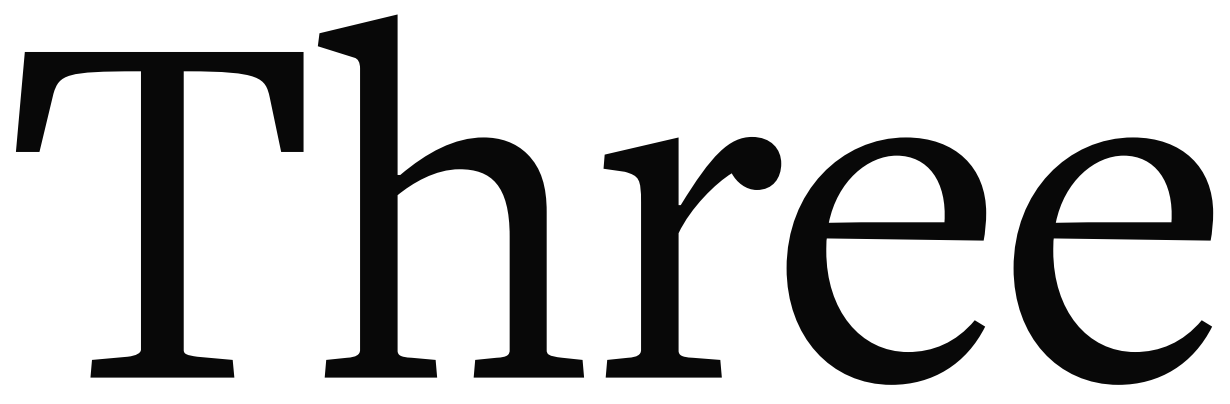

Determinants of Reactions

to Gene-technology -

A Generic Approach

Renske R. Pin

Jan M. Gutteling

Margôt Kuttschreuter

New Genetics and Society 2009: 28(1): 51-65.

DOI: $10.1080 / 14636770802670258$ 


\section{Abstract}

This paper examines the reactions to gene technology (the intention to buy gene-tech food, worry about abuse, and the public's desire that different actors be able to influence decisions) in a sample of the Dutch population $(n=1010)$ and studies the relationship between these reactions and perception, trust, experience, knowledge and personal interest. The survey reveals that large parts of the public are concerned about the abuse of gene technology, are not willing to buy genetech products, and want actors to have an influence on legislation and enforcement. Path analysis shows that these reactions can be well-explained using a generic model. Trust in authorities, personal interest in gene technology, and perception of gene technology are important predictors of people's reactions, whereas experience and knowledge are less important.

Keywords:

perception, trust, gene technology, cognitive and affective factors. 


\section{Three}

\author{
Determinants of Reactions to Gene-technology -
}

\author{
A Generic Approach
}

\subsection{Introduction}

Gene technology is currently the subject of both scientific and public debate. While technological development continues and the technology's potential grows, public support has not followed suit. When science approaches value-laden issues like therapeutic cloning or stem cell research, the public is increasingly claiming a voice in regulation (Leshner, 2005). Perceived risks for health and the environment, the perception that producers benefit more than consumers, and ethical questions have led the public to hesitate about accepting gene technology in medical applications and especially in food and agricultural applications (Gaskell et al., 2006; Gaskell et al., 2004). With applications like gene-tech food, storing DNA-information in databases, or mapping DNA in the search for cures for inherited diseases, gene technology applications have reached the transaction level (Horst, Kuttschreuter \& Gutteling, 2007). This means that consumers actually encounter gene technology products and services, and are not exclusively dependent on media information in order to form an opinion (Bauer \& Gutteling, 2006; Gutteling, 2005).

Individuals play different roles-as consumers, citizens, or patients—and this means that at the transaction level, the processes by which individuals reach decisions about an application's risks, benefits, and the associated ethical considerations are more complex than those at the previous, information level. This also means that the consequences these decision processes have on the individual's behaviour may become clearer.

An extensive review of the peer-reviewed literature on public reactions toward gene technology (Pin \& Gutteling, 2006) showed that only a few studies have addressed transaction-level issues regarding gene technology (e.g., Townsend \& Campbell, 2004). Many studies were characterised by single-issue designs, in which public reactions were analysed or modelled for one particular application of gene technology, such as gene-tech food (e.g., Moon \& Balasubramanian, 2004; Mucci, Hough \&Ziliani, 2004) and prenatal genetic testing and prenatalgenetic engineering (e.g., Urban, 1996), and others focussed on one particular dependent variable, such as the acceptance of gene technology (e.g., Tanaka, 2004). This research strategy assumes that each application or dependent variable is associated with a separate psychological decision process. The question that we want to address in this paper is whether this is a valid assumption.

Using data from a representative sample of the Dutch public, we analysed the determinants of the psychological decision process for various applications of gene technology at the transaction level. Path analysis produced a first attempt to deliver a generic perspective on public reactions toward gene technology applications. Our literature review did not reveal any study that has 
attempted this before, although studies focussing on particular domains of this topic have used statistical modelling techniques (e.g., Grunert, Bredahl \& Scholderer, 2003; Siegrist, 1999; Tanaka, 2004).

\subsection{Theoretical framework}

This study focuses on three different reactions, namely the intention to buy gene-tech food, the concern about the abuse of gene technology, and the public's desire that different (societal) actors be able to influence gene technology development. The three reactions are easily-measurable and can be used to operationalise the hopes and concerns of the public. These different reactions reflect the transaction level of gene technology development. Unlike earlier phases, when the public had only indirect experiences to rely on, now the public can respond to a combination of direct experiences with the technology and indirect experiences are based on media information, narratives, and so on.

\subsubsection{Determinants of reactions to gene technology}

These three reactions have a broad range of socio-psychological determinants. Since the early 1980s, various models have been developed to explain and predict the public perception of technological developments (Dowling \& Staelin, 1994). Positive or negative perception has proven to be an important determinant of reactions to new technologies. If we perceive a benefit from a behaviour or choice, the risk associated with it seems smaller. If there is no perceived benefit, the risk seems larger (Frewer, 2004).

Studies have also provided an understanding of cognitive determinants of the perception of technology development, like personal interest (Pardo, Midden, \& Miller, 2002) and knowledge (Shaw, 2002). The extent to which an individual is interested in and informed about gene technology developments has been shown to be a predictor of the perceptions of gene technology applications (Pardo et al., 2002). Personal interest has a significant effect on knowledge, with interest having a positive effect; people with more interest acquire more knowledge. In the case of GM foods, it is clear that higher levels of knowledge coincide with higher levels of acceptance (Moerbeek \& Casimir, 2005). On the other hand, knowledge may be just one of the many factors that influence the opinions concerning GM foods (Cuite, Aquino, \& Hallman, 2005). Others have found that knowledge increases critical opinions about biotechnology (Bauer \& Gutteling, 2006)

Research on other new technologies has shown that experience with the technology (that is, having contact with the technology at the transaction level) can influence knowledge and interest (Grunert et al., 2003). In the EU, direct experience with gene technology in everyday life, such as gene-tech food or medical applications, was still rather rare several years ago (Henneman, Timmermans, \& van der Wal, 2004), but this is changing rapidly. 
Recent risk literature distinguishes between cognitive and affective components of perception (Slovic, Finucane, Peters \& MacGregor, 2004). The literature review by Pin \& Gutteling (2006) identified both cognitive and affective determinants of the perception of gene technology and its consequences. The 'cognitive system' uses algorithms and normative rules, with knowledge being one of its most important motives. This system is relatively slow, requiring effort and conscious control. Relying on images and associations linked by experience to emotion and affect (a feeling that something is good or bad), the 'affective system' is intuitive, fast, mostly automatic, and does not depend on conscious awareness. These two systems operate in parallel, seeming to depend on each other for guidance (Slovic et al., 2004).

Various concepts that can be attributed to the systems can be found in the literature. Trust is a multidimensional concept that has frequently been identified as an affective determinant ${ }^{1)}$ for perception and reactions to gene technology (Frewer, Scholderer, \& Bredahl, 2003; Tanaka, 2004). 'Social trust' refers to people's willingness to rely on experts and institutions when managing risks and technologies as a generalised attitude over particular issues and institutions. Trust in regulators, science, and industry is particularly important when the public perceives itself as having no control over a particular event or activity, having to leave the responsibility for ensuring consumer protection or public welfare to others - as is arguably the case with genetically modified foods (Frewer, 2004). Increased trust in regulators in the gene technology field decreases perceived risk and increases perceived benefit (Frewer, 2004; Siegrist, 2000). Higher levels of trust produce a more positive attitude toward gene-food and make it more likely that people will accept it (Gutteling, Hanssen, van der Veer, \& Seydel, 2006).

Frewer, Howard, Hedderley, and Shepherd (1996) found that information sources are associated with different characteristics that influence the extent to which they are trusted by the public. Expertise by itself does not lead to trust but must be accompanied by other characteristics, such as accountability. Sources with a moderate degree of accountability tend to be trusted more than those with complete freedom (Finucane \& Holup, 2005). Siegrist (2000) demonstrated that trust in the companies and scientists conducting research on gene technologies has a strong effect on the risks and benefits perceived to be associated with those technologies. It follows that the more an individual trusts that the biotechnologyindustryand scientists studyinggene technologyhave the interests of the general population and environment at heart, the less risk and more benefit the individual will perceive to be associated with their scientific endeavours. Other factors, such as ethical and moral considerations or uncertainties and concerns about possible unintended effects, are also determinants of consumer acceptance or rejection of emerging technologies and their products. An important issue, therefore, is exactly how to include societal values when making decisions about regulation and innovation (Frewer, 2004).

\subsubsection{Ageneric model describing the reactions to gene technology}

Contrary to most models (e.g. Moon \& Balasubramanian, 2004; Mucci, et al., 2004; Urban, 1996), in this study we developed and tested a generic model describing the relationships between the variables identified in the literature review (Pin \& Gutteling, 2006) (see Figure 1). This model is not specific to any particular application of gene technology. In the diagram, the perception of 
gene technology was given a central position, and arrows indicate potential causal relationships. Experience with gene technology, personal interest in gene technology, and trust in actors were considered to be determinants of the perception of gene technology, whereas the intention to buy gene-tech products, concern about the abuse of gene technology and desired influential actors were considered to be dependent on this perception.

The literature review identified determinants of the perception of gene technology and its consequences, reflecting cognitive processes, affective processes, and the interaction between the two (Slovic et al., 2004). In the model, experience with gene technology is hypothesised to determine personal interest in and knowledge about the field. Personal interest in gene technology is in turn hypothesised to determine the perception of gene technology. Trust in actors is also considered to be an important determinant of the perception of gene technology.

The central position given to the perception of gene technology does not rule out the possibility that the determinants can also directly influence the consequences; this explains the arrows from interest and trust to the intention to buy gene-tech products, concern about the abuse of gene technology, and desired influential actors. Experience with gene technology and trust in actors were assumed to be unrelated.

\section{$3 \cdot 3$ Method}

\subsubsection{Respondents}

In November 2005, we conducted telephone interviews with a randomly drawn sample of 3119 Dutch individuals, aged 18 and older. Of these, 1010 respondents participated in the research (33\% response rate). Those who declined to participate mainly gave as reasons 'don't feel like it', 'no time', or 'don't see the use of it' and 15\% indicated that the subject didn't appeal to them.

Of the 1010 respondents, $39.5 \%$ were male and $60.5 \%$ female. Age varied between 18 and 90 , with a mean of 49 years of age. $37.9 \%$ of the respondents had a high level of education, while $36.2 \%$ reported a medium level of education and $25.9 \%$ reported a low education level. Household composition, socio-economic position, religious affiliation and the residence of the respondents resembled the Dutch adult population: $78.7 \%$ had children, $57.8 \%$ had paid employment, and $23.8 \%$ said they visited church, mosque, or temple regularly (Statistics Netherlands [CBS], 2006).

\subsubsection{Questionnaire}

This study was based on an earlier survey conducted in 2002, which aimed to reveal trends in the public reaction to applications of gene technology ${ }^{2}$. In designing our questionnaire, we built upon this existing measurement instrument (Pin \& Gutteling, 2005). 


\subsubsection{Dependent Variables: Reactions to Gene Technology}

Three differentreactions togene technologywere measured as dependant variables. The intention to buygene-tech products (e.g. Mucci et al., 2004) was assessed with two items: 'Would you buy fruit or vegetables that are genetically modified?' and 'Would you buy food that contains a geneticallymodified ingredient, for example margarine with genetically-changed soy-protein?' The items were measured on a 5-point scale (definitely not - definitely yes). The correlation between the two items was.79.

The intention to buy or not buy a gene-tech product is one way for the public to indicate their reactions toward this technology. In line with the theory of emotion (Bandura, 1989; Lazarus, 1993), we assume that concern about the technology is another way of expressing these reactions. Therefore, concern about the abuse of gene technology was measured with 3 statements relating to the abuse of DNA material by three different actors: assurance companies, employers, and judicial authorities. The items were measured on a 5 -point scale (not at all concerned - very concerned). The three items had a Cronbach's alpha of .78.

In addition to direct expressions, the public may also express their reaction toward gene technology by supporting societal organisations (NGOs, consumer organisations, or patient organisations) in monitoring gene technology developments and influencing decisions relating to them. In previous studies, we found that large segments of the public trust these organisations (Gutteling et al., 2006). So, the public's desire that different actors be able to influence gene technology development was measured by asking which of twelve actors (see Table 1) should be able to influence the boundaries of research on genes and heredity (2-point scale: yes - no).

\subsubsection{Determinants}

The perception of gene technology was measured with a series of statements relating to 11 developments in the gene technology field, and participants were asked how they evaluated them (see Table 2). The items were measured on a 5-point scale (very positive - very negative). The items had a Cronbach's alpha of .80 .

To measure the trust in actors, respondents were confronted with 6 actors relevant to decisionmaking in gene technology. They were asked who they would trust to give honest information about gene technology. All items were measured on a 5-point scale (little trust - lots of trust). We also asked about the compliance with legislation on gene-research and supervision by the government. These eight items had a Cronbach's alpha of .71 (see Table 2).

Knowledgeaboutgenetechnology was assessed with four items (answers either correct or incorrect) derived from a study by Gaskell et al. (2006). For each respondent, the number of correct answers was counted and divided by four, resulting in a single knowledge score per respondent (min $\circ$, max 1). The four knowledge items are listed in Table 2.

Personal interest in gene technology was measured with 6 statements relating to interest in 
developments in gene technology. These items were measured on a 4-point scale (not interested at all - very interested). The six items had a Cronbach's alpha of .68.

Experience with gene technology was assessed with two questions: 'Have you been offered a genetic test at the moment, or do you know someone who has?' and 'Have you, or someone you know, ever been offered genetic testing?' For each respondent, the number of yes' answers was counted, resulting in a single experience score per respondent ( $\min 0, \max 2)$.

Finally, to assess their demographic background, we asked respondents their gender, age, and educational level. Furthermore, we asked whether they had children and whether they were actively religious, as we expected reactions towards gene technology may be influenced by religious background or, for example in the case of prenatal screening and human cloning, having children.

\section{$3 \cdot 4$ Results}

\subsubsection{Reactions to Gene Technology}

An overview of the results for the dependent variables is shown in Table 1. A small majority of the respondents did not intend to buy gene-tech products $(M=2.25, s d=1.22)$. The respondents also had some concern about the abuse of gene technology $(M=3.18, s d=1.07)$. When asked if actors should be able to influence decisions about research on genes and heredity, many respondents responded slightly above the mean $(M=.57, s d=.22)$.

When we looked at the correlations among these three dependent variables and the demographic variables, we noticed that men, younger people, and people with higher levels of education are more inclined to buy GM foods than women, older people, and people with lower levels of education. People with higher levels of education are more concerned about the possible abuses than people with lower levels of education. Men and younger people are less inclined to grant influence to other actors to make decisions about gene technology, whereas people with higher levels of education and those with children are more inclined to do so (all $r<.25$ ).

\subsubsection{The Determinants of Reactions to Gene Technology}

The perception of gene technology $(M=3.08, s d=.64)$ is multifaceted. Some gene technology applications are seen as negative by the majority of respondents, while others are seen as positive. Together they represent a balanced view of gene technology. Table 2 indicates that the level of knowledge about gene technology $(M=.65, s d=.25)$ and trust in actors $(M=3.16, s d=.60)$ was slightly above the mean of the scale. The level of personal interest in gene technology was slightly below the mean of the scale $(M=2.72, s d=.51)$. Experience with gene technology was rather low $(M=.14, s d=$ $.30)$. 
Table 1.

Results for the dependent variables $(\mathrm{n}=1010)$, and correlations with demographic variables

\begin{tabular}{|c|c|c|c|c|c|c|}
\hline \multirow[t]{2}{*}{ Construct } & \multirow{2}{*}{$\begin{array}{l}\text { Description and Items of } \\
\text { Scale }\end{array}$} & \multicolumn{5}{|c|}{ Correlation with Demographic Variables ${ }^{a}$} \\
\hline & & $\begin{array}{l}\text { Gender } \\
\text { (male) }\end{array}$ & Age & Education & $\begin{array}{l}\text { Having } \\
\text { Children } \\
\end{array}$ & $\begin{array}{l}\text { Being } \\
\text { Religious } \\
\end{array}$ \\
\hline $\begin{array}{l}\text { Intention to buygene-tech } \\
\text { products }\end{array}$ & $\begin{array}{l}5 \text {-point scale }(1-5) ; \\
\alpha=.89 ; M=2.25 ; s d=1.22\end{array}$ & $++^{* * *}$ & $-*$ & $t^{* * * *}$ & & \\
\hline \multicolumn{7}{|l|}{ Buy GM fruit or vegetables? } \\
\hline \multicolumn{7}{|l|}{ Buy food with GM ingredients? } \\
\hline $\begin{array}{l}\text { Concern about abuse of gene } \\
\text { technology }\end{array}$ & $\begin{array}{l}\text { 5-point scale }(1-5) ; \\
\alpha=.78 ; M=3.18 ; s d=1.07\end{array}$ & & & $+* *$ & & \\
\hline \multicolumn{7}{|l|}{ Insurance companies } \\
\hline \multicolumn{7}{|l|}{ Employers } \\
\hline \multicolumn{7}{|l|}{ Justice } \\
\hline Desired influence of actors & $\begin{array}{l}\text { 2-point scale (yes - no); } \\
\mathrm{M}=.57 ; s d=.22\end{array}$ & $-* *$ & $-*$ & $+* *$ & $+* * *$ & \\
\hline \multicolumn{7}{|l|}{ Doctors/dieticians } \\
\hline \multicolumn{7}{|l|}{ Scientists } \\
\hline \multicolumn{7}{|l|}{ Universities } \\
\hline \multicolumn{7}{|l|}{ Ethical committees } \\
\hline \multicolumn{7}{|l|}{ Patients associations } \\
\hline \multicolumn{7}{|l|}{ Me, as a citizen } \\
\hline \multicolumn{7}{|l|}{ Environmental organisations } \\
\hline \multicolumn{7}{|l|}{ Consumer organisations } \\
\hline \multicolumn{7}{|l|}{ Governmental organisations } \\
\hline \multicolumn{7}{|l|}{ Politics } \\
\hline \multicolumn{7}{|l|}{ Pharmaceutical industry } \\
\hline Food industry & & & & & & \\
\hline
\end{tabular}

${ }^{*} \mathrm{p}<.05 .{ }^{* *} \mathrm{p}<.01 .{ }^{* * *} \mathrm{p}<.001$. (all 2-tailed significant levels). $\mathrm{M}=$ mean item score.

aGender: $\mathrm{O}=$ female; $1=$ male. Age: 17-19; 20-39; 40-64; 65-79; 80+. Education: $1=$ low level; $2=$ medium level; $3=$ high level. Having children: $\mathrm{O}=$ no; $1=y e s$. Religious activity: $\mathrm{O}=$ no frequent attendance at church/temple/mosque; $1=$ frequent attendance at church/temple/mosque.

Looking at the correlations between the determinants for reactions to gene technology and the demographic variables (Table 2), we notice that men have a more positive perception of gene technology, and people with higher levels of education and those who are more religious have more negative perceptions. Generally, younger people, people with higher levels of education, and those who are less religious have more knowledge about gene technology. Older people trust the actors less, people with higher levels of education have more personal interest in gene technology, and women and younger people have more experience with gene technology (all $r$ values are between .06 and .32). 
Table 2.

Results for the predicting variables $(\mathrm{n}=1010)$, and correlations with demographic variables

\begin{tabular}{|c|c|c|c|c|c|}
\hline \multirow[t]{2}{*}{ Construct } & \multirow{2}{*}{$\begin{array}{l}\text { Description and Items of } \\
\text { Scale }\end{array}$} & \multicolumn{4}{|c|}{ Correlation with Demographic Variables ${ }^{a}$} \\
\hline & & $\begin{array}{l}\text { Gender Age } \\
\text { (male) }\end{array}$ & Education & $\begin{array}{l}\text { Having } \\
\text { Children }\end{array}$ & $\begin{array}{l}\text { Being } \\
\text { Religious }\end{array}$ \\
\hline Perception of gene technology & $\begin{array}{l}5 \text {-point scale }(1-5) \\
\alpha=.80 ; M=3.08 ; s d=.64\end{array}$ & $-* * *$ & $t^{* *}$ & & $+* *$ \\
\hline
\end{tabular}

Human cloning

Obligatory genetic tests for insurance

Genetically changing animals for food production

The use of gene technology to simplify food production

$\mathrm{Gm}$-crops to decrease environmental impact

Use of embryo tissue to research treatment of diseases

Storing DNA in databases

GM-crops to counter food allergy

Modifying rice for dry areas

Use of gene technology against intestinal cancer

Mapping DNA to prevent diseases

Knowledge about gene

technology

2-point scale (incorrect -

\begin{aligned} & \hline$+^{*} \quad-* * *+^{* * *} \\ & \\ &$\hline$-* *\end{aligned}$

The chimp is the animal species genetically closest to mankind

correct answer)

$\mathrm{M}=.65 ; \mathrm{sd}=.25$

If someone has an increased risk of a hereditary disease, his or her children will also have this risk

Only genetically modified bacteria have genes, whereas normal bacteria don't

Plants have some of the same genes as human beings

Trust in actors
$\begin{aligned} & \text { 5-point scale }(1-5) ; \\ & \alpha=.71 ; M=3.16 ; s d=.60\end{aligned}$

As an information source; family doctor/specialist

As an information source: scientists

As an information source: science/health documentaries on television

As an information source: news and current affairs programmes on television

As an information source: newspapers

As an information source: government service announcements

Trust in compliance with legislation on genetic research

Trust in supervision by the government 
Table 2. (continued)

\begin{tabular}{|c|c|c|c|c|c|}
\hline \multirow[t]{2}{*}{ Construct } & \multirow{2}{*}{$\begin{array}{l}\text { Description and Items of } \\
\text { Scale }\end{array}$} & \multicolumn{4}{|c|}{ Correlation with Demographic Variables ${ }^{a}$} \\
\hline & & $\begin{array}{l}\text { Gender Age } \\
\text { (male) }\end{array}$ & Education & $\begin{array}{l}\text { Having } \\
\text { Children }\end{array}$ & $\begin{array}{l}\text { Being } \\
\text { Religious }\end{array}$ \\
\hline $\begin{array}{l}\text { Personal interest in gene } \\
\text { technology }\end{array}$ & $\begin{array}{l}\text { 4-point scale }(1-4) ; \\
\alpha=.68 ; M=2.72 ; s d=.51\end{array}$ & & $+* * *$ & & \\
\hline \multicolumn{6}{|c|}{ DNA identification for forensic purposes } \\
\hline \multicolumn{6}{|l|}{ Diseases and their treatment } \\
\hline \multicolumn{6}{|l|}{ Genetic research and heredity } \\
\hline \multicolumn{6}{|l|}{ GM-food } \\
\hline \multicolumn{6}{|l|}{ Genetic modification } \\
\hline \multicolumn{6}{|l|}{ Cloning } \\
\hline Experience with gene technology & $\begin{array}{l}\text { 2-point scale (yes - no); } \\
\alpha=.64 ; M=.14 ; s d=.30\end{array}$ & & & & \\
\hline \multicolumn{6}{|c|}{ Have ever been offered genetic tests or genetic research } \\
\hline Have recently been offered a genet & tic test & & & & \\
\hline
\end{tabular}

${ }^{*} \mathrm{p}<.05 .{ }^{* *} \mathrm{p}<.01 .{ }^{* * *} \mathrm{p}<.001$. (all 2-tailed significant levels). $\mathrm{M}=$ mean item score.

${ }^{a}$ Gender: $\mathrm{O}=$ female; $1=$ male. Age: 17-19; 20-39;40-64; 65-79; 80+. Education: $1=$ low level; $2=$ medium level; $3=$ high level. Having children: $0=$ no; $1=y e s$. Religious activity: $0=$ no frequent attendance at church/temple/mosque; $1=$ frequent attendance at church/temple/mosque.

\subsubsection{Testing a Generic Model Describing the Reactions to Gene Technology}

The model visualised in Figure 1 was tested using AMOS 5.0 (Byrne, 2001)3). This model hypotheses that experience, interest, knowledge, the perception of gene technology, and trust are determinants of the intention to buy gene-tech products, concern about abuse, and desired influential actors. The parameters were estimated using the maximum-likelihood (ML) method. The analysis was carried out for scale means, and the measurement error was not included, meaning that the path analysis version of the SEM was used (Kline, 2005).

The results show that the generic model provides a plausible explanation of the public's reaction to gene technology $(\mathrm{RMSEA}=.020 \text {; chi-square }=17.98, \mathrm{df}=14, \mathrm{p}=.21 ; \mathrm{CFI}=.989 ; \mathrm{SRMR}=.028)^{4}$. All paths were found to be significant and the signs of the path coefficients were all in the expected direction.

The variables in the model explained $27 \%$ of the variance in the intention to buy gene-tech products. The perception of gene technology was the main determinant $(\beta=-.45, t=13.56)$. However, trust $(\beta=.12, t=3.67)$, knowledge $(\beta=.11, t=3.28)$ and personal interest $(\beta=.09, t=2.75)$ also explained significant portions of the variance.

The perception of gene technology was explained to a lesser degree (8\%). There was one highly 
significant determinant: trust in actors $(\beta=-.26, \mathrm{t}=7.19)$. Personal interest in gene technology $(\beta=.10, t=2.66)$ also contributed significantly to the prediction of the perception of gene technology.

The explained variance in all other endogenous variables was less than $5 \%$. For the concern about abuse, the explained variance amounted to $4 \%$. Trust in actors $(\beta=-.12, \mathrm{t}=-3.17)$, perception of gene technology $(\beta=.11, \mathrm{t}=2.89)$ and personal interest in gene technology $(\beta=.10, \mathrm{t}=2.62)$ were all found to be statistically significant determinants.

Figure 1.

Results of Testing the Generic Model ${ }^{\mathrm{a}}$

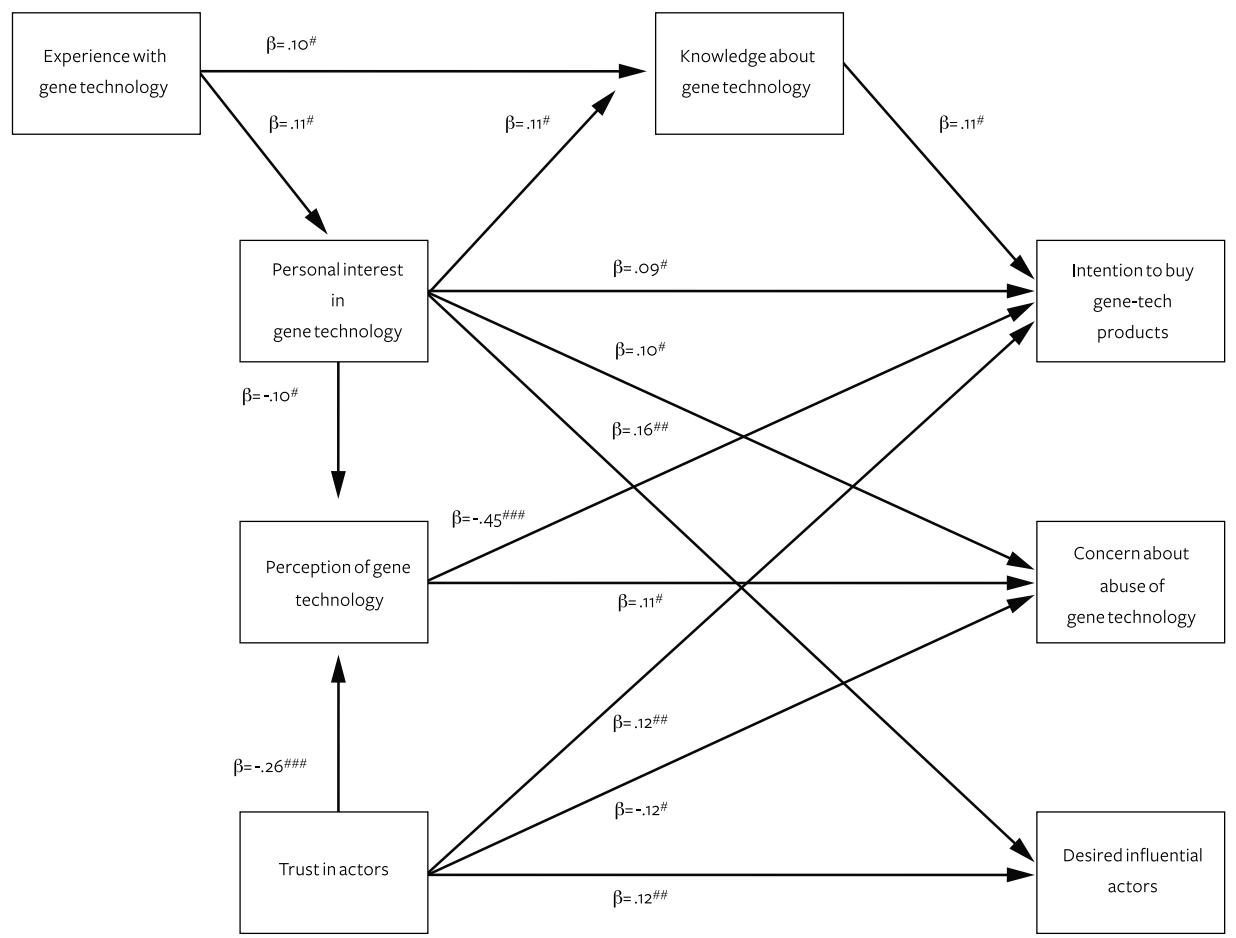

${ }^{a} \mathrm{RMSEA}=.020 ;$ chi-square $=17.98, \mathrm{df}=14, \mathrm{p}=.21 ; \mathrm{CFI}=.989 ; \mathrm{SRMR}=.028 . \# \mathrm{p}<.05 ; \# \# \mathrm{p}<.001, \# \# \# \mathrm{p}$ extremely small $(6.0<\mathrm{t})$

The explained variance in desired influential actors was also small (4\%). Personal interest ingene technology $(\beta=.16, \mathrm{t}=4.37)$ and trust in actors $(\beta=.12, \mathrm{t}=3.37)$ were both highly significant determinants. The explained variance in the knowledge about gene technology (3\%) and personal interest in gene technology (1\%) were small. All hypothesised determinants were found to be statistically significant. 


\subsection{Discussion}

The aim of this study was to identify some building blocks for a model of public reactions to applications of gene technology. Previous studies have focused on single-application models, but a more generic model describing the underlying determinants for reactions to various gene technologies has not yet been developed. Using the data available in this survey, we have made a first attempt at presenting such a generic model.

This model shows that it is possible to identify the determinants that lead individuals to form a perception related to gene technology and act accordingly. However, some limitations have to be mentioned. The quality of measurement is crucial in predictive analyses and theoretical modelling. In this study, the constructs were operationalised according to items used in prior research (IBT Marktonderzoek, 2002). Although most scales have acceptable internal consistencies, the measuring instruments were not specifically designed for the path analyses we performed.

The path model gives a plausible explanation of the relationship between various dependent and independent variables in the model. All hypothesised paths were significant, and the signs of the path coefficients were as expected.

We found that experience and knowledge played a negligible role. Neither of these variables directly predicted the perception of gene technology. Experience predicted a small percentage of the variance in interest and knowledge, but it was not significantly related to any of the three reactions: buying intention, concern, and desired influence. Knowledge, however, did significantly predict buying intention, but had no significant relationship with concern and desired influence. This is in accord with Bauer and Gutteling's (2006) findings. Personal interest is significantly related to all three dependent variables, with betas ranging from .o9 to 16 .

We observed more pronounced results for the role of the factor trust; trust does correlate with the perception of gene technology, as well as to all three dependent variables. The largest path coefficients were those predicting the buying of gene-tech products from the perception of gene technology $(\beta=-.45, t=13.56)$, and predicting the perception of gene technology from trust in actors $(\beta=-.26, \mathrm{t}=7.19)$. The model can be summarised as follows: People develop a perception of gene technology based on their trust in relevant actors in the field, and this affects their intention to buy gene-tech products. These findings correspond to the literature reviewed earlier (Frewer et al. 1996; Hansen, Holm, Frewer, Robinson \& Sandoe, 2003; Peters, Covello \& McCallum, 1997; Slovic, 2000; Trumbo \& McComas, 2003).

An important question with the model we analysed concerns the direction of causality between variables such as the perception of gene technology and concern about abuse. In the path analysis, the fact that a model fits the data does not mean that it is the only fitting model. The plausibility of agiven model needs to be determined by evaluating other hypothetical models that might explain the data. We tested a model in which the concern about abuse predicted the perception of gene technology. This model fit the data almost equally as well as the model in which the perception of gene technology predicted the concern about its abuse ${ }^{5)}$. We also tested a model in which the 
concern about abuse determined the interest in gene technology. This model also provided a plausible representation of the data ${ }^{6}$.

A final issue that needs to be addressed is whether a generic model for reactions to gene technology can be used as a framework to structure determinants for specific applications of gene technology. Are the results applicable to various fields of gene technology, or are they specific to particular applications? From this research we conclude that a generic model for reactions to gene technology can be stated. In this model, three separate reactions to gene technology are represented where the socio-psychological process can be structured in a general way. Further research should investigate if general models like these can in fact be applicable to the public response on other new technologies and other domains. Also, one would expect other determinants, like involvement, lifestyle, or media influence to play a substantial role in this process. Exploring the whole range of determinants in more detail will increase our understanding of the public reactions to the development of emerging technologies.

\section{Acknowledgments}

This articleis based on researchfunded bythe CentreforSocietyand Genomics-The Netherlands, a national centre funded by the Netherlands Genomics Initiative.

\section{Notes}

1. The authors particularly refrained from identifying the trust determinant included in our model as either strictly cognitive or affective, but referred to the broad discussion on the role and character of trust (Frewer, et al, 2003; Tanaka, 2004).

2. Overall, no major differences for the variables reported in this study were found between 2002 and 2005 (IBT Marktonderzoek, 2002).

3. The net response of completed and usable interviews for statistical analysis with Amos was 725. The dropout can be attributed to randomly-missing data. List-wise deletion led to excluding 285 incomplete cases. The demographic make-up of the 725 is comparable to the 1010 participants.

4. Many different indices can be used to assess model fit. Following Kline (2005), we reported four indices: RMSEA, which has been recognized as one of the most informative criteria (Byrne, 2001), chi-square, CFI, and SRMR. The following criteria were used: RMSEA: when RMSEA is below .08, the model fit is acceptable and when RMSEA is below .05, the fit is good; CFI: when CFI is higher than .90, the model is acceptable; SRMR: values of less than .10 are favourable; and Chi-square: when the significance level of chi-square is larger than .05, the model is acceptable. It should be noted, that there are problems attached to the use of chi-square, and that the main reason for reporting the coefficient is because many other fit statistics depend on it 
(Kline, 2005).

5. $\quad$ RMSEA $=.020 ;$ chi-square $=17.94, \mathrm{df}=14, \mathrm{p}=.21$; $\mathrm{CFI}=.989 ; \mathrm{SRMR}=.028$

6. RMSEA $=.024$; chi-square $=20.06, \mathrm{df}=14, \mathrm{p}=.13 ; \mathrm{CFI}=.983$; $\mathrm{SRMR}=.029$ 


\section{References}

Bauer, M.W., \& Gutteling, J.M. (2006) Issue salience and media framing over 30 years. In: G. Gaskell \& M.W. Bauer (eds), Genomics and Society. Legal, ethical and social dimensions. London: Earthscan, 113-130.

Bandura, A. (1989) Human Agency in Social Cognitive Theory. American Psychologist, 44(9), 1175-1184.

Byrne, B. M. (2001) Structural Equation Modelling with AMOS: Basic concepts, applications and modelling. Mahwah, New Jersey / London: Lawrence Erlbaum Associates.

Cuite, C. L., Aquino, H. L., \& Hallman, W. K. (2005) An empirical investigation of the role of knowledge in public opinion about GM food. International Journal of Biotechnology, 7(1-3), 178-194.

Dowling, G. R., \& Staelin, R. (1994) A Model Of Perceived Risk And Intended RiskHandling Activity. Journal OfConsumer Research, 21(1), 119-134.

Finucane, M. L., \& Holup, J. L. (2005) Psychosocial and cultural factors affecting the perceived risk of genetically modified food:an overview of the literature. Social Science\&Medicine, $60(7), 1603-1612$.

Frewer, L. J., Scholderer, J., \& Bredahl, L. (2003) Communicating about the risks and benefits of genetically modified foods: The mediating role of trust. Risk Analysis, 23(6), 1117-1133.

Frewer, L. (2004) The public and effective risk communication. Toxicology Letters, 149(1-3), 391-397.

Frewer, L., Howard, C., Hedderley, D., \& Shepherd, R. (1996) What determines trust in information about food-related risks? Underlying psychological constructs. Risk Analysis, 16(4), 473-486.

Gaskell, G., Allansdottir, A., Allum, N., Corchero, C., Fischler, C., Hampel, J., et al. (2006) Europeans and Biotechnology in 2005: Patterns and Trends (No. Eurobarometer 64.3). London: Centre for the study of Bioscience, Biomedicine, Biotechnology and Society.

Gaskell, G., Allum, N., Wagner, W., Kronberger, N., Torgersen, H., Hampel, J., et al. (2004). GM foods and the misperception of risk perception. Risk Analysis, 24(1), 185-194.

Grunert, K. G., Bredahl, L., \& Scholderer, J. (2003) Four questions on European consumers' attitudes toward the use of genetic modification in food production. Innovative Food Science and Emerging Technologies, 4(4), 435-445.

Gutteling, J.M. (2005) Mazur's Hypothesis on Technology controversy and Media. International Journal of Public Opinion Research, 17 (1), 23-41.

Gutteling, J., Hanssen, L., van der Veer, N., \& Seydel, E. (2006) Trust in governance and the acceptance of genetically modified food in the Netherlands. Public Understanding of Science, 15(1), 103-112.

Hansen, J., Holm, L., Frewer, L., Robinson, P., \& Sandoe, P. (2003) Beyond the knowledge 
deficit: recent research into lay and expert attitudes to food risks. Appetite, 41(2), 111-121.

Henneman, L., Timmermans, D. R. M., \& van der Wal, G. (2004) Public experiences, knowledge and expectations about medical genetics and the use of genetic information. Community Genetics, 7(1), 33-43.

Horst, M., Kuttschreuter, M., \& Gutteling, J. M. (2007) Perceived usefulness, personal experiences, risk perception and trust as determinants of adoption of e-government services in The Netherlands. Computers in Human Behavior, 23(4), 1838-1852.

IBT Marktonderzoek, (2002). Publieksenquête Genomics: Stichting Consument en Biotechnologie.

Kline, R.B. (2005). Principles and practice of structural equation modeling. New York: The Guilford Press.

Lazarus, R. S. (1993) Coping Theory and Research - Past, Present, and Future. Psychosomatic Medicine, 55(3), 234-247.

Leshner, A.I. (2005) Where science meets society, Science, 307, 815.

Moerbeek, H., \& Casimir, G. (2005) Gender differences in consumers' acceptance of genetically modified foods. International Journal of Consumer Studies, 29(4), 308-318.

Moon, W., \& Balasubramanian, S. K. (2004) Public attitudes toward agrobiotechnology: The mediating role of risk perceptions on the impact of trust, awareness, and outrage. Review of Agricultural Economics, 26(2), 186-208.

Mucci, A., Hough, G., \& Ziliani, C. (2004) Factors that influence purchase intent and perceptions of genetically modified foods among Argentine consumers. Food Quality and Preference, 15(6), 559-567.

Pardo, R., Midden, C., \& Miller, J. D. (2002) Attitudes toward biotechnology in the European Union. Journal of Biotechnology, 98(1), 9-24.

Peters, R. G., Covello, V. T., \& McCallum, D. B. (1997) The Determinants of Trust and Credibility in Environmental Risk Communication: An Empirical Study. Risk Analysis, 17(1), 4354 .

Pin, R. R., \& Gutteling, J. (2006) The development of Public Risk Perception Research in the Genomics field. An empirical analysis of the Literature in the Field. Paper presented at the conference of the Society for Risk Analysis - Europe, Ljubljana, Slovenia, 11-13 September 2006.

Pin, R. R., \& Gutteling, J. M. (2005) Publieksonderzoek Genomics 2005. Nijmegen, The Netherlands: Centre for Society and Genomics.

Shaw, A. (2002) "It just goes against the grain." Public understandings of genetically modified (GM) food in the UK. Public Understanding of Science, 11, 273-291.

Siegrist, M. (1999) A causal model explaining the perception and acceptance of gene technology. Journal of Applied Social Psychology, 29(10), 2093-2106.

Siegrist, M. (2000) The influence of trust and perceptions of risks and benefits on the acceptance of gene technology. Risk Analysis, 20 (2), 195-203.

Slovic, P. (2000) The perception of risk. London: Earthscan Publications.

Slovic, P., Finucane, M. L., Peters, E., \& MacGregor, D. G. (2004) Risk as analysis and risk as feelings: Some thoughts about affect, reason, risk, and rationality. Risk Analysis, 24(2), 311322.

Statistics Netherlands (2006). Statistical Yearbook 2006. Voorburg/Heerlen, The Netherlands: CBS.

Tanaka, Y. (2004) Major psychological factors affecting acceptance of gene- 
recombination technology. Risk Analysis, 24(6), 1575-1583.

Townsend, E, \& Campbell, S. (2004) Psychological determinants of willingness to taste and purchase genetically modified food. Risk Analysis, 24 (5), 1385-1393.

Trumbo, C. W., \& McComas, K. A. (2003) The Function of Credibility in Information Processing for Risk Perception. Risk Analysis, 23(2), 343-353.

Urban, D. (1996) Quantitative measurement of public opinions on new technologies - An application of SEM-methodology to the analysis of beliefs and values toward new human applications of genetic engineering. Scientometrics, 35(1), 71-92. 


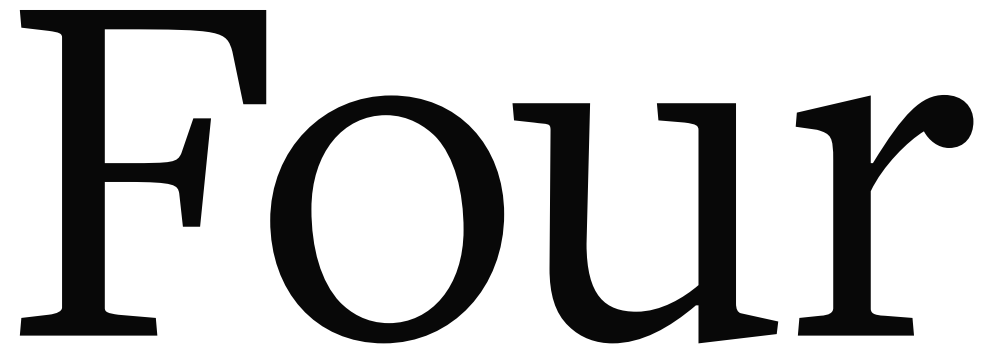

Understanding Public

Perceptions of Personalised

Nutrition - A Comparison

of Australia and The

Netherlands

Renske R. Pin

Christine R. Critchley

Elizabeth A. Hardie

Submitted 


\section{Abstract}

If genomics technology can be used to predict diseases and prescribe preventive diets based on a person's genetic profile, it is important to understand the public's intention to adopt such personalized diets. While the existing literature suggests several factors influence the adoption of personalizes diets, the process leading to intention to change one's diet based on a genetic test remain unclear. This study examines how affective evaluations, rational cognitions, and social trust influence individuals' intentions to adopt personalized nutrition plans. We draw on data from representative community samples in The Netherlands $(n=2109)$ and Australia $(n=1000)$, and use structural equation modeling to explore the process of forming such intentions. Although the final model showed a good fit in both populations, an important cross-cultural difference emerged. Among Australians, positive emotion was a substantial predictor of the intention to adopt a personalized nutrition program, while among the Dutch, rational considerations were more important predictors. A possible explanation could be that individuals from countries where information is provided (i.e., the Dutch) are more likely to base their intention on rational considerations, while those given less information (i.e., Australians) rely on affective evaluations.

Keywords:

public perception, trust, genomics, personalized nutrition, structural equation modeling 


\section{Four}

\author{
Understanding Public Perceptions of Personalised
}

Nutrition - A Comparison of Australia and The

Netherlands

\subsection{Introduction}

The technology of nutrigenomics focuses on the relationship between human nutrition and human genetics in order to maintain and promote health and to prevent the occurrence of disease (Afman \& Muller, 2006). One of the potential applications of this new technology is personalized nutrition, defined as tailored dietary advice that helps consumers select foods that are optimally aligned with their genetic makeup. This promising new technology could have important public health benefits, but may also have some disadvantages. The technology associated with nutrigenomics may raise consumer concerns about how human genetics research can compromise the integrity of nature, privacy issues, and control over sensitive information. Canadian research, for example, found that food-related genomics research evoked strong reactions to the genetic modification of crops. Such reactions are inevitable and suggest that we should pay substantial attention to public expectations and concerns about the potential deliverables of nutrigenomics (Ronteltap, van Trijp, Renes, \& Frewer, 2007).

The field of personalized nutrition is still in its infancy. Scholars in the nutrition field differ considerably in their optimism regarding personalized diets, and it is still unclear how spinoffs of nutrigenomics such as personalized nutrition will take shape (Ronteltap, Van Trijp \& Renes, 2008). Despite the large amount of uncertainty about the development and success of personalized nutrition in the near future, genetic scientists agree that it has substantial potential to improve public healthcare (Afman \& Muller, 2006). To make the most of this potential, the public can play a role in developing the innovation of personalized nutrition, as the public has the power to adopt or reject new technology (Ronteltap, van Trijp, \& Renes, 2007). Public acceptance and intention to adopt a new genetic technology is a necessary precondition for its success. In light of European experiences with the controversial introduction of genetically modified (GM) foods, the potential introduction of nutrigenomics needs to be carefully examined. This paper examines intentions to adopt nutrigenomics, or more specifically, personalized nutrition, as well as the role of three determinants that may influence a person's intention to adopt genomics technology: social trust, rational cognitions and affective evaluations. We developed, tested and cross validated a model including all three determinants. Further, we explored differences in the process of acceptance of personalized nutrition in two countries that differ substantially in the information provided on the technology, Australia and The Netherlands.

Prior research has looked at a range of factors that influence public perception of food innovations (e.g., Ronteltap, van Trijp, Renes, \& Frewer, 2007), and several of these studies combine a range of factors in one model (Pin \& Gutteling, 2008). However, few published analyses comprehensively 
examine peoples' intentions to adopt personalized nutrition. Little is therefore known about whether the public would support or oppose personalized nutrition, and what factors predict these intentions.

\subsubsection{Predicting the Intention to Adopt Personalized Nutrition}

Since we know little about the public's intention to adopt personalized nutrition, the public's reactions to the possibility of a personalized diet are of interest because most people have not yet crystallized their attitudes about this phenomenon. Respondents are generally unfamiliar with nutrigenomics, which makes it a difficult topic for survey research. However, the intention to adopt personalized nutrition may be driven by two familiar processes that must be undertaken in order to adopt personalized nutrition. First, since a personalized diet is based on personal genetic information, a person should be willing to take a genetic test and reveal his or her genetic profile to predict possible future diseases. Second, a person should be willing to adopt a diet based on his or her genetic makeup to prevent future diseases. These were intentions assessed in the current study regarding adoption of personalized nutrition.

When predicting behavioral intention, attitudes towards the behavior are important determinants. Literature on public perceptions in genomics (Pin \& Gutteling, 2008) focuses on predictors such as trust, beliefs, cost/benefit perception, and affect. Ronteltap, van Trijp, Renes, and Frewer (2007), for example, offer a theoretical framework and argue that at a proximal level, consumer acceptance of nutrigenomics is determined by perceived costs and benefits, perceived risk and uncertainty, subjective norms, and perceived behavioral control. Their literature review showed previous research in general has looked at either trust, rational cognitions such as cost/ benefit perceptions or affective evaluations, but not combined in one model.

Many studies on the prediction of behavior from attitudinal variables were conducted in the framework of the theory of planned behavior (TPB; Ajzen 1991). According to the TPB, people act in accordance with their intentions and perceptions of control over the behavior, while intentions in turn are influenced by attitudes toward the behavior, subjective norms, and perceptions of behavioral control. The cognitive foundations of these factors are consistent with an expectancy-value formulation (Ajzen, 2001). Support for the theory in general is summarized in a meta-analysis (Armitage \& Conner, 2001), literature review (Sutton, 1998), and another review which summarizes its application to health-related behavior (Conner \& Sparks, 1996).

This more rational component of attitudes is argued to be an important predictor of intentions, especially in the case of science and technology, and typically important for "familiar" or well known attitude objects. A dominant view with new science is the deficit model. This is based on the assumption that it is a lack of public understanding or knowledge that has led to the present climate of skepticism toward science. In this formulation, it is the public that is assumed to be "deficient", while science is "sufficient". The public's doubts about the value of scientific progress or fears about new or unfamiliar innovations, such as genetically modified organisms, are due to ignorance of the science behind them. Lacking a proper understanding of the relevant facts, people fall back on mystical beliefs and irrational fears of the unknown. If one accepts this 
hypothesis, the obvious implication for science policy is that public information campaigns should be instigated to remedy the public's disenchantment with science (Sturgis \& Alllum, 2004).

Inherent in the expectancy-value model of attitude is the assumption that evaluative judgments are the result of cognitive processes: associations between the attitude object and valued attributes. Some theorists have challenged this assumption, proposing that evaluations may also be controlled by affective processes (Ajzen, 2001). In fact, the affective primacy hypothesis (Zajonc 1980) assigns precedence to affect over cognition. An alternative and by far more popular position is based on the multi-component view of attitude and assumes that evaluations are influenced by cognition as well as affect (see Eagly \& Chaiken 1993, van der Pligt et al 1998). Depth-of-information-processing theories such as the Elaboration Likelihood Model, proposes that there are two routes to persuasion, the "central"route and the "peripheral"route (Petty \& Cacioppo, 1986). The central route involves cognitive elaboration of the issue under consideration and is thought to result in attitude change that is more enduring, resistant to counter-persuasion and predictive of behavior. The peripheral route utilizes external cues (such as information source) to permit simple inferences of the merits of the content to be made without using complex processing of the information itself. There is substantial support for the model in social psychological literature (Eagly \& Chaiken, 1993). If the model holds, a certain level of trust or credibility of institutions providing information on new technologies can be viewed as a necessary precondition for providing information with the intention of changing attitudes (Frewer, Scholderer \& Bredahl, 2003). It has often been assumed that acceptance of new technologies is based to great extent on public perceptions of the associated risks, and that the perception of risk is influenced by trust in the information provided by different information sources (Frewer, Scholderer \& Bredahl, 2003).

In line with the theoretical approaches outlined above, the present study examined the role of cognitive, affective and trust factors in how the publicforms intentions to adopt new technologies. The following sections outline the concept of rational cognitions, along with the more heuristic or automatic drivers of attitudes: social trust and affective evaluations.

\section{Rational Cognitions}

Rational cognitions such as perceptions about the consequences of a behaviour are important factors in how people respond to the behavior. Perceptions of costs (or risks), benefits, and outcomes are important determinants of reactions to new technologies (Gaskell et al, 2004; Ronteltap, van Trijp, Renes, \& Frewer, 2007). Public perception has been frequently studied in relation to new technologies, especially in cases where the technology could be associated with risks (Ronteltap, van Trijp, Renes, \& Frewer, 2007; Slovic, Peters, Finucane, \& MacGregor, 2005). If individuals perceive a benefit from a behavior or choice, the risk associated with this behavior or choice is perceived to be lower (Frewer et al., 2004). If appropriately applied, health technologies such as personalized nutrition may greatly enhance existing models of health intervention. However, potential adverse consequences could arise, such as issues with privacy, confidentiality, and security; quality and effectiveness; sustainability; and the technology divide (Eng, 2004; Meijboom, Verweij, \& Brom, 2003). Attitudes toward engaging in behavior are seen as determined by beliefs about the outcomes of performing the behavior, weighted by the public's 
subjective evaluation of these expected outcomes (Verdurme \& Viaene, 2003). When considering cost/benefit perception measurement, many studies have focused on the cost or risk perception of a new technology (e.g., Slovic et al., 2005). Alhakami and Slovic (1994) were among the first to explore the generally robust, inverse relationship between the perceived risks and benefits of various technologies. There is debate as to whether they are represented by one dimension or two. Some focus group research indicates that the public does not necessarily differentiate between risks and benefits when it comes to applications that are relatively unknown, such as biotechnology in general (Bredahl, 2001). Costa-Font and Mossialos' (2007) results from a UK sample of the Eurobarometer survey suggest that risk and benefit perceptions are not independent and appear both endogenously and simultaneously determined. Risks and benefits can be seen as two separate concepts, where technology can have both costs and benefits that can be considered separately. Few studies have simultaneously considered both perceived costs and benefits (e.g., Poortinga \& Pidgeon, 2005) or examined perceptions of specific consequences of the technology. The present study attempts to measure the relative influence of costs and benefits by weighing both the pros and cons of a technology to provide a relative measurement or overall evaluation of cost and benefit perceptions. Further, we will assess perceptions of the consequences of the technology.

\section{Social Trust}

Trust has been frequently identified as a determinant of perceptions of and reactions to gene technology (Frewer, Scholderer, \& Bredahl, 2003; Tanaka, 2004). Social trust refers to people's willingness to rely on experts and institutions when managing risks and technologies. According to Siegrist, Cvetkovich and Roth (2000), social trust is "the willingness to rely on those who have the responsibility for making decisions and taking actions related to the management of technology, the environment, medicine, or other realms of public health and safety" ( $p$ 354). Because the public generally has limited information, ability or time to understand the complexities of new or advanced technologies, they have to rely on information obtained from experts.

Trust in regulators, science, and industry is particularly important when the public perceives itself as having no control over a particular event or activity, or has limited information. In this situation, the public has to leave the responsibility for ensuring consumer protection or public welfare to others, which is arguably the case with respect to gene technology (Frewer, 2004). Frewer, Howard, Hedderley, and Shepherd (1996) found that information sources are associated with different characteristics that influence the extent to which they are trusted by the public. Expertise byitselfdoes not lead to trust, butinstead must be accompanied byother characteristics such as accountability. Sources with a moderate degree of accountability are trusted more than those with complete freedom (Finucane \& Holup, 2005).

Support for new technology is associated with the level of social trust an individual places in the organization and/or the individuals who have created the technology. Slovic (1999) argues that lack of trust is one of the reasons that the public often rejects scientists' risk assessments. Social relationships of all types, including those related to risk management, rely heavily on trust. In fact, the limited effectiveness of risk communication efforts can be at least partially attributed to a lack of trust. If one trusts the risk manager, for example, communication is relatively easy. 
When trust is lacking, though, no form or process of communication will be satisfactory.

Thus, acceptance of a new or complex technology will depend on the level of trust the public has in the companies, scientists, governments or organizations associated with developing and regulating the technology. Critchley and Turney (2004) found a strong and significant indirect effect of trust on public comfort with stem cell research. In that study, people with higher levels of trust were more comfortable with stem cell research because they were more likely than their counterparts to believe that science is valuable.

Increased trust in regulators in the gene technology field has been consistently associated with a decrease in the perceived risk and an increase in the perceived benefit of new technologies (e.g., Frewer, 2004; Siegrist, 2000). A model posited by Siegrist et al. (2000) states that shared values determine social trust in institutions and persons related to a technology: A model posited by Siegrist et al. (2000) states that shared values determine social trust in institutions and persons related to a technology: Trust in an institution will be high if the institution is perceived to embody similar salient values to the trustor. Furthermore, it was found that social trust has a positive influence on perceived benefits and a negative impact on perceived risks. Tanaka's (2004) study, for example, which is based on Siegrist et al.'s model (2000), suggests that acceptance of generecombination technology, whether applied to plants, animals, or human beings, is explained largely by perceived risks, perceived benefits and trust. Trust was particularly important when the technology was proposed to be used for human beings, as it was indirectly related to acceptance through perceived risks and benefits. Tanaka (2004) tested a structural equation model where trust was found to have an indirect influence on the acceptance of human generecombination technology through perceived risk and perceived benefit, and found that the proposed model fit the data well. When people trust the information they receive from those in the scientific and medical fields, they will be receptive to the benefits that a technology can offer them, contributing to public support for the new technology.

Different views exist on how trust relates to cost and benefit perceptions. Many social scientists have argued that trust has a crucial role in the process of new technology acceptance (Frewer et al., 2004; Slovic, 1999). However, there has been some resistance to this idea (Sjöberg, 2001). Sjöberg, for example, argued that trust only weakly relates to risk perception, and found that beliefs about the unknown effects of a technology, i.e., the knowledge that there are unknown effects, are a much stronger predictor of risk perception. In the case of nutrigenomics, there is a relevant history of genetically modified (GM) food. The life sciences business, integrating agrichemicals, GM foods and pharmaceuticals, became one of the industrial and scientific visions for the twenty-first century. Concurrently, however, European governments, the European Commission and the European Parliament struggled and sometimes clashed over regulatory arrangements (Gaskell, Allum, et al., 2001). The public domain saw an outburst of media coverage from 1996 to 2001 (Bauer \& Gutteling, 2006), episodes of mobilisation in protest against field trials of GM crops, consumer resistance to GM foods, supermarket boycotts and finally, in 1999, a moratorium on the commercial planting of GM crops in the European Union. Dolly the sheep, bull Herman, and the genetically modified (GM) soy boycott stand as icons of these turbulent years. Uncertainty about possible long-term health risks may in this case have added fuel to the fire (Pin \& Gutteling, 2008). That makes the actors in science and medicine 
less trustworthy. The issue of how trust works in the adoption process of a new technology is a prominent question that is not fully understood.

\section{Affective Evaluations}

Affect, or emotional response, is an important factor influencing the decision-making process. The feelings associated with perceived risk, and how these fast, instinctive, and intuitive reactions influence human decision-making have been frequently studied (Slovic et al., 2005; Townsend, 2006). "Affective evaluation" means the specific quality of "goodness" or "badness" (i) experienced as a feeling state (with or without consciousness) and (ii) demarcating a positive or negative quality of a stimulus. Affective responses occur rapidly and automatically. Slovic, Finucane, Peters, and MacGregor (2007) argue that reliance on such feelings can be characterized as "the affect heuristic." Although cognitive analysis is certainly important in some decisionmaking circumstances, reliance on affect is a quicker, easier, and more efficient way to navigate in a complex, uncertain, and sometimes dangerous world.

Alhakami and Slovic (1994) found that an inverse relationship between perceived risk and perceived benefit (i.e.,activities or technologies that are judged high in risk tend to be judged low in benefit, and vice versa) was linked to the strength of positive or negative affect associated with that activity. This result implies that people base their judgments of an activity or technology not only on what they think about it but also on what they feel about it. If they judge the risks as low and the benefits as high, they feel positive about an activity; if instead they tend to judge risks as high and benefits low, then they feel negative about it. We expect that the more positive the public feels about the new technology, the more likely they are to have the intention to adopt it.

Figure 1.

Theoretical model predicting intention to use personalized nutrition based on social trust, rational cognitions and affective evaluations.

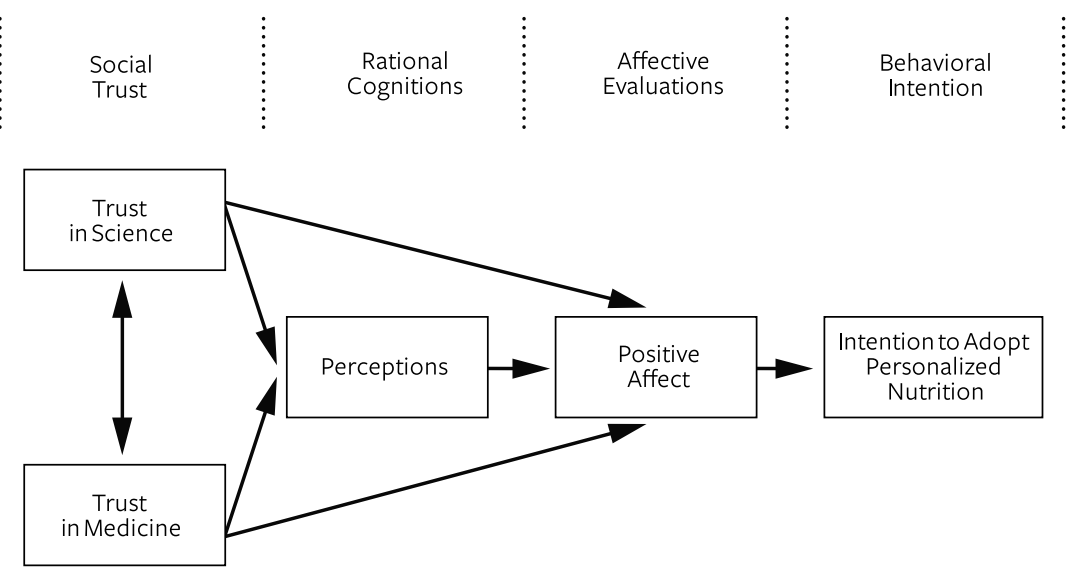




\subsubsection{A Model Predicting the Intention to Adopt Personalized Nutrition}

When predicting the intention to adopt a new technology, the role of trust and affect are important, but so are the more cognitive factors. Limited research has looked at both processes and their conjoint roles. This research will look at both processes in one model. Using previously identified key determinants of public perceptions, such as Siegrist's (2000) work on the determinants trust, cost and benefit perceptions; and intention models such as the Theory of Planned Behavior, the current research developed a model that assessed the influence of three factors, social trust, rational cognitions and affective evaluations on people's intentions to adopt personalized nutrition. The model was tested on samples from two countries, Australia and The Netherlands, in order to explore socio-psychological processes in two national settings.

Based on the available literature, that attitudes towards GM food, genetic testing and dieting are influenced by trust, rational cognitions or perceived consequences of the technology and affective evaluations, we developed a model to predict the public's intention to adopt personalized nutrition. When looking at the relations between the three determinants, it is important to consider the social trust the public has in relation to science and medicine. In the case of genomic technologies, trust in the institutions of science and medicine will play a role, since these institutions are responsible for the development of the technology. The more trust the public has toward these two institutions, the greater benefits and fewer costs they will attribute to the technology and the more positive and desirable they will perceive the consequences of the technology to be. Positive perceptions about a technology are related to positive feelings about it, which will predict the intention to adopt the technology. Figure 1 describes this model showing the pathways from trust to perceptions and affect which lead to intention, one based more on a rational process and one based more on affective evaluation.

In the model developed here, we expect that trust may influence positive feelings, and in turn intentions, in two ways. The first is via the effects trust has on cognitive perceptions. As suggested by Siegrist (Siegrist, 2000; Siegrist, Cvetkovich, \& Roth, 2000), a belief that a technology will be beneficial is dependent upon a high level of trust in those conducting the science (i.e. scientists and scientific institutions) and those administering it (i.e., medical practitioners). If expert opinion is trusted (and assuming this opinion is positively portrayed by the media), the public is more likely to believe the message that personalized nutrition is beneficial. Such a belief will induce a positive feeling about personalized nutrition and in turn increase an intention to adopt it. The second pathway assumes that trust may also increase intention due to a direct effect on positive affect. If trust in expertise is high then feelings about personalized nutrition may become positive regardless of whether or not the benefits are perceived to outweigh the costs. In particular, those with little or no information about personalized nutrition may exclusively base their affective attitude toward it on trust in experts rather than a rational cognitive process.

This study compares The Netherlands, where an extensive debate about gene technology took place in the 1990s, to Australia, a Western country with a comparable culture (Lewis, 2003) and values (Inglehart, Basanez, Deiz-Medrano, Halman, \& Luijkx, 2004), but without the history of political and public controversies and media attention concerning gene technology. A great deal has been written about the "Atlantic Divide" concerning new technologies involving genetics, 
such as biotechnology or the introduction of GM food (Gaskel et al., 2001). In North America, biotechnology (especially medical) has been relatively easily adopted, though in much of Europe it has been the subject of political and public controversy (Gaskel et al., 2001). In Australia, however, the introduction of biotechnology has taken place rather silently. Australia could therefore be considered a possible representative of the midpoint, neutral position between two opposites: the European Union (EU) and the United States (US). We expect people's trust in science to influence both rational cognitions and affective evaluations when forming intentions to adopt new technologies. As the Dutch have more information available to them, they may rely more on rational cognitions when forming intention. The Australians, with less information available, may rely more on heuristic affective evaluations when forming intentions.

\subsection{Method}

\subsubsection{Data Collection and Samples}

In Australia, the data were collected in July 2007 by telephone interviews with a randomly drawn sample of 1000 Australians, aged 18 and older, as part of the Swinburne National Technology and Society Monitor (SNTSM 2007). The response rate was $24.6 \%$. The SNTSM is conducted on an annual basis to monitor public perception of advances in science and technology. Apart from a few exceptions, the sample was representative of the Australian population. There were, however, significantly more female (61\%) than male respondents due to sampling error $\left(\chi^{2}(1)=51.1, \mathrm{p}<.01\right)$. The sample was also slightly over-representative of older respondents. Ages ranged from 18 to 91 , and the mean age was 52 years $(s d=16.5)$. In terms of education, $36 \%$ of respondents had a high level of formal education (i.e., university or postgraduate degree), $35 \%$ had intermediate levels of education (i.e., year 12 secondary school or TAFE diploma), and $29 \%$ reported a lower educational level (i.e., less than year 12 secondary school). In Australia, 37.4\% of the respondents said that they had previously heard of personalized nutrition based on genetic makeup. In addition, $5.5 \%$ said that they had been genetically tested.

In The Netherlands, the data were collected in October 2007 via an online panel survey consisting of 5000 households. These households were representative of the Dutch population. From this, a random sample was taken of 2109 Dutch individuals aged 18 and older. The survey questions were presented to these individuals as part of a monthly questionnaire that they participate in. Apart from a few exceptions, the sample was representative of the Dutch population, matching the proportions of the Statistical Yearbook 2007 (Statistics Netherlands, 2007). The proportion of female participants was significantly larger than the proportion of male respondents $(55 \%$ and $45 \%$ respectively; $\left(\chi^{2}(1)=16,9, p<.01\right)$. Respondents ranged in age from 18 to 85 years, with a mean of 46 years $(s d=14.8)$. About $30 \%$ of respondents had a high level of formal education (i.e., $\mathrm{HBO}$ or WO), 34\% had an intermediate level of education (i.e., MBO, HAVO or VWO) and $31 \%$ had a lower educational level (i.e., eighth grade or less, VMBO). In The Netherlands, $26.3 \%$ of respondents said that they had previously heard of personalized nutrition based on genetic structure, and only $1.7 \%$ said that they had been genetically tested. 


\subsubsection{Measures}

In both Australia and The Netherlands, the beginning of the questionnaire included the following: "Scientists say that in a few years they will be able to tell what diseases you are vulnerable to, based on your genetic profile. It may be possible to prevent disease and improve your quality of life by eating the foods that best fit your gene structure." We then asked whether the respondents had heard of personalized nutrition before and whether they had ever had their genetic material tested. All questionnaire item wordings, descriptive statistics and information about internal consistencies can be found in Appendix 1.

\section{Trust in Science and Medicine}

To measure trust in science, we asked respondents to rate the amount of trust they placed in three different actors as sources of information. In Australia, we asked about scientists, universities and Australia's Commonwealth Scientific and Industrial Research Organisation (CSIRO). Respondents had to rate their level of trust on a 6-point scale $(\mathrm{O}=$ don't trust at all, $5=$ trust a very great deal). In The Netherlands, we asked respondents about their trust in researchers/scientists, Government (e.g., Postbus 51) and The Nutrition Centre ( $1=$ no trust, $5=$ trust a very great deal; Australia $\alpha=.65$; The Netherlands $\alpha=.63$ ).

We also measured trust in medicine by asking respondents to rate their amount of trust in three different actors as sources of information. In Australia, we asked about medical specialists, family doctors and hospitals. In The Netherlands, we asked about medical specialists, family doctors and school doctors (Australia $\alpha=.67$; The Netherlands $\alpha=.71$ ).

\section{Rational Cognitions}

Two sets of rational cognitions were measured: perception of costs and benefits and perception of the consequences of personalized nutrition. It was decided to treat these two constructs as separate, given that the beliefs in the consequences of personalized nutrition may not necessarily coincide with an expectation that it will be beneficial, eg people may see personalized nutrition as resulting in a positive consequence but this may not necessarily mean they think it will be benefitial. Similarly, a belief that a negative consequence may not necessarily mean that it will be associated with a belief that personlised nutrition will be costly. Negative consequences may be benefitial and vice versa. We expect these two to be different constructs, but that they are both examples of beliefs that are preceded by a thinking process.

The questionnaire stated that the introduction of the new technology of personalized nutrition based on genetic makeup could have consequences. As a measure of perception of the consequences, or how good things are that are possibly going to happen, the respondents were then asked to rate how desirable or positive each of the following six consequences was on a 5-point scale ( 1 = very undesirable/very negative, 5 = very desirable/very positive): life expectancy would increase, people could live longer; you could know in advance what diseases you are vulnerable to and what diseases you are not; you could be warned to change your eating habits; you could be asked to pay more for life insurance if you do not follow a personalized nutrition plan; every baby's gene structure could be tested for possible diseases; genetic information on every citizen could be stored in DNA banks. Further, to measure the overall perception of costs and 
benefits, we asked respondents to rate the balance of costs and benefits of personalized nutrition based on an individual's genetic material. We based our questions on Poortinga and Pidgeon's (2005) risk and benefit scales. We asked how many costs compared to benefits there would be for themselves, the average Australian/Dutchman, society as a whole and future generations. All four were measured on a 5 -point scale $(1=$ mostly costs, $5=$ mostly benefits $)$.

Factor analysis on the ten items, using principal component analysis with Varimax (orthogonal) rotation, confirmed two separate factors, explaining a total of $60.75 \%$ for the Dutch and $53.62 \%$ for the Australians of the variance for the entire set of variables. Factor 1 was labeled perception of consequences due to the high loadings by the six consequence items. This first factor explained of $35.28 \%$ for the Dutch and $30.84 \%$ for the Australians of the variance. The second factor derived was labeled cost/benefit perception, due to the high loadings by the four cost/benefit items, explaining of $25.47 \%$ for the Dutch and $22.78 \%$ for the Australians of the variance. A moderate level of reliability was found for the scale for perception of consequences (Australia $\alpha=.68$; The Netherlands $\alpha=.69$ ) and a good reliability for the cost/benefit scale (Australia $\alpha=.83$; The Netherlands $\alpha=.92$ ).

As expected, it was found via structural equation modeling (explained further below) that perceived consequences and cost/benefit beliefs were only slightly correlated for both the Dutch $(r=.11, \mathrm{p}<.001)$ and the Australian $(r=.26, \mathrm{p}<.001)$ samples (see Figure 2$)$. The results from this analysis also suggested that the items were represented by two separate underlying constructs.

\section{Positive Affect}

Positive affect was measured with two questions relating to feelings of enthusiasm and comfort towards personalized nutrition based on ones' gene structure. Both were measured on a 5-point scale $(1=$ not at all, $5=$ very much). In the Australian population, a 10-point scale (not at all comfortable - very comfortable) was used for the comfort item (Australia - ; The Netherlands $r$ $=.72, \mathrm{p}<.01)$.

\section{Intention to Adopt Personalized Nutrition}

The intention to adopt personalized nutrition based on genetic tests was assessed with two items. The first question asked for the person's intention to take a genetic test in order to get personalized diet advice. The second question asked for the person's intention to adopt the personalized diet. Although the two items are correlated in both samples (Australia $r=.49, \mathrm{p}<$ .01; The Netherlands $r=.53, \mathrm{p}<.01$ ), they represent different behaviors. Therefore, both items were treated separately in the theoretical model, as opposed to indicators of one factor.

\subsubsection{Data Analysis}

First, we investigated the number of respondents who had missing observations. In the Dutch sample, there were no missing observations. In the Australian survey, respondents had the possibility to answer "don't know" to all questions. The data were tested for missing completely at random (MCAR) using Little's MCAR test (1988). We included all variables in the model as well as gender, education and age. The results showed that the data were not MCAR ( $\chi^{2}(1919)$ 
$=2413.296, p=.000)$. Despite this, the pattern of missing values did not reveal any systematic patterns (overall, there were 108 different missing value patterns). With one exception, there were no significant differences when comparing missing status across all continuous variables. The exception was that older people were more likely to miss the item about consequences regarding life insurance than younger people $(\mathrm{t}(23.1)=-4.3, \mathrm{p}<.001)$. The percentage of missing values was also fairly consistent across gender, age and education. The missing data were therefore considered to be missing at random (MAR). Missing values were therefore replaced for respondents with fewer than $30 \%$ missing across the 20 variables $(n=994)$ using the EM method in SPSS Version 16. A total of 38 multivariate outliers were deleted from the Australian sample and 84 were deleted from the Dutch sample, leaving a total sample of 956 Australian and 2025 Dutch respondents.

\subsection{Results}

\subsubsection{Testing the Structural Equation Model for the Australian and Dutch Population}

The theoretical model presented in Figure 1 was tested via a multi-sample structural equation model (SEM) using EQS Version 6.1 (Bentler, 2006). Correlations between latent variables for both countries can be found in Table 1 . The model in Figure 1 was initially tested using a multi sample analysis. Its structure was identical to that presented in Figure 1, apart from rational cognitions being represented by two latent variables, perceptions of consequences and perceived benefits; and intentions represented by two separate measured variables (see Figure 2). Since multivariate normality was violated in both samples (Mardia's coefficient The Netherlands = 36.29; Australian = 36.56), the Satorra-Benter robust estimation method was used to adjust the parameter estimates for severe negative skewness. The parameter-to-case ratio was acceptable for both samples (Dutch, 74:2025, 1:27); Australia, 74:956, 1:13).

The results showed that the theoretical unconstrained (across countries) model was a borderline fit with the data (Satorra-Benter $\chi^{2}(320)=2342.88, \mathrm{CFI}=.90, \mathrm{NNFI}=.88, \mathrm{RMSEA}=.07,90 \% \mathrm{CI}=$ $.06-$ - 07). The LM test revealed that the chi-square value would significantly drop if the following paths were included in the model: direct paths from consequences to both intention variables were included for the Dutch sample (test: 63.62; diet: 95.11); a direct path from the item 'costs/ benefits to the self' to consequences for the Dutch $(321.20, \mathrm{p}<.001)$, and a direct path from the cost/benefits to the self item to affect for the Australian sample (83.08, $\mathrm{p}<.001)$.

All of these modifications were considered theoretically appropriate and were thus added to the model. Beliefs about consequences may have a direct impact on one's intention to take a test and diet, regardless of whether one feels positively about personalized nutrition. Also an expectation that personalized nutrition could benefit the self could directly influence the belief that it generally has desirable consequences as well as directly influence an individual's affective reaction, independently from an expectation that it may benefit others. After removing all non significant paths, the modified model was found to be a good fit with the data (Satorra-Benter 
$\left.\chi^{2}(318)=1777.89, \mathrm{CFI}=.93, \mathrm{NNFI}=.91, \mathrm{RMSEA}=.06,90 \% \mathrm{CI}=.05-.06\right)$. The parameter estimates for the unconstrained model for both countries are shown in Figure 2.

To test the equivalence of the structural paths across countries, an additional constrained model was computed. This model constrained all structural paths and constrained the two correlations to be equal across groups. The LM test showed that the strength of a number of paths were not statistically equal (all at $\mathrm{p}<.001$ ) across the two countries. These paths are also shown in bold in Figure 2.

Figure 2.

Final multigroup model for Australian and Dutch respondents.

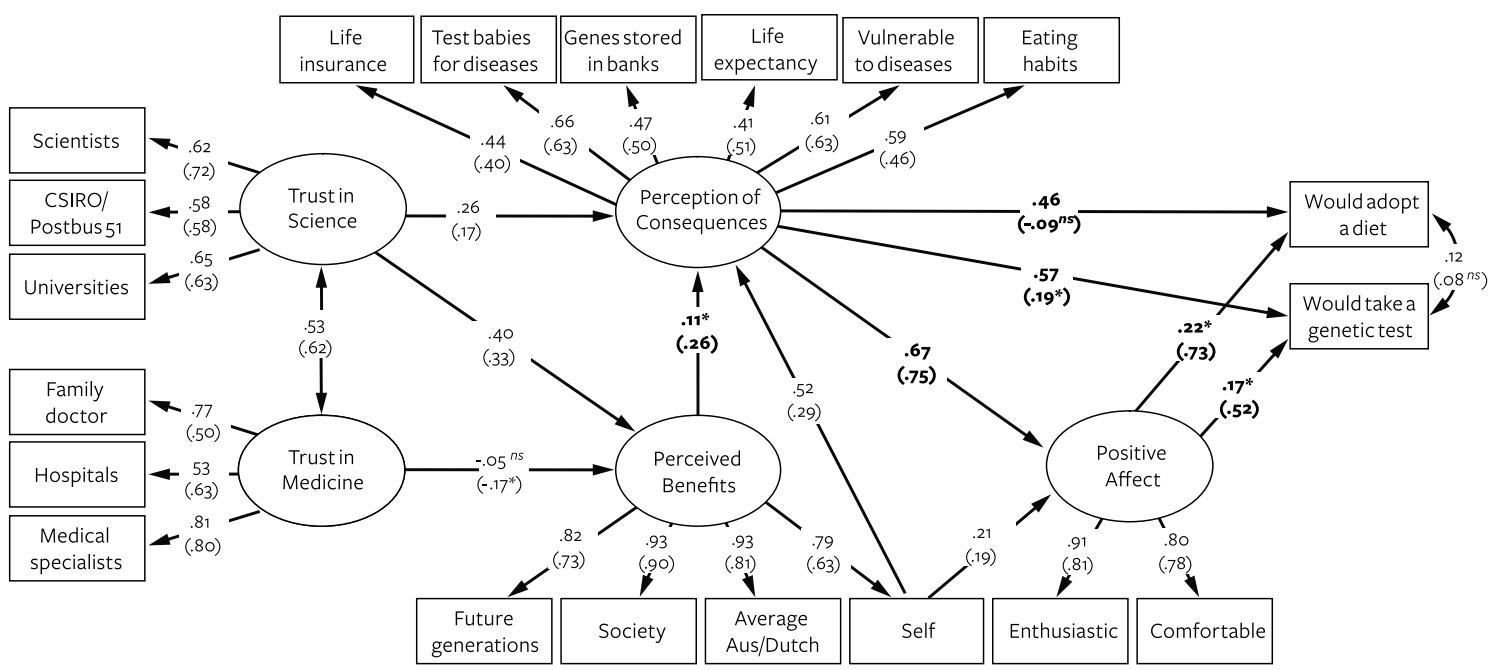

Note: Australian parameters are in parentheses. All SRWs were significant at $\mathrm{p}<.001$ unless otherwise stated.

* = significant at $\mathrm{p}<.01, \mathrm{~ns}=$ Not significant at .05 . All bolded estimates indicate significant differences between countries.

Figure 2 shows that the most proximal predictors of intention were positive affect and perceived consequences. Those who felt positively about personalized nutrition and viewed it as having positive consequences were more likely to report that they would take a genetic test and also adopt a diet suited to their genetic information. There was also a significant and strong indirect effect from desirable consequences via affect to both the diet (Dutch =.15, p<.oo1; Australian = $.55, \mathrm{p}<.001$ ) and genetic test items (Dutch $=.11, \mathrm{p}<.001$ : Australian $=.39, \mathrm{p}<. .001$ ). This suggests that perceived desirable consequences leads to a greater intention to take a genetic test and change one's diet because respondents felt good about personalized nutrition.

Interestingly and unexpectedly, the perceived costs/benefits item 'cost/benefit to the self' was a relatively proximal predictor of intention via its influence on positive affect and perceived consequences. For both countries, a belief that the person him or herself would benefit from 
personalized nutrition directly increased positive affect. Additionally, a belief that personalized nutrition would have desirable consequences for people in general led both to a stronger intention to adopt a diet and to take a genetic test (the indirect effect of self on diet was .36, $\mathrm{p}<.001$ for the Dutch and .27, $\mathrm{p}<.001$ for Australians; on test, Dutch was .39, $\mathrm{p}<.001$ and .27, $\mathrm{p}<.001$ for Australians). The influence of perceived benefits for other people (i.e., apart from the self) on intention was relatively minor for both countries. If personalized nutrition was perceived to be beneficial to people in general, there was a tendency, particularly for Australian respondents, to perceive the consequences as being more desirable, which then leads to increased positive affect and then to a stronger intention to take a test and adopt a diet.

Figure 2 also suggests that trust in science, but not trust in medicine, was the most important predictor of beliefs in the consequences and benefits of personalized nutrition. The indirect effect of trust in science was significant for both countries on both intention to adopt a diet (Dutch: $.30, \mathrm{p}<.001$; Australian: .17, $\mathrm{p}<.001$ ) and to take a genetic test (Dutch: .33, $\mathrm{p}<.001$; Australian: .20, $\mathrm{p}<.001)$. Thus, if respondents trusted science, they were more likely to take a test and adopt a diet because they believed that personalized nutrition would lead to desirable consequences and more benefits that would lead them to feel more positive.

As expected, affect played a greater role in predicting both intentions for the Australians, but desirable consequences were more important for the Dutch. The direct effect of affect on both intentions was significantly stronger in the Australian sample than in the Dutch sample, and the direct effect of desirable consequences on intentions was significantly stronger for the Dutch sample. For the Australian sample, intention to change one's diet and take a genetic test was more likely to be based on an emotional reaction toward personalized nutrition. Although the Dutch also based their intentions on affect, their intention to take a test or change their diet was much more likely to be based on their beliefs about the possible consequences that personal nutrition has for society. If the personal consequence variable could be defined as a cognitive variable and positive affect as a more automatically generated emotive response, then this pattern of findings might indicate that before deciding to take a genetic test or changing their diet, Dutch individuals are more likely to consider the consequences of such actions, whereas the Australians are more likely to decide based on their feelings.

\subsection{Discussion}

The aim of this study was to investigate the influence of social trust, rational cognition and affective evaluations on the intention to adopt personalized nutrition. We also developed a model, tested its fit for the Dutch and Australian populations, and explored the differences between the two samples. There has been a history of extensive public debate and media attention on gene technology in The Netherlands, while there has been little debate in Australia, a comparable western country in terms of values and culture.

Based on prior studies of GM food, genetic testing and dieting, three socio-psychological factors that might influence the intention to adopt personalized nutrition were considered. The model 
that included these three factors was found to be a good fit for both populations. The structure of the way these three factors influence the intention to adopt personalized nutrition was the same for both the Dutch and Australian public. Trust predicted perceived benefits which, in turn, predicted the perception of consequences, leading to an emotional response and, finally, to an intention to adopt personalized nutrition. Thus, if respondents trusted science, they were more likely to take a test and adopt a diet because they believed that personalized nutrition would lead to desirable consequences and more benefits. If personalized nutrition was perceived to be beneficial to people, then there was a tendency, particularly for Australian respondents, to perceive the consequences as being more desirable, which then led to increased positive affect and a stronger intention to take a test and adopt a diet. Perceived desirable consequences led to a greater intention to take a genetic test and change one's diet because respondents felt good about personalized nutrition. Unexpectedly, we found that a belief that the self would benefit from personalized nutrition increased positive affect and increased the perception that it would have desirable consequences for people, which both led to a stronger intention to adopt a diet and take a genetic test. These results suggest that individualism or self-interest could play a role in this process. When introducing a new technology such as personalized nutrition into society, the personal benefits should be clear in order to obtain public acceptance and intention to adopt the new technology.

These findings highlight the important role of affective evaluations and provide support for the role of the affect heuristic in decision making (Slovic et al., 2007). Further, our results demonstrate the crucial role of trust as an indirect predictor, via a more rational cognitive process, as a determinant of the intention to adopt a new technology, thus supporting the findings of Siegrist's model (2000).

In the current study we operationalised rational cognition in two ways and found that the perception of consequences was a more important predictor for intention to adopt personalized nutrition than the cost benefit perceptions. An explanation for this result could be that the perceptionofconsequencesreflectsprojectedpossibleoutcomes, whereascost/benefitperception is a more general assessment of weighing up the pros and cons of a new technology. The concept of perception of consequences, as used in this study, can perhaps be seen as the result of more general beliefs, norms and values. The possible consequences of personalized nutrition, such as privacy issues and less control over sensitive information could directly challenge some of these embedded beliefs, such as freedom of choice, equality or autonomy. Bardi and Schwartz (2003) found substantial correlations between values and corresponding behaviors. Further research into the role of values and lifestyle in the process preceding the perception of consequences of a new technology could provide further insight on this phenomenon.

The process of forming intentions was found to be relatively similar in both national settings, but some differences were found. Australians based their intentions to adopt personalized nutrition more on emotion, and the Dutch relied more on rational decision-making. The direct effect of positive affect on both intentions was significantly stronger amongst the Australian sample than the Dutch sample, and the direct effect of desirable consequences on intentions was significantly stronger for the Dutch sample. For the Australian sample, intention to change one's diet and take a genetic test was more likely to be based on an emotional reaction toward personalized 
nutrition. Although the Dutch also based their intentions on affect, their intention to take a test or change their diet was much more likely to be based upon their beliefs about the possible consequences that personal nutrition has for society. This provides support for the idea that the provision of information leads to more rational decision making. Thus, in the Dutch situation the deficit model seems to hold, whereas in the Australian situation the trust model could better reflect the process of forming the intention to adopt personalized nutrition. Implications for these findings could be that, depending on the level of media attention or information provided on a new technology, support for the technology should be found in different ways.

Despite these findings, this study has some limitations that must be considered. First, the data were collected differently in the two countries, using telephone surveys in Australia and online surveys in The Netherlands. The difference between online and telephone surveys has been studied by several authors. Braunsberger, Wybenga, and Gates (2007) argue that online panel surveys can be used as viable alternatives to telephone surveys. We found factor loadings to be stable and consistent across methods and thus expect these differences in data collection to have limited influence on the results. Additionally, there are some minor differences in the measurement of the constructs, in wording and in scaling between the two surveys. However, the factor loadings showed a highly similar pattern and the use of latent variables overcomes many of the problems that arise at the item level. In the Australian survey, respondents had the opportunity to answer "don't know" to all questions, whereas the Dutch did not, which led to few missing values in the Australian data. However, because of the use of structural equation modeling, missing data does not negatively influence the quality of the model. Our decision to measure the perceived costs and benefits of personalized nutrition within one scale seemed appropriate. The overall evaluation of the relative costs and benefits yield a single indicator which provides a useful and efficient alternative for two scales that ask separately about costs and benefits.

One question that arises from the findings relates to the differences in emotions and rationality between the Australian and Dutch results. Our comparison between the two national groups showed that the Dutch seem to process information about nutrigenomics using the more central cognitive route, while the Australians rely on the more peripheral emotional route. This could be explained by the assumption that the Dutch have more information available on the topic, with national information services such as Postbus 51 or the Voedingscentrum (nutritional centre). But above all, people in The Netherlands, compared to Australia, have experienced significantly more media attention and public debate around genetic technologies. In The Netherlands and other European countries, the public was exposed to an extensive public debate about the introduction of GM between 1991 and 1996 (Gutteling, Midden, Smink \& Meijnders, 2001). Until today, introduction of GM food on the European market has been minimized as a result of this debate. In Australia, the introduction of genetic engineering and GM food was accompanied by less resistance and occurred with relative silence (Lockie, 2006). Thus, it could be argued that the Dutch have been exposed to more information and arguments relating to genetics than Australians. This could possiblylead to a difference in the process of forming an intention to adopt personalized nutrition. When forming an intention to adopt a new technology, the dual process theory identifies two routes for information processing and decision-making, the affective and cognitive routes (Slovic et al., 2005). More insight could be gained on this phenomenon through 
further research in different cultural settings on the role of dual processing in decision-making on the adoption of a new technology.

Another question to be addressed is whether the differences in emotions and rationality explain the differences in intention between Australia and The Netherlands. As shown in Appendix 1 the Australians had a significantly higher intention to take agenetic test than the Dutch (Australians: $\mathrm{M}=3.89, \mathrm{SE}=0.05$; Dutch: $\mathrm{M}=3.29, \mathrm{SE}=0.03, \mathrm{t}(1631,78)=11.54, \mathrm{p}<.01, \mathrm{r}=.27)$ and a significant higher intention to adopt a diet based on their genetic profile to prevent diseases (Australians: $\mathrm{M}=4.43, \mathrm{SE}=0.03$; Dutch: $\mathrm{M}=3.96, \mathrm{SE}=0.02, \mathrm{t}(1824.53)=12.95, \mathrm{p}<.01, \mathrm{r}=.27)$. Van den Berg, Manstead, van der Pligt, and Wigboldus (2006) found that an affective or cognitive focus leads to the formation of different attitudes and this may be the case here. Further research in experimental settings can test these assumptions.

When trying to model consumer acceptance of technology-based food innovations, different studies contribute to the knowledge of which factors are important. This study represents a first attempt to model the intention to adopt personalized nutrition, with three key factors of trust, cognitions and affect found to play a role in the socio-psychological process. Testing this model for both the Australian and Dutch populations showed that the relative importance of affective and cognitive factors in the decision making process differed across the two national settings. Overall, these findings suggest that general attitudes held by the population of a country, together with their value structure and lifestyle factors, may shape one's intentions to adopt personalized nutrition. Exploring these factors in more detail will increase our understanding of the public's intentions to adopt emerging technologies.

\section{Acknowledgments}

The authors gratefully acknowledge the financial support of the NWO (Netherlands Organization for Scientific Research) and the CSG (Centre for Society and Genomics). In this paper use is made of data of the LISS panel administered by CentERdata. The authors would also like to thank the staff at the Swinburne University CATI facility and CentERdata for their efforts in conducting these surveys, and all of the respondents who kindly gave their time to participate. 


\section{References}

Ajzen, I. (1991). The Theory of Planned Behavior. Organizational Behavior and Human Decision Processes, 50 (2), 179-211.

Ajzen, I. (2001). Nature and operation of attitudes. Annual Review Of Psychology, 52, 2758.

Australian Bureau of Statistics (2006). Census Community Profile Series - Basic Community Profile.

Afman, L., \& Muller, M. (2006). Nutrigenomics: From molecular nutrition to prevention of disease. Journal of the American Dietetic Association, 106(4), 569-576.

Alhakami A.S. \& Slovic, P. (1994). A psychological study of the inverse relationship between perceived risk and perceived benefit. Risk Analysis 14(6), 1085-1096.

Armitage, C. J., \& Conner, M. (2001). Efficacy of the theory of planned behaviour: A meta-analytic review. British Journal of Social Psychology, 40, 471-499.

Bardi, A., \& Schwartz, S. H. (2003). Values and Behavior: Strength and Structure of Relations. Personality and Social Psychology Bulletin, 29(10), 1207-1220.

Bentler,P.M.,\&Wu,E.J.C. (2006).EQSfor Windowsstructuralequationprogrammanual. Encino, CA: Multivariate Software.

Bredahl, L. (2001). Determinants of consumer attitudes and purchase intentions with regard to genetically modified foods-results of a crossnational survey. Journal of Consumer Policy, $24,23-41$.

Braunsberger, K., Wybenga, H., \& Gates, R. (2007). A comparison of reliability between telephone and web-based surveys. Journal of Business Research, 60(7), 758-764.

Bauer, M. W., \& Gutteling, J. (2006). Issues Salience and Media Framing over 30 Years. In G. Gaskell \& M. W. Bauer (Eds.), Genomics and Society - Legal, Ethical \& Social Dimensions (pp. 113-130). London: Earthscan.

Conner M, Sparks P. 1996. The theory of planned behaviour and health behaviours. In Predicting Health Behaviour: Research and Practice with Social Cognition Models, ed. MConner, P Norman, pp. 121-62. Buckingham, England: Open Univ. Press

Costa-Font, J., \& Mossialos, E. (2007). Are perceptions of 'risks' and 'benefits' of genetically modified food (in)dependent? Food Quality and Preference, 18(2), 173-182.

Critchley, C., \& Turney, L. (2004). Understanding Australians' Perceptions Of Controversial Scientific Research. Australian Journal of Emerging Technologies and Society, 2(2), 82-107.

Eagly AH, Chaiken S. 1993. The Psychology of Attitudes. Fort Worth, TX: Harcourt Brace

Eng, T. R. (2004). Population health technologies: Emerging innovations for the health of the public. American Journal of Preventive Medicine, 26(3), 237-242.

Finucane, M. L., \& Holup, J. L. (2005). Psychosocial and cultural factors affecting 
the perceived risk of genetically modified food: an overview of the literature. Social Science \& Medicine, 60(7), 1603-1612.

Frewer, L. (2004) The public and effective risk communication. Toxicology Letters, 149(1-3), 391-397.

Frewer, L., Howard, C., Hedderley, D., \& Shepherd, R. (1996). What determines trust in information about food-related risks? Underlying psychological constructs. Risk Analysis, 16(4), 473-486.

Frewer, L., Lassen, J., Kettlitz, B., Scholderer, J., Beekman, V., \& Berdal, K. G. (2004). Societal aspects of genetically modified foods. Food And Chemical Toxicology, 42 (7), 1181-1193.

Frewer, L. J., Scholderer, J., \& Bredahl, L. (2003) Communicating about the risks and benefits of genetically modified foods: The mediating role of trust. Risk Analysis, 23(6), 1117-1133.

Gaskell, G., Allum, N., Wagner, W., Kronberger, N., Torgersen, H., Hampel, J., et al. (2004). GM foods and the misperception of risk perception. Risk Analysis, 24(1), 185-194.

Gaskell, G., Einsiedel, E., Priest, S., Ten Eyck, T., Allum, N., Torgerson, H., (2001). Troubled waters: the Atlantic divide on biotechnology policy. In G. Gaskell \& M. Bauer (Eds.), Biotechnology 1996-2000: The Years of Controversy (pp.53-79). London: NMSI Trading Ltd, Science Museum.

Gutteling, J. M., Midden, C., Smink, C., Meijnders, A., (2001). The Netherlands: controversy or consensus? In G. Gaskell \& M. Bauer (Eds.), Biotechnology 1996-2000: The Years of Controversy (pp. 229-236). London: NMSI Trading Ltd, Science Museum.

Inglehart, R., Basanez, M., Deiz-Medrano, J., Halman, L., \& Luijkx, R. (2004). Human Beliefs and Values: A Cross-Cultural Sourcebook based on the 1999-2002 values Surveys. Mexico City: Siglo XXI.

Lewis, R. D. (2003). The Cultural Imperative: Global Trends in the 21st Century. Maine: Intercultural Press, Inc.

Little, R.J.A. (1988). A test of missing completely at random for multivariate data with missing values. Journal of the American Statistical Association, 83, 1198-1202.

Lockie, S. (2006). Capturing the sustainability agenda: Organic foods and media discourses on food scares, environment, genetic engineering, and health. Agriculture and Human Values, 23(3), 313-323.

Meijboom, F. L. B., Verweij, M. F., \& Brom, F. W. A. (2003). You eat what you are: Moral dimensions of diets tailored to one's genes. Journal Of Agricultural \& Environmental Ethics, 16(6), 557-568.

Petty, R.E., \& Cacioppo, J.T. (1984). Source factors and the elaboration likelihood model of persuasion. Advances in Consumer Research, 11, 668-672.

Pin, R.R. \& Gutteling J.M. The Development of Public Perception Research in the Genomics Field - An Empirical Analysis of the Literature in the Field. Science Communication. Prepublished December 29, 2008; DOI: 10.1177/1075547008327273

Poortinga, W., \& Pidgeon, N. F. (2005). Trust in risk regulation: Cause or consequence of the acceptability of GM food? Risk Analysis, 25(1), 199-209.

Ronteltap, A., van Trijp, J. C. M., \& Renes, R. J. (2007). Expert views on critical success and failure factors for nutrigenomics. Trends in Food Science and Technology, 18(4), 189-200.

Ronteltap, A.,van Trijp, J.C.M., Renes, R.J., \&Frewer, L.J. (2007). Consumeracceptance of technology-based food innovations: Lessons for the future of nutrigenomics. Appetite, 49(1), 1-17.

Ronteltap, A., van Trijp J. C. M., \& Renes, R. J. Consumer acceptance of nutrigenomics- 
based personalised nutrition. British Journal of Nutrition, Published online by Cambridge University Press 15 May 2008 doi:10.1017/Sooo7114508992552

Siegrist, M. (2000) The influence of trust and perceptions of risks and benefits on the acceptance of gene technology. Risk Analysis, 20(2), 195-203.

Siegrist, M., Cvetkovich, G., \& Roth, C. (2000). Salient value similarity, social trust, and risk/benefit perception. Risk Analysis, 20(3), 353-362.

Sjöberg, L. (2001). Limits of knowledge and the limited importance of trust. Risk Analysis, 21(1), 189-198.

Slovic, P. (1999). Trust, emotion, sex, politics, and science: Surveying the riskassessment battlefield (Reprinted from Environment, ethics, and behavior, pg 277-313, 1997). Risk Analysis, 19 (4), 689-701.

Slovic, P., Peters, E., Finucane, M. L., \& MacGregor, D. G. (2005). Affect, risk, and decision making. Health Psychology, 24(4), S35-S4O.

Slovic, P., Finucane, M. L., Peters, E., \& MacGregor, D. G. (2007). The affect heuristic. European Journal of Operational Research, 177(3), 1333-1352.

Statistics Netherlands (2007). Statistical Yearbook 2007. Voorburg/Heerlen, The Netherlands: CBS.

Sturgis, P., \& Allum, N. (2004). Science in society: re-evaluating the deficit model of public attitudes. Public Understanding Of Science, 13(1), 55-74.

Sutton S. 1998. Predicting and explaining intentions and behavior: How well are we doing? J. Appl. Soc. Psychol. 28,1317-38

Tanaka, Y. (2004). Major psychological factors affecting acceptance of generecombination technology. Risk Analysis, 24(6), 1575-1583.

Townsend, E. (2006). Affective influences on risk perceptions of, and attitudes toward, genetically modified food. Journal of Risk Research, 9(2), 125-139.

Van den Berg, H., Manstead, A. S. R., van der Pligt, J., \& Wigboldus, D. H. J. (2006). The impact of affective and cognitive focus on attitude formation. Journal of Experimental Social Psychology, 42(3), 373-379.

Van der Pligt, J., \& de Vries, N. K. (1998). Belief importance in expectancy-value models of attitudes. Journal of Applied Social Psychology, 28(15), 1339-1354.

Verdurme, A., \& Viaene, J. (2003). Consumer beliefs and attitude towards genetically modified food: basis for segmentation and implications for communication. Agribusiness, 19(1), 91-113.

Zajonc, R. B. (1980). Feeling and Thinking - Preferences Need No Inferences. American Psychologist, 35(2), 151-175. 


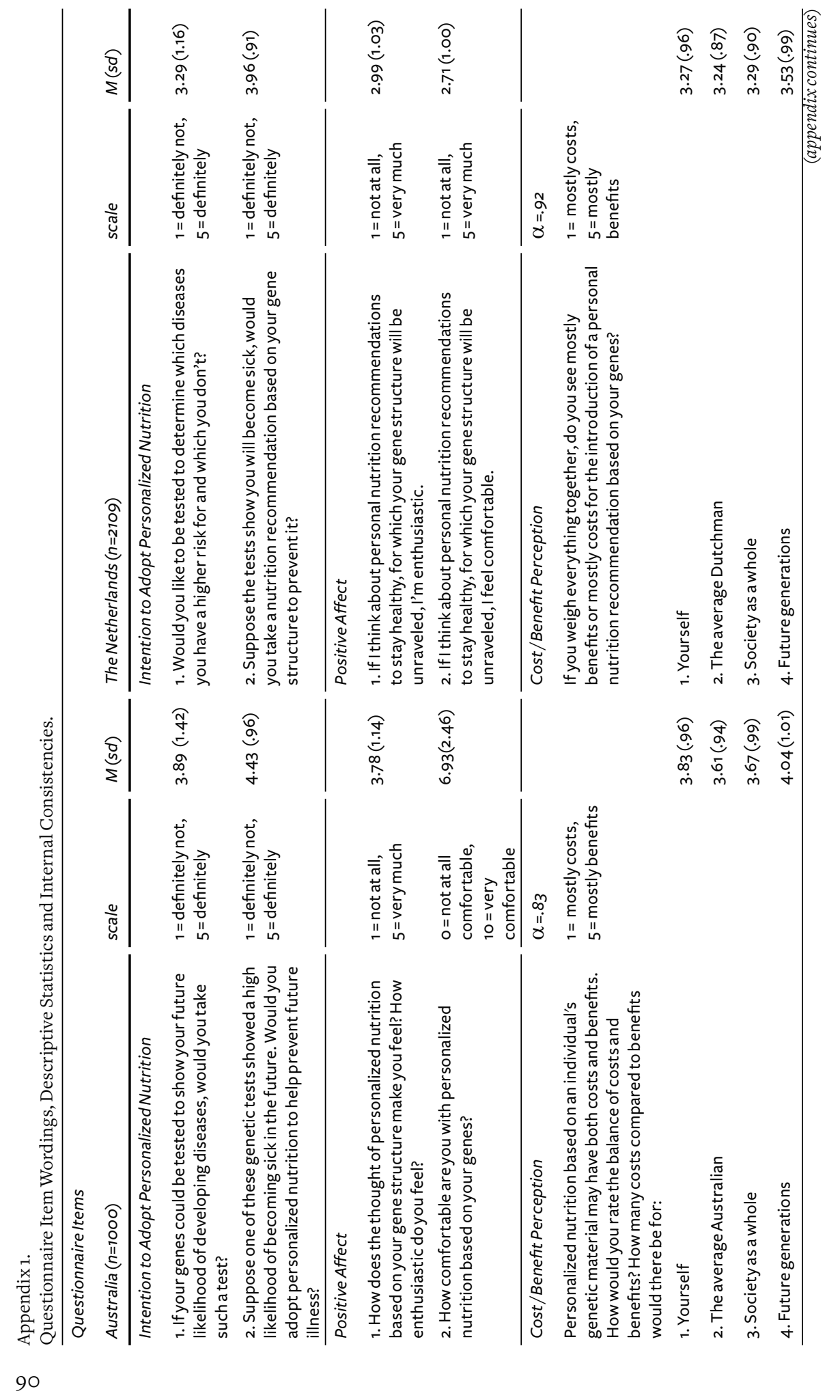




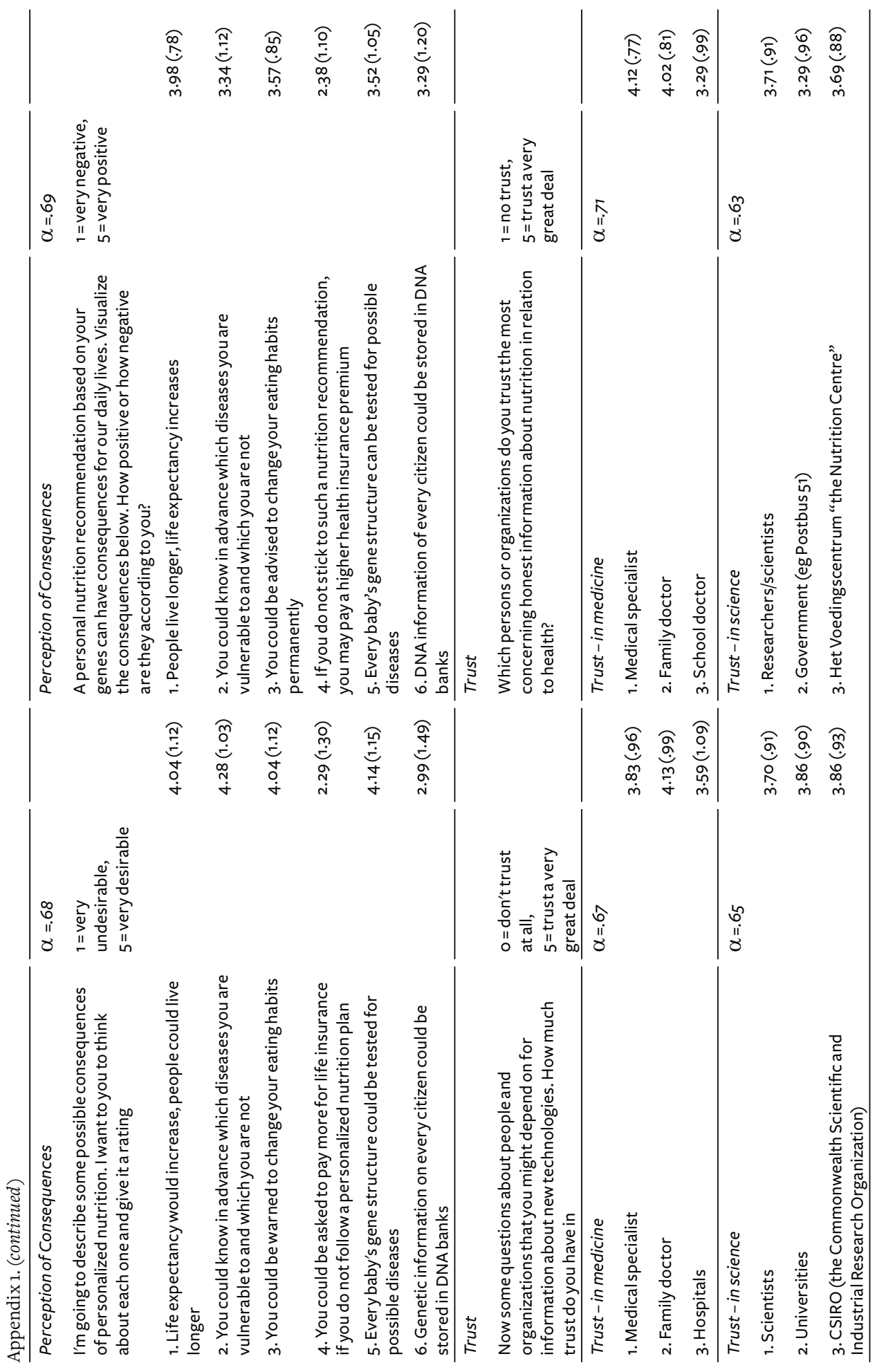




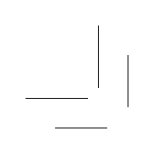

1 


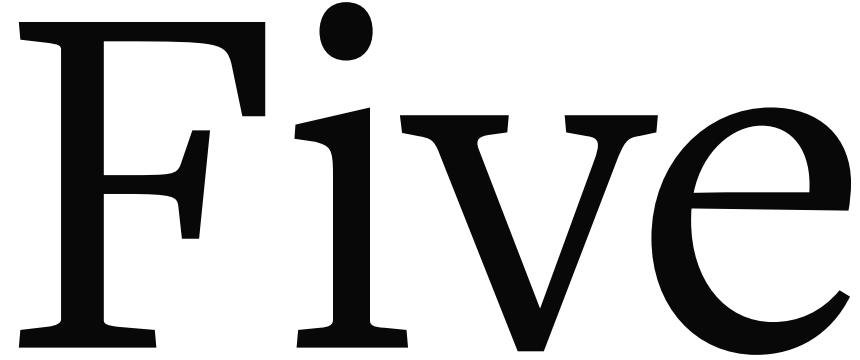

Intentions to Adopt

Nutrigenomics -

Personalized Nutrition

and Functional Foods

Renske R. Pin

Lynn J. Frewer

Erwin R. Seydel

Submitted 


\section{Abstract}

Predicting peoples' intentions about adoption of new technologies is an important element determining their successful development and implementation. The research presented here develops and tests a psychological model which predicts an individual's intention to prevent disease by adopting personalized nutrition based on their own genetic profile. Based on the existing literature, various factors that might influence the adoption of nutrigenomics have been identified. The predictive capacity of these various psychological factors on the intention to adopt personalized nutrition is tested: factors include positive and negative affect, cost and benefit perceptions, attitude, and involvement in nutrigenomics. The model, tested using data collected from a representative sample in the Netherlands $(n=2170)$, showed a good fit. The results show that the higher an individual's involvement in personalized nutrition, the more positive they are about its application and the more strongly they intend to adopt it. The model was replicated and validated six months later $(n=1636$, original sample). The utility of the model to another area of food technology was also tested and validated $(\mathrm{n}=2084$, new sample), suggesting generic applicability at least in the food technology domain.

Keywords:

perception, nutrigenomics, personalized nutrition, functional foods, multi group structural equation modeling 


\title{
Five
}

Intentions to Adopt Nutrigenomics - Personalized

\author{
Nutrition and Functional Foods
}

\subsection{Introduction}

Predicting peoples' intentions to adopt new technologies and their applications is important for technological development and successful implementation (see for example, Flynn \& Bellaby, 2007). However, the relationship between technological innovation and societal responses has a long and complex history. Research has identified considerable variation in societal responses according to the area of technological application. In particular, societal responses to the application of different technologies in the agrifood sector has been a particular focus of societal concern, compared to, for example, medical applications of the same technology. As case in point is that of genetic modification applied in different domains towards the end of the last century (Bredahl, 2001; Frewer et al, 2004). The question arises as to whether individuals' reactions to technologies applied in the agrifood sector are more favorable if they are associated with tangible and personally applicable health benefits? (Schenk et al, 2008). The area of nutrigenomics is of interest here. On one hand, the application of nutrigenomics may be controversial, but the potential health benefits to individual consumers may receive a favorable societal response, because consumers perceive the application to be more closely linked to medicine than to food.

This paper examines intentions regarding the adoption of nutrigenomics-or, more specifically, the application of personalized nutrition-and considers the role of potentially influential psychological determinants in influencing a person's decision to adopt personalized nutrition. The aim of this study is to develop and test a theoretical model predicting individuals' intentions in this regard, including their perceived cost-benefit ratio, positive and negative affect associated with personalized nutrition, their attitudes towards, and their involvement with, personalized nutrition. The temporal stability of the resultant model is tested, and its utility in another food technology application domain, functional foods, assessed.

Research in the area of nutrigenomics has focused on the relationship between human nutrition and human genetics. An important goal is to maintain and promote health and prevent disease (Afman \& Muller, 2006). A potentially important area of application is that of "personalized nutrition", defined as "dietary advice tailored to individual needs to help consumers select foods that are optimally aligned with their genetic makeup so as to promote health and wellness". Nutrigenomics has the potential to deliver important public health benefits, but may also have some disadvantages. For example, the application of genomics technologies may raise ethical concerns about how they could compromise the integrity of nature (Frewer et al, 1997). Application of human genetics raises issues of privacy and control over sensitive information (Castle \& Ries, 2007; Clayton, 2003; Ronteltap, van Trijp, Renes, \& Frewer, 2007; Slamet- 
Loedin \& Jenie, 2007).

Previous research has looked at a range of factors that influence public perceptions of food innovations (e.g., Ronteltap, van Trijp, Renes \& Frewer, 2007; Frewer et al, 2003). Several of these studies have attempted to combine various psychological determinants into factors into a predictive model of behavioral intention (Frewer et al, 2003; Pin \& Gutteling, 2008). However, few published analyses have comprehensively examined intentions about the adoption of personalized nutrition.

Literature on public perceptions of genomics (Pin \& Gutteling, 2008) focuses on predictors such as perceptions of cost and benefit, positive and negative affect associated with a specific technology, and attitudes towards that technology. Pin, Critchley, and Hardie (submitted) have developed a model predicting personalized nutrition, and tested the model in two different national settings. They found differences in the balance between emotion and rationality in Australian and Dutch results. The Dutch participants in the study tended to process information about nutrigenomics by increased reliance on rational processing (Elaborative processing), while the Australians relied on a more emotional and peripheral information processing route (heuristic processing) (Petty \& Cacioppo, 1986). Furthermore, it was reported that, if an individual perceived a benefit from personalized nutrition, this increased positive affect and the belief that the technique would have desirable consequences. Both of these, in turn, strengthened an individual's conviction about whether or not to adopt personalized nutrition. Based on these findings, the aims of the research presented here are to consider the role of the self and personal involvement in personalized nutrition in an individual's intention to adopt it, and to consider the role of information processing and the affect heuristic in determining the cognitive and affective routes determining behavioural intention. A theoretical model was developed, which was designed to assess the influence of involvement, cost and benefit perceptions, positive and negative affect, and attitude, on intentions about the adoption of personalized nutrition.

\subsubsection{The Intention to Adopt Nutrigenomics}

The field of personalized nutrition is still in its infancy. Scholars in the nutrition field differ considerably in their optimism about the extent to which personalized nutrition will improve human health. It is currently unclear how applications of nutrigenomics such as personalized nutrition will evolve (Ronteltap, Van Trijp \& Renes, 2008). Despite high levels of uncertainty about the development and success of personalized nutrition in the near future, some genetic scientists believe that it has potential to improve public health (Afman \& Muller, 2006). The public has the power to influence the process of commercialization through acceptance of its commercial applications (Ronteltap, van Trijp \& Renes, 2007).

As little is known about intentions regarding the adoption of personalized nutrition, the public's reactions to the possibility of a personalized diet are of interest, because many individuals do not yet have crystallized or strongly held attitudes about this phenomenon. 
5.1.2 Involvement and the Affect Heuristic and Their Influence on the Intention to Adopt

\section{Involvement}

Researchersin the field of persuasion studyinvolvement as a predictor of behavioral intention, and they consider involvement to be an important factor that influences whether information about a topic results in persuasion, or attitude change (Park, Levine, Westerman, Orfgen, \& Foregger, 2007). Involvement may be defined as "the motivational state induced by an association between an activated attitude and some aspect of the self-concept" (Johnson \& Eagly, 1989). Petty and Cacioppo (1986) use the term "issue involvement" or "personal relevance" to refer to the extent to which a topic has personal meaning and important consequences for an individual. From their meta-analysis, Johnson and Eagly (1989) concluded that participants with high outcomerelevant involvement (their ability to attain desirable outcomes) were more persuaded by strong arguments about a particular issue than were low-involvement subjects. Johnson (1994) found that prior information about a persuasive issue interacts with outcome-relevant involvement to influence attitude change.

Dual-process models such as the Elaboration Likelihood Model (ELM) (Petty \& Cacioppo, 1986), assume that there are two routes to persuasion: these are the central/systematic compared to the peripheral/heuristic routes. An individual is motivated to process information about issues of high personal relevance centrally.

Darke and Chaiken (2005) report that perceived personal relevance has a pronounced directional impact on attitude judgment, cognitive processing, and persuasive impact of information. They based their studies on the heuristic-systematic model (Eagly \& Chaiken, 1993), which specifies that attitude judgment may reflect multiple goals or an individual's preferences for outcomes following information provision. The model's distinction between accuracy goals (that is, the desire to make objectively valid judgments) and defense goals (that is, the desire to hold and maintain attitudes that have positive implications for the self) is central to the question of how self-interest affects attitudes. In their analysis, they considered self-interest to be primarily a source of defensive motivation, which should generally act so as to bring individuals' attitudes in line with self-interests. Thus, self-interest should act on information processing to produce negative attitudes when issues presented in incoming information are primarily associated with substantial costs and few benefits, but result in positive attitudes when issues are primarily associated with benefits. In one study, Darke and Chaiken focused on the role of perception of cost and benefits and found that personal relevance affected attitudes; this effect was partly mediated by the way in which perceived personal relevance affected participants' perceptions of personal costs and benefits.

Based on the theoretical predictions of the dual-process model, and the findings summarized above, involvement should predict both positive and negative affect and cost and benefit perceptions. The more involved an individual is with personalized nutrition, the stronger the positive and negative affect will be. Furthermore, the individual will perceive more cost, and more benefits. As such, higher involvement could lead to feelings that are more positive and higher perceived benefits, but also could lead to more negative feelings and higher perceived costs. 
Positive and Negative Affect and The Affect Heuristic

Slovic, Finucane, Peters, and MacGregor (2007) introduced a theoretical framework that describes the importance of affect in guiding judgments and decisions through reliance on affective (emotional) responses as the affect heuristic.

Positive affect reflects the extent to which a person feels enthusiastic, active, and alert. Negative affect is a general dimension of subjective distress that subsumes a variety of aversive mood states, including anger, contempt, disgust, guilt, fear, and nervousness (Watson, Clark, \& Tellegen, 1988). Although the terms positive affect and negative affect suggest that these two mood factors are polar opposites (and as such, would be strongly negatively correlated), they have, in fact, emerged as highly distinctive dimensions that can be meaningfully represented as orthogonal dimensions in factor analytic studies of affect (Watson, Clark, \& Tellegen, 1988).

There is evidence to suggest that evaluations of an event or attitude object stored in memory may become active when the individual encounters the same event or attitude object (Bargh, Chaiken, Govender, \& Pratto, 1992). The question is whether an "automatic attitude activation effect" will cause people to link nutrigenomics to controversial technologies such as genetically modified food. Ferguson, Bargh, and Nayak (2005) report that an individual's automatic evaluation can influence deliberative judgments about subsequent stimuli. It is possible that, in the case of a new technology, where not much information is available, people tend to rely on affect more than the analysis of costs and benefits. When individuals evaluate developments related to the new technology negatively, this negative affect will influence their attitudes and intentions about the technology under consideration. Dijksterhuis and Van Knippenberg (1998) called this relation, in which perception has a direct and pervasive impact on overt behavior in an experimental setting, the "affective response".

It is hypothesized that positive and negative affect will predict attitude towards personalized nutrition, as well as have a direct effect on behavioral intentions about applications of the new technology. The more positive the individual feels about personalized nutrition, the more positive their attitude will be and the more likely it will be that they intend to adopt the practice. The more negative the person feels about personalized nutrition, the more negative their attitude will be and the less likely it will be for them to adopt the technology.

\subsubsection{Cost and Benefit Perception and Reactions to Other Technologies}

The perception of costs and benefits is an important determinant of reactions to new technologies (Gaskell et al, 2004; Ronteltap, van Trijp, Renes, \& Frewer, 2007).There is also evidence to suggest that perceptions of risk and benefit are inversely correlated: that is, as benefit perceptions increase, perceptions of risk decrease, and vice versa (Alhakami and Slovic, 1994; Frewer et al., 2004).

When considering cost and benefit measurement, many studies have focused on either the cost or the risk perception associated with a new technology (e.g., Slovic et al., 2005). Few studies have considered both the cost perception and the benefit perception (e.g., Poortinga \& Pidgeon, 
2005). Alhakami and Slovic (1994) were among the first to explore the generally robust, inverse relationship between the perceived risks and benefits of various technologies. Risks and benefits can be seen as two separate concepts, where technology can have both costs and benefits that can be considered separately.

When looking at the relationship of cost and benefit perception with other determinants, Siegrist (2000) found that perceived benefit and perceived risk determine the acceptance of biotechnology. Poortinga and Pidgeon (2005) have studied the cost and benefit perception of the acceptance of genetically modified (GM) food and found that affect accounts for a large portion of the variance between perceived risk, perceived benefit, trust in risk regulation, and the acceptability of GM food. However, Frewer et al (2003) report that perceive risk is more important than perceived benefit in predicting behavioural intention to purchase genetically modified food.

Pin, Critchley, and Hardie (submitted) found that if personalized nutrition was perceived to benefit to individuals, then people (especially the Australian participants) had a tendency to perceive the consequences as being more desirable, a perception that then improved affect and strengthened intentions about taking a test and adopting a diet.

It is expected in the present study, that cost and benefit perceived by different individuals about personalized nutrition will predict negative and positive affective evaluations of the technology, respectively. The more benefits a person perceives to be potentially derived from personalized nutrition, the more positive they will feel about the associated technology. The more costs a person perceives as resulting from personalized nutrition, the more negative they will feel about the technology.

\subsubsection{Attitude}

The attitude construct is a major focus of theory and research in the social and behavioral sciences (Ajzen, 2001). Attitude represents a summary evaluation of a psychological object captured along such dimensions as good-bad, harmful-beneficial, pleasant-unpleasant, and likable-dislikeable. It is assumed that evaluative judgments are the result of cognitive processes: associations between the attitude object and valued attributes. However, Ajzen concludes that some theorists have challenged this assumption, proposing that evaluations may also be controlled by affective processes. In fact, the affective primacy hypothesis (Zajonc, 1980) assigns precedence to affect over cognition. An alternative, position is based on the multi-component view of attitude and assumes that cognition, as well as affect, influences evaluations (Eagly \& Chaiken, 1993). Furthermore, the ability of attitudes to predict behavioral intentions is a major focus of theory and research, and researchers generally recognize that attitudes are relevant to understanding and predicting social behavior (Ajzen, 2001). Therefore, it is expected that attitude can be predicted by positive and negative affect and that it will determine the intention to adopt personalized nutrition. 


\subsubsection{A Model Predicting Intention to Adopt Nutrigenomics}

Based on the available literature, it is here hypothesized that an individual's intention to adopt personalized nutrition is significantly influenced by their personal involvement, the perceived costs relative to perceived benefits, positive and negative affect, and attitude. A model has been developed in order to predict intentions regarding the adoption of personalized nutrition based on these factors. First, personal involvement leads to adoption of either heuristic or elaborative processing. The more involved an individual is in the issue of personalized nutrition, the stronger their views will be. The more beneficial an individual thinks the technology will be for them personally, the more positive affect will result from the technology. The more positive they feel about the technology, the more positive will be their attitude The greater the costs the individual thinks the technology will incur, the more negative they will feel about the technology and the more negative will be their attitude. Their attitude, in turn, will predict their intentions regarding adoption of the technology. Figure 1 depicts the model.

Figure 1.

Theoretical model of the intention to adopt nutrigenomics

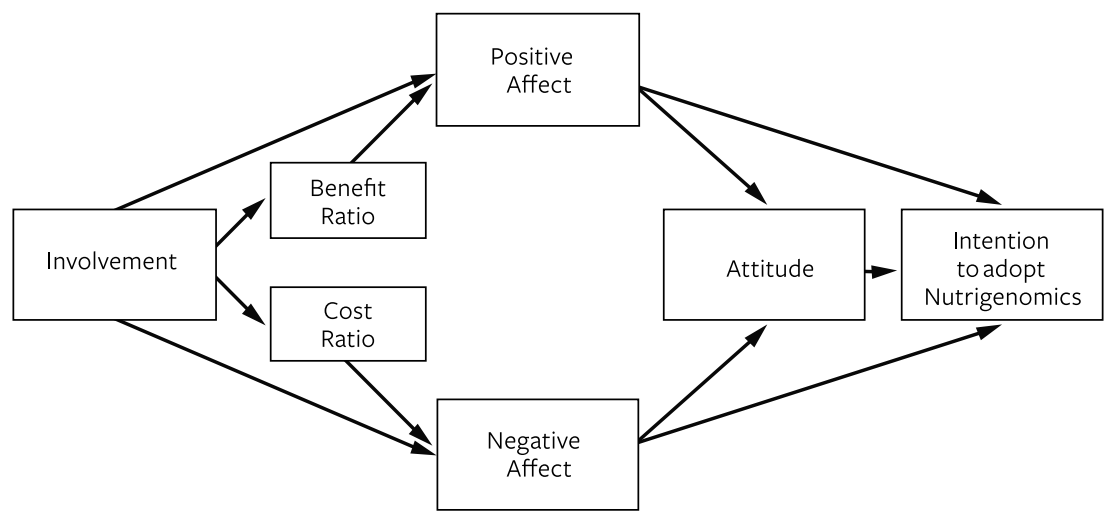

\subsubsection{The Aim and Design of the Present Study}

The aim of this study is to develop and test a model to predict intentions regarding personalized nutrition, including the determinants thought to influence the adoption process: specifically, cost and benefit ratio, positive and negative affect, attitude, and involvement.

To test the temporal stability of the proposed model (Boomsa 2000, Schumacker \& Lomax, p. 261p.314), the model constructs were measured at two points in time, with a six months interlude. Personalized nutrition is very new and still largely unknown by the public. A comparable but more established technology is functional foods (foods that are part of a normal diet and have been fortified or enriched to provide additional health-promoting benefits in conjunction 
with normal nutritive properties) (Diplock et al., 1999; Hasler, 2002). Functional foods can be conceptualized as having two primary effects on health: the enhancement of physiological function and the reduction of disease risk (Verschuren, 2002; Devcich, Pedersen \& Petrie, 2007). Both personalized nutrition and functional foods represent applications of technologies in the nutrition field and are aimed to improve health and prevent disease. Functional foods represent a more commercially implemented development, promoting new, more beneficial food products associated with health claims and higher prices. Functional foods per se do not have such great potential for negative social impact, for example in terms of privacy.

Specifically, the purposes of the study were fourfold: (a) to identify factors contributing to the intention to adopt personalized nutrition, (b) to determine the pattern of causal structure, (c) to test the stability of the model by validating this structure across a second wave sample six months later, and (d) to generalize conclusions about other new food technologies by validating this structure across an independent sample for functional foods.

\subsection{Method}

\subsubsection{Data Collection and Samples}

The data were collected in October 2007 (Wave 1) via an online panel. A random sample of 4254 Dutch individuals aged 16 and older was drawn, individuals being were presented with the survey questions as part of a monthly questionnaire.

The sample was largely representative of the Dutch population, matching the proportions of the Statistical Yearbook 2007 (Statistics Netherlands, 2007). The percentage of female participants was significantly higher than the percentage of male participants ( $54 \%$ and $46 \%$, respectively; $\chi^{2}(1)=29.0, p<.01$ ). Participants ranged in age from 16 to 107 years, with a mean of 45 years $(S D=15.5)$. A total of $28 \%$ of participants had a high level of formal education (i.e., HBO or WO), 34\% an intermediate level (i.e., MBO, HAVO or VWO), and 32\% a lower level (i.e., eighth grade or less, $\mathrm{VMBO}$ ). Only $1.7 \%$ said they had undergone a genetic test. The participants were randomly assigned to either the personalized nutrition condition $(n=2170)$ or the functional foods condition $(\mathrm{n}=2084)$. Of the 2170 participants, $26.2 \%$ said they had previously heard of personalized nutrition based on one's gene structure; of the 2084 participants, $62.5 \%$ said they had previously heard of functional foods.

Then, the panel members who were in the personalized nutrition group were asked to participate in the second survey in April 2008 (Wave 2), six months later. Of the 2170, 1636 participants completed the questionnaire again. No significant differences were found for gender or educational level. As expected, the participants were on average a little bit older in April 2008 ( $M$ $=46.29, \mathrm{SE}=0.39)$ than in November $2007(M=44.85, S E=0.39, t(3803)=-2.82, p<.01, r=.05)$. 


\subsubsection{Materials}

The personalized nutrition questionnaire began with the following information: "Scientists say that in a few years they will be able to tell what diseases you are vulnerable to, based on your genetic profile. It may be possible to prevent disease and improve your quality of life by eating the foods that best fit your gene structure." The questionnaire then asked participants whether they had heard of personalized nutrition and whether they had ever had their genetic material tested.

The introduction to the functional food questionnaire stated: "A new development is functional foods, foods with something added to help you stay healthy and in shape. These products are claimed to improve resistance to disease, lowering blood pressure or cholesterol. These products are possibly a solution for our unhealthy eating habits." The questionnaire then asked participants whether they had heard of functional foods before and whether they had ever had a genetic test. Appendix 1 gives all questionnaire item wording, descriptive statistics, and internal consistencies.

\section{Intention to Adopt Personalized Nutrition and Functional Foods}

The intention to adopt the applications of the new technologies was assessed with four items for each condition (see Appendix 1). The personalized nutrition version included four items, asking each participant to indicate whether they intended to take a genetic test in order to obtain personalized dietary advice and then adopt the personalized diet. The functional foods version included four items, asking whether each individual intended to buy and eat functional foods. All were measured on a five-point scale (definitely not - definitely, personalized nutrition $\alpha=.81$; functional foods $\alpha=.80$ ).

\section{Attitude}

Each participant's attitude towards the applications of the new technology was measured by asking what they thought in general about the technology, as rated on the following fivepoint scales: bad-good, negative-positive, adverse-advantageous, wrong-right, foolish-wise (personalized nutrition $\alpha=.95$; functional foods $\alpha=.94$ ).

\section{Positive and Negative Affective Evaluation}

Positive affective evaluation was measured with three statements about feelings of enthusiasm, happiness or optimism, and comfort. Each question was on a five-point scale (not at all - very much, personalized nutrition $\alpha=.90$; functional foods $\alpha=.88$ ). Negative affective evaluation was measured with three statements about feelings of worry and uneasiness or restlessness as well as to an indefinable feeling. Allwere measured on a 5-point scale (not at all-very much, personalized nutrition $\alpha=.81$; functional foods $\alpha=.80$ ).

\section{Cost and Benefit Perception}

To measure the perception of costs and benefits, participants were asked to rate the costs and benefits of the technologies. The questions were based on the risk and benefit scale proposed by Poortinga and Pidgeon (2005) and asked how many costs and benefits there would be for the average Dutch citizen, for society as a whole, and for future generations. All four answers 
were measured on a five-point scale (very few costs - many costs, personalized nutrition $\alpha=$ .84 ; functional foods $\alpha=.87$; very few benefits - many benefits, personalized nutrition $\alpha=.89$; functional foods $\alpha=.90$ ).

\section{Involvement}

Involvement with the new technology was assessed with four statements about appeal, importance, involvement, and personal interest. All four were on a five-point scale (strongly disagree - strongly agree, personalized nutrition $\alpha=.91$; functional foods $\alpha=.90$ ).

\subsubsection{Data Analysis}

Structural equation modeling procedures based on the analysis of covariance structures were used to identify potentially important theoretical relationships, and to test the plausibility of a postulated causal system comprising the latent variables of attitude, positive and negative affect, cost and benefit perceptions, and involvement. This method uses a confirmatory approach to data analysis and, as such, requires an a priori postulation of model structure substantiated by theory or empirical research. Analyses were performed using the Statistical Package for the Social Sciences (SPSS) version 16 and Amos version 7 with maximum likelihood estimation; they were conducted in five stages.

First, preliminary analyses identified cases with multivariate outlying scores in each of samples (Personalized Nutrition wave 1, $\mathrm{n}=140$; wave 2, $\mathrm{n}=108$; Functional Foods, $\mathrm{n}=124$ ). Deleting these cases resulted in sample sizes of 2030, 1528, and 1960, for Personalized Nutrition wave 1, wave 2, and Functional Foods, respectively. Prior to the analyses, data were checked for normality. Because of skew to the lower end of the distribution of the measures Intention to Adopt and Attitude, a square-root (reciprocal) transformation was performed in order to correct skew (Garson, 2006). Second, items were combined to form multiple measurement indicators for each construct. In lieu of sequential combination, items were carefully grouped according to content in order to equalize the measurement weighting across indicators. In total, 27 indicators were used to measure the hypothesized structural model. Once the measurement model was established, the observed data were fitted to the hypothesized model and subsequently assessed for goodness-of-fit. Given evidence of inadequate fit, the model was re-specified to include additional causal paths identified by the post hoc modification indices as those that would contribute most to a significantly better-fitting model. Fourth, the final model was validated by testing for the invariance of all causal paths across the second wave sample using multi-group structural equation modeling. The final model was validated a second time by testing for the invariance of all causal paths across the independent functional foods sample.

As suggested by Holbert and Stephenson (2002), the assessment of model fit was based on multiple criteria that reflected statistical, theoretical, and practical considerations. These were (a) The chi-square estimate with degrees of freedom, given that it is still the most commonly used way to compare models (Hoyle \& Panter, 1995); (b) the standardized root mean squared residual (SRMR), as a second absolute fit statistic (Hu \& Bentler, 1999); in combination with (c) the Tucker-Lewis index (TLI) as incremental index; (d) the root mean squared error of 
approximation (RMSEA; Browne \& Cudeck, 1993); and (e) the substantive meaningfulness of the model (see MacCallum, 1986). Hu and Bentler (1999) recommend using a cutoff value close to .95 for TLI in combination with a cutoff value close to .09 for SRMR to evaluate model fit, with the RMSEA close to .06 or less.

\section{$5 \cdot 3 \cdot$ Results}

To test the temporal stability of the model at two points in time, the extent to which the public intends to adopt personalized nutrition in comparison to their willingness to adopt functional foods, construct means and standard deviations were examined first. On average, the 1636 participants included in both waves intended to adopt personalized nutrition significantly more in November $2007(M=3.70, S E=0.02)$ than in April $2008(M=3.42, S E=0.02, t(14.21), p<.01)(a$ medium-sized effect $r=.33$ ). On average, participants intended to adopt personalized nutrition significantly more $(M=3.70, S E=0.02)$ than they did functional foods $(M=2.90, S E=0.02$, $t(9.84), p<.01$ ) (a small-sized effect $r=.15$ ). Overall, these scores represent relatively high levels of intention to adopt personalized nutrition and functional foods.

\subsubsection{Testing the Structural Equation Model for Personalized Nutrition}

Appendix 1 presents the 27 factor loadings for all three samples. The theoretical model presented in Figure 1 was tested for personalized nutrition, wave 1, via a structural equation model (SEM) using Amos Version 7. However, the model was not identical to that presented in Figure 1. The results showed that the theoretical model was a borderline fit with the data for personalized nutrition, wave 1: $\chi^{2}(313)=4079.87, \mathrm{SRMR}=.08, \mathrm{TLI}=.91, \mathrm{RMSEA}=.077,90 \% \mathrm{CI}=.075-.079$. An inspection of the modification indices of the structural model suggested a significantly improved fit $\left(\Delta \chi^{2}(7)=2189.31, p<.001\right)$ by correlating the error terms of the involvement items interest and involved $(r=.41)$, the positive affect items optimistic and comfortable $(r=.56)$, the benefit items self and society $(r=-.78)$ and cost items self and society $(r=-.77)$, the costs and benefits items future generation $(r=-.28)$, the attitude items right and wise $(r=.39)$ and the behavioral intention items three and four: intention to adopt the diet to prevent disease and to improve quality oflife, respectively $(r=.53)$.

Given that being interested in and being involved with the new technology may be related, it was considered theoretically reasonable to include this correlation. Similarly, it was considered appropriate that being optimisticand being comfortableabout the technologymight be correlated with thinking positively about the technology. If costs and benefits for the individual can be seen as self-interest and costs or benefits for society as contributing to the common good, then it can be inferred that they would be negatively correlated. Since it is assumed that these technologies will be important for future generations in particular, it was considered appropriate that the cost to, and benefits for, future generations should negatively correlate. Finally, it was also considered possible that the intention to adopt a diet to prevent diseases and improve quality of life could correlate positively; the same was considered to be true for functional foods, that one's intention 
to buy food with extra positive health effects could correlate positively with an intention to eat functional foods.

The model containing all of these possible effects was tested and found to be a good fit with the data: $\chi^{2}(306)=1890.56$, SRMR $=.07$, TLI $=.96$, RMSEA $=.051,90 \% \mathrm{CI}=.048-.053$; Figure 2 presents the final model for intention to adopt personalized nutrition schematically. Estimates associated with each path represent standardized regression coefficients; the signs associated with all causal paths were in the expected direction.

\subsubsection{Tests of Model Replication}

For purposes of validation, the final model was tested for its replication across two other samples: a second wave of participants included in the personalized nutrition sample $(n=1528)$ and an independent sample for functional foods $(\mathrm{n}=2 \mathrm{O} 3 \mathrm{O})$. First, the model was tested again with both datasets separately and found to be a good fit (personalized nutrition, wave $2: \chi^{2}(306)=1636.61$, SRMR $=.07$, TLI $=.96$, RMSEA $=.053,90 \% \mathrm{CI}=.051-.056$; functional foods: $\chi^{2}(306)=1780.42$, $\mathrm{SRMR}=.06, \mathrm{TLI}=.96, \mathrm{RMSEA}=.050,90 \% \mathrm{CI}=.047-.052)$. Figure 2 shows the standardized regression coefficients associated with each path. Second, each specified causal path was constrained equally across calibration and validation samples and was then tested statistically. The judgment of replicability was based the goodness-of-fit of the constrained model. The results revealed both constrained models to be well-fitting (Personalized Nutrition wave 1 and $2, \chi^{2}(623)$ $=3544.95, \mathrm{SRMR}=.07, \mathrm{TLI}=.96, \mathrm{RMSEA}=.036,90 \% \mathrm{CI}=.035-.037$; Personalized Nutrition and Functional Foods, $\chi^{2}(623)=3959.06$, SRMR $=.09$, TLI $=.96$, RMSEA $=.037,90 \% \mathrm{CI}=.036-$ .038). These findings are evidence for the statistical equivalence of the model structure across dependent and independent samples ${ }^{1}$.

\subsubsection{Interpretation of the model}

The results in Figure 2 show that the most proximal predictors of intention were positive and negative affect and attitude. Those who felt more positive and less negative about the applications of the technology and had a positive attitude towards the applications of the technology were more likely to report that they intended to adopt the new technology.

Unexpectedly, the influence of negative affect on intention was low for all three models and not significant in the model for personalized nutrition, wave 1. Similarly, the direct effect of attitude on the intention to adopt the new technology was unexpectedly low in all models. The intention to adopt the new technology was largely predicted by positive affect.

There was also a strong indirect effect of involvement on the intention to adopt the applications of the new technology (personalized nutrition, wave 1: 0.66; personalized nutrition, wave 2: 0.66 ; functional foods: 0.70 ). This suggests that the reason involvement leads to stronger positive intentions is that participants felt good about personalized nutrition or functional foods. 
Figure 2.

Final model for Personalized Nutrition (wave 1 \& 2) and Functional Foods

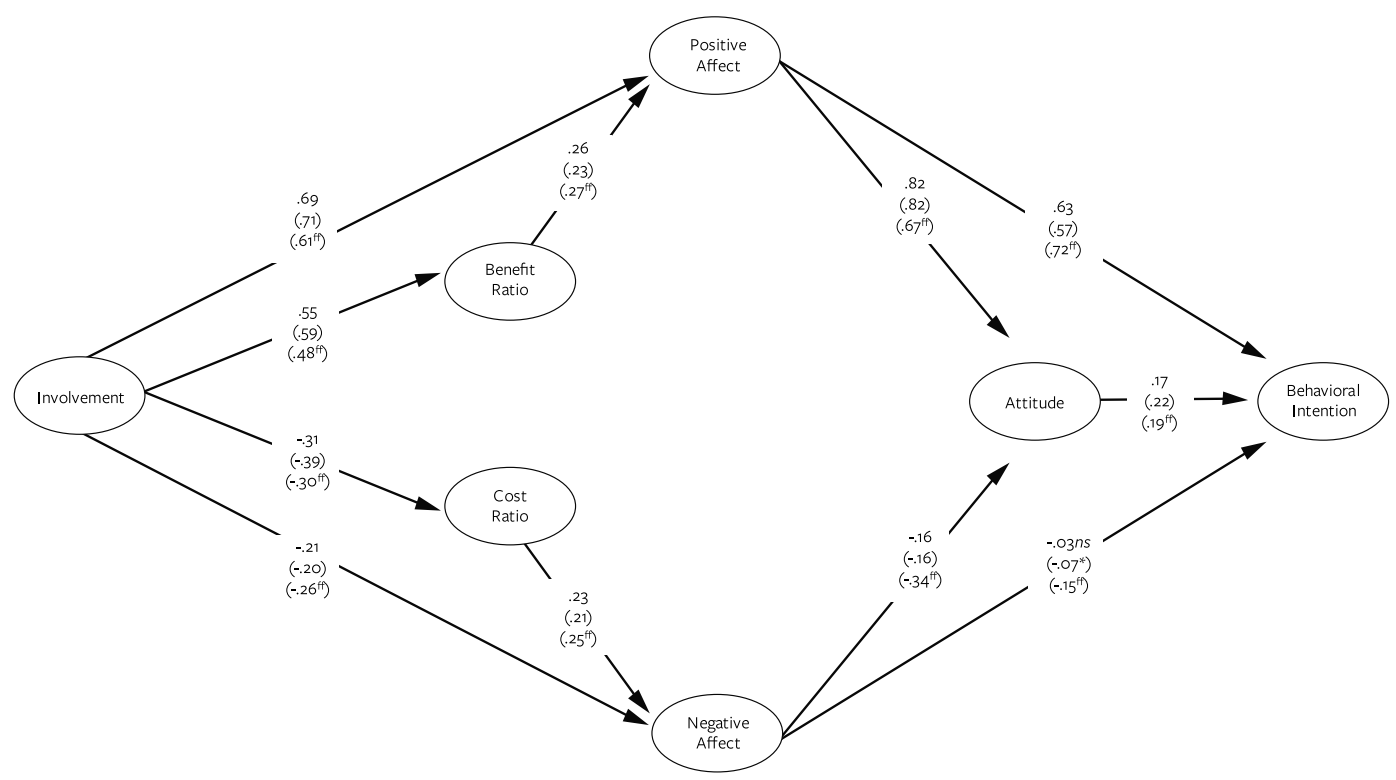

Note: Personalized Nutrition Wave 2 parameters are in parentheses; Functional Foods parameters are in parentheses and marked with ${ }^{~}$. All SRW's were significant at $\mathrm{p}<.001$ unless otherwise stated. ${ }^{*}=$ significant at $\mathrm{p}<.05$. ns = not significant at .05 .

Interestingly, the perceived costs and benefits only had a minor indirect effect on individuals' intentions (Perceived cost: personalized nutrition, wave 1: -0.02; personalized nutrition, wave 2: -0.02; functional foods: -0.05; Perceived benefits: personalized nutrition, wave 1: 0.20 ; personalized nutrition, wave 2: 0.17 ; functional foods: 0.23 ).

Figure 2 also suggests that positive, but not negative affect, was the most important driver of attitudes regarding the new technology. The indirect effect of involvement on attitude was very strong (personalized nutrition, wave 1: 0.73 ; personalized nutrition, wave 2: 0.74 ; functional foods: 0.60 ). Highly involved participants were more likely to adopt the technology and its applications because they felt more positive about it.

Squared multiple correlations provided information about the variance accounted for by the complete set of variables and showed that behavioral intention was accounted for (personalized nutrition, wave 1: 62\%; personalized nutrition, wave 2: 61\%; functional foods: $86 \%$ ). 


\subsection{Discussion}

This study has proposed, validated, and equated a socio-psychological model of intentions to adopting applications of new food technologies across two new developments: personalized nutrition and functional foods. The model explained $62 \%$ to $86 \%$ of the variance in participants' intention to adopt personalized nutrition and functional foods. As such, it has provided a foundation upon which to build and extend a theoretical model of the intention to adopt a new food technology.

The aim of this study was to develop and test a model that would predict intentions about personalized nutrition, including the determinants thought to influence the adoption process, namely cost and benefit ratio, positive and negative affect, attitude, and involvement. Furthermore, the stability of the model was validated using the same participants at two points in time. The generalizability of the model to another area of health and food choice was also tested. The model had a good fit for all three datasets.

The results suggest that involvement and positive affect are important factors related to behavioural intentions, at least in the domains investigated here. Involvement predicted both a cognitive process (the perception of costs and benefits) and an affective process (positive and negative affective evaluation). Positive and negative affect predicted individuals' attitudes and their intention to adopt the new technologies.

A dominant role for involvement and positive affect was identified. These seem to overrule the cognitive process and the negative pathway. Positive affect was a good predictor of intention. High levels of personal involvement was a reasonable predictor of affect (higher involvement and personal relevance result in more positive affect). The whole ratio part does not play a large role in the process. People do not seem to want to internalize cognitive processes. This could be explained by the fact that both technologies are new and people do not have much information at their disposal allowing them to weigh costs and benefits; therefore, they rely on their emotional responses to the technologies.

Specifically, positive affect leads to behavioral intentions (the effect of involvement was mediated largely by positive affect). Involvement could possibly be seen as the catalyst of the process, as introduced by Slovic, et al (2007)'s affect heuristic, emphasizing the importance of affect in guiding judgments and decisions as well as the reliance on rapidly and automatically affective responses (Loewenstein, Weber, Hsee, \& Welch, 2001; Zajonc, 1980). Recently, discussion has focused on the precise mechanism of the affect heuristic. Could an explanation for moments when the tide of public opinion suddenly turns be found in the affect heuristic, in light of the dual process theory? This study wants to contribute to this discussion. The construct of involvement was assessed with positively framed items only. It would be interesting to include negatively framed constructs in further research, those that can bring into play the more negative feelings participants may have: for example, the extent to which people perceive that they can personally control the risks and benefits of technology.

It was found that negative affect was not a good predictor of behavioral intention. The minor role 
of negative affect is unexpected, especiallybecause positive affect, a strong predictor, is measured in a compatible, opposed way. Although the terms "positive affect" and "negative affect" might suggest that these two mood factors are opposites (that is, strongly negatively correlated), they have, in fact, emerged as highly distinctive dimensions that can be meaningfully represented as orthogonal dimensions in factor-analytic studies of affect (Watson, Clark \& Tellegen, 1988).

Attitude was found to be a weak predictor of an individual's intention to adopt the novel applications of the two technologies. The direct effect of positive affect seems to overrule the formation of attitude. A possible explanation could be that attitude also includes many cognitive components and therefore is a weak predictor in the case of new technologies, in particular because low levels of involvement could mean people do not attend to information about the technologies.

The model was tested and compared at two points in time, with six months in between. The proposed model was found to be stable over time. Public opinion might be changed by an event, in particular one that is presented in a crisis context (for example, the Chernobyl disaster, or media reporting of the potentially negative consequences of GM foods), as can be explained as the social amplification of risk (Kasperson, et al, (1988). In the absence of such an event, no substantial change was found. The proposed model was found to be temporally stable, but external events might change the strength of positive and negative affect. For example, negative media coverage or reassuring information from a distrusted information source might increase negative affect. Negative affect has been shown to be an important determinant of risk attitude, possibly under circumstances where attitudes are less ambivalent. It would be interesting to test this model under external circumstances in which negative affect is stronger.

Behavioral intentions may be potentially formed in the absence of either involvement or affect. A question arises as to whether attitude activation is influential under these circumstances? Specifically, one might posit that attitude towards the new applications of technologies is derived from an earlier attitudes associated with previously experienced applications of technologies, such as in this case, genetically modified foods. The role of negative affect might be stronger if such attitudeactivation were to occur, as peoplewould beapplying negative attitudes experienced with GM foods to the new example of technology application.

The model was tested again using a comparable food technology: functional foods. The proposed model was shown to be generalizable to another new application of food technology, which suggests that the interrelationships between factors are reliable predictors of behavioral intention. However, functional foods represent a range of outcomes of different technologies and may form part of a personalized nutrition prescription; therefore the two types of applications are not independent of each-other, and so extensions to very different domains are needed.

The role of personal involvement is an important one and could be the key to the formation of the affectheuristic. Further research on what determines personal involvement could provide us with answers to the question of what affects this strong predictor of the intention to adopt emerging technologies in the nutrition field. A better understanding of these processes could allow us to foresee the development of public opinion and help us to anticipate it, instead of just passively 
observing its impact. Such information is invaluable for those individuals and institutions with responsibility for technology implementation, as evidence -based policies regarding innovation practices can be identified.

\section{Acknowledgments}

We acknowledge the financial support of the CSG (Centre for Society and Genomics) with gratitude. In this paper use is made of data of the LISS panel administered by CentERdata. The authors would like to thank the staff at CentERdata for their efforts in performing these surveys, as well as all those participants who kindly gave their time and participated.

\section{Notes}

1. As the model structure is found to be statistically equivalent across the independent samples of personalized nutrition and functional foods, an interesting follow-up question is whether the weight of the factors is statistically equivalent. As Amos does not provide the LM test (Lagrange Multiplier test (for releasing constraints)) to test equivalence of the structural paths across groups, further analyses were performed with EQS Version 6.1 (Bentler, 2006). An additional constrained model was computed; this model constrained all structural paths to be equal across groups. The probability level of the equality constraints was tested across the personalized nutrition group $(n=2030)$ and functional foods group $(n=1960)$, equality constraints with $\mathrm{p}<.05$ being untenable. The LM test showed that the strengths of three paths were not statistically equal: the path from Negative Affect to Behavioural Intention $\left(\chi^{2}=6.164, p<.05\right)$; from Involvement to Positive Affect $\left(\chi^{2}=7.113, p<.01\right)$ and from Negative Affect to Attitude $\left(\chi^{2}=23.327, \mathrm{p}<.001\right)$. Thus, in the case of functional foods the Negative Affect is a significantly stronger predictor of Attitude and Behavioural Intention and Involvement a significantly less strong predictor of Positive Affect than in the case of personalised nutrition. 


\section{References}

Afman, L., \& Muller, M. (2006). Nutrigenomics: From molecular nutrition to prevention of disease. Journal of the American Dietetic Association, 106(4), 569-576.

Ajzen, I. (2001). Nature and operation of attitudes. Annual Review Of Psychology, 52, 2758.

Bargh, J.A., Chaiken, S., Govender, R., \& Pratto, F. (1992). The generality of the automatic attitude activation effect. Journal of personality and social psychology, 62(6), 893-912.

Bentler,P.M., \&Wu,E.J.C. (2006).EQSfor Windowsstructuralequationprogrammanual. Encino, CA: Multivariate Software.

Boomsma, A. (2000). Teacher's Corner: Reporting Analyses of Covariance Structures. Structural Equation Modeling: A Multidisciplinary Journal, 7 (3), 461 - 483.

Bredahl, L. (2001). Determinants of Consumer Attitudes and Purchase Intentions With Regard to Genetically Modified Food - Results of a Cross-National Survey. Journal of Consumer Policy, 24(1), 23-61.

Browne, M. W., \& Cudeck, R. (1993). Alternative ways of assessing model fit. In K. A. Bollen \& J. S. Long (Eds.), Testing structural equation models (pp.136-162).

Castle, D., \& Ries, N. A. (2007). Ethical, legal and social issues in nutrigenomics: The challenges of regulating service delivery and building health professional capacity. Mutation Research-Fundamental and Molecular Mechanisms of Mutagenesis, 622(1-2), 138-143.

Clayton, E.W. (2003). Ethical, Legal, and Social Implications of Genomic Medicine. New England Journal of Medicine, 349, 6, 562-569.

Costa-Font, J., \& Mossialos, E. (2007). Are perceptions of 'risks' and 'benefits' of genetically modified food (in)dependent? Food Quality and Preference, 18(2), 173-182.

Darke, P. R., \& Chaiken, S. (2005). The pursuit of self-interest: Self-interest bias in attitude judgment and persuasion. Journal of Personality and Social Psychology, 89(6), 864-883.

Devcich, D. A., Pedersen, I. K., \& Petrie, K. J. (2007). You eat what you are: Modern health worries and the acceptance of natural and synthetic additives in functional foods. Appetite, 48(3), 333-337.

Dijksterhuis, A., \& Van Knippenberg, A. (1998). The relation between perception and behavior, or how to win a game of trivial pursuit. Journal of Personality and Social Psychology, 74(4), 865-877.

Diplock, A. T., Aggett, P. J., Ashwell, M., Bornet, F., Fern, E. B., \& Roberfroid, M. B. (1999). Scientific concepts of functional foods in Europe consensus document. British Journal of Nutrition, 81(4), S1-S27.

Eagly, A.H., \& Chaiken, S., (1993). The Psychology of Attitudes. Forth Worth, TX: Harcourt Brace.

Ferguson, M. J., Bargh, J. A., \& Nayak, D. A. (2005). After-affects: How automatic 
evaluations influence the interpretation of subsequent, unrelated stimuli.Journal of Experimental Social Psychology, 41(2), 182-191.

Frewer, L., Lassen, J., Kettlitz, B., Scholderer, J., Beekman, V., \& Berdal, K. G. (2004). Societal aspects of genetically modified foods. Food And Chemical Toxicology, 42 (7), 1181-1193.

Frewer, L. J., Scholderer, J., \& Bredahl, L. (2003). Communicating about the Risks and Benefits of Genetically Modified Foods: The Mediating Role of Trust. Risk Analysis, 23(6), 11171133 .

Flynn, R., \& Bellaby P., (Eds) (2007) Risk and the Public Acceptance of New Technologies; Palgrave Macmillan: Basingstoke, Hampshire, UK. pp 41-66

Garson, G.D. (2006). Statnotes: Topics in Multivariate Analysis. Retrieved October 9, 2006, from http://www2.chass.ncsu.edu/garson/pa765/strucur.htm

Gaskell, G., Allum, N., Wagner, W., Kronberger, N., Torgersen, H., Hampel, J., et al. (2004). GM foods and the misperception of risk perception. Risk Analysis, 24(1), 185-194.

Hasler, C. M. (2002). Functional foods: Benefits, concerns and challenges-a position paper from the American Council on Science and Health. Journal of Nutrition, 132(12), 3772-3781.

Holbert, R. L., \& Stephenson, M. T. (2002), Structural equation modeling in the communication sciences, 1995-2000. Human Communication Research, 28(4), 531-551.

Hoyle, R. H., \& Panter, A. T. (1995). Writing about structural equation models. In R. H. Hoyle (Ed.), Structural equation modeling: Comments, issues, and applications (pp. 158-176). Thousand Oaks, CA: Sage.

Hu, L.-T., \& Bentler, P. M. (1999). Cutoff criteria for fit indexes in covariance structure analysis: Conventional criteria versus new alternatives. Structural Equation Modeling, 6(1), 1-55.

Schumacher R.E. \& Lomax R.G. (1996) A beginner's guide to SEM. Lawrence Erlbaum Associates, Manwah, New Jersey, USA

Johnson, B. T., \& Eagly, A. H. (1989). Effects Of Involvement On Persuasion - A MetaAnalysis. Psychological Bulletin, 106(2), 290-314.

Johnson, B. T. (1994). Effects OfOutcome-Relevant Involvement And Prior Information On Persuasion. Journal Of Experimental Social Psychology, 30(6), 556-579.

Kasperson, R. E., Renn, O., Slovic, P., Brown, H. S., Emel, J., Goble, R., et al. (1988). The Social Amplification of Risk - a Conceptual-Framework. Risk Analysis, 8(2), 177-187.

Loewenstein, G. F., Weber, E. U., Hsee, C. K., \& Welch, N. (2001). Risk as feelings. Psychological Bulletin, 127(2), 267-286.

MacCallum RC.1986. Specification searches in covariance structure modelling. Psychol. Bull.100,107-20

Miles, S., \& Scaife, V. (2003). Optimistic bias and food. Nutrition Research Reviews, 16(1), 3-19.

Park, H. S., Levine, T. R., Westerman, C. Y. K., Orfgen, T., \& Foregger, S. (2007). The effects of argument quality and involvement type on attitude formation and attitude change: A test of dual-process and social judgment predictions. Human Communication Research, 33(1), 81102.

Petty, R. E., \& Cacioppo, J. T. (1986). The elaboration likelihood model of persuasion. In L. Berkowitz (Ed.), Advances in experimental social psychology (Vol. 19, pp. 123-205). San Diego, CA: Academic Press.

Pin, R.R., Critchley, C.M. \& Hardie, E.A., (Submitted). Understanding Public Perceptions of Personalized Nutrition: A Comparison of Australia and The Netherlands. 
Pin, R.R. \& Gutteling J.M. The Development of Public Perception Research in the Genomics Field - An Empirical Analysis of the Literature in the Field. Science Communication. Prepublished December 29, 2008; DOI: 10.1177/1075547008327273

Poortinga, W., \& Pidgeon, N. F. (2005). Trust in risk regulation: Cause or consequence of the acceptability of GM food? Risk Analysis, 25(1), 199-209.

Putten, van M.C., Frewer, L.J., Gilissen, L.J.W.J., Gremmen, B.G.J., Peinenberg, A.A. and Wichers, H.J. (2007) Novel Foods and food allergies. The issues. Trends in Food Science and Technology, 17(6), 289-299.

Ronteltap, A., van Trijp, J. C. M., \& Renes, R. J. (2008). Making nutrigenomics work Integrating expert stakeholder opinions and consumer preferences. Trends in Food Science and Technology, 19(7), 390-398.

Ronteltap,A., van Trijp, J.C.M., Renes, R.J., \&Frewer, L.J. (2007). Consumeracceptance of technology-based food innovations: Lessons for the future of nutrigenomics. Appetite, 49(1), $1-17$.

Schenck, M. Fischer, A., Jacobsen, E. and Frewer, L.J. (2008). Patient and non-patient attitudes to different mitigation strategies for birch pollen allergies and Oral allergy syndrome. Health Risk and Society. 10 (3), 263-282.

Siegrist, M. (2000). The influence of trust and perceptions of risks and benefits on the acceptance of gene technology. Risk Analysis, 20(2), 195-203.

Slamet-Loedin, I. H., \& Jenie, U. A. (2007). Nutrition: Ethics and social implications. In Nutrigenomics - Opportunities in Asia (Vol. 60, pp. 66-79). Basel: Karger.

Slovic, P., Finucane, M. L., Peters, E., \& MacGregor, D. G. (2007). The affect heuristic. European Journal of Operational Research, 177(3), 1333-1352.

Slovic, P., Peters, E., Finucane, M. L., \& MacGregor, D. G. (2005). Affect, risk, and decision making. Health Psychology, 24(4), S35-S4O.

Verschuren, P. M. (2002). Functional foods: Scientific and global perspectives. British Journal of Nutrition, 88(SUPPL. 2).

Watson, D., Clark, L. A., \& Tellegen, A. (1988). Development and Validation of Brief Measures of Positive and Negative Affect - the Panas Scales. Journal of Personality and Social Psychology, 54(6), 1063-1070.

Zajonc, R. B. (1980). Feeling and Thinking - Preferences Need No Inferences. American Psychologist, 35(2), 151-175. 


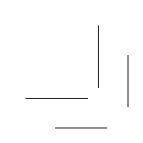

1 


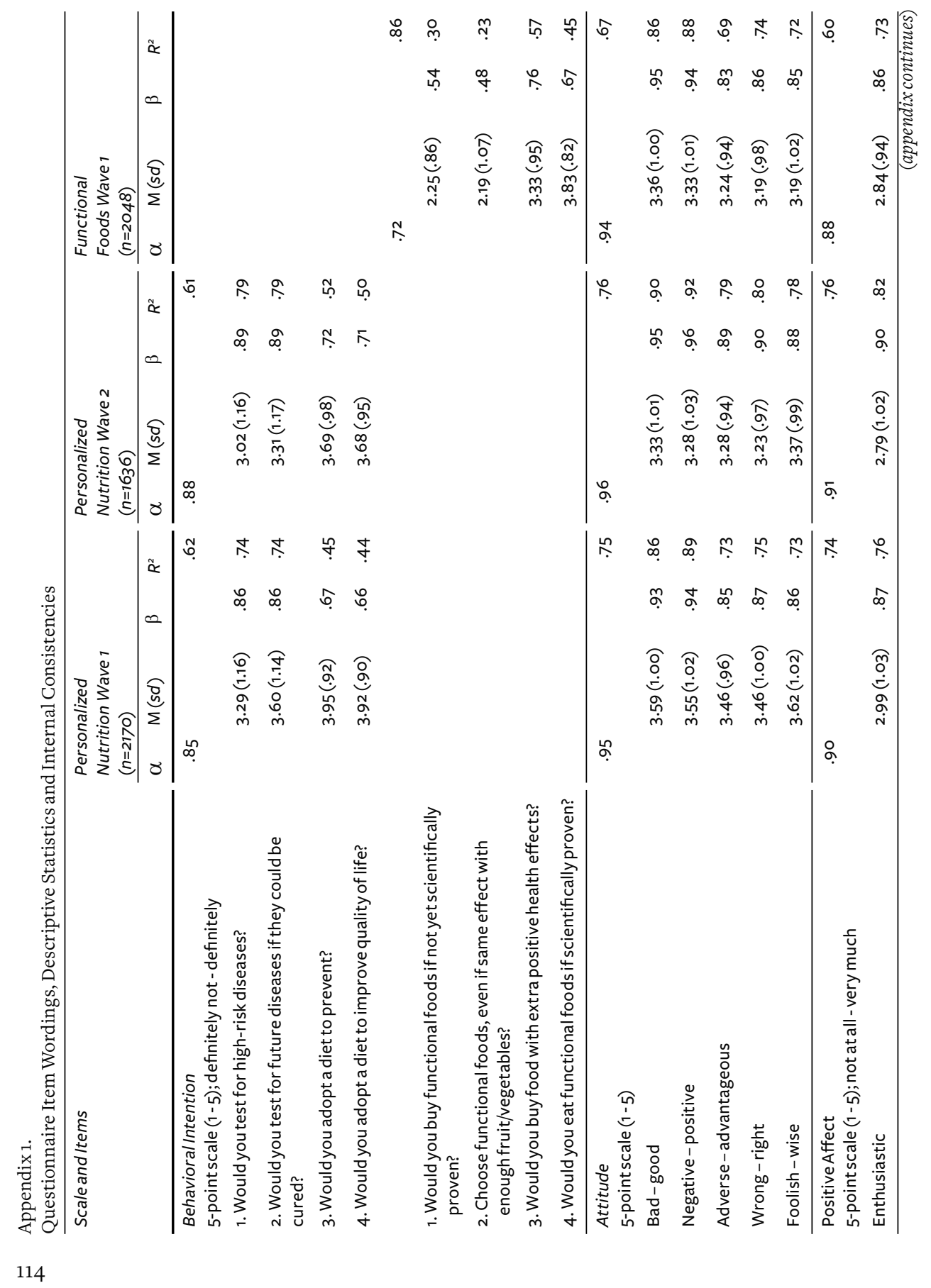




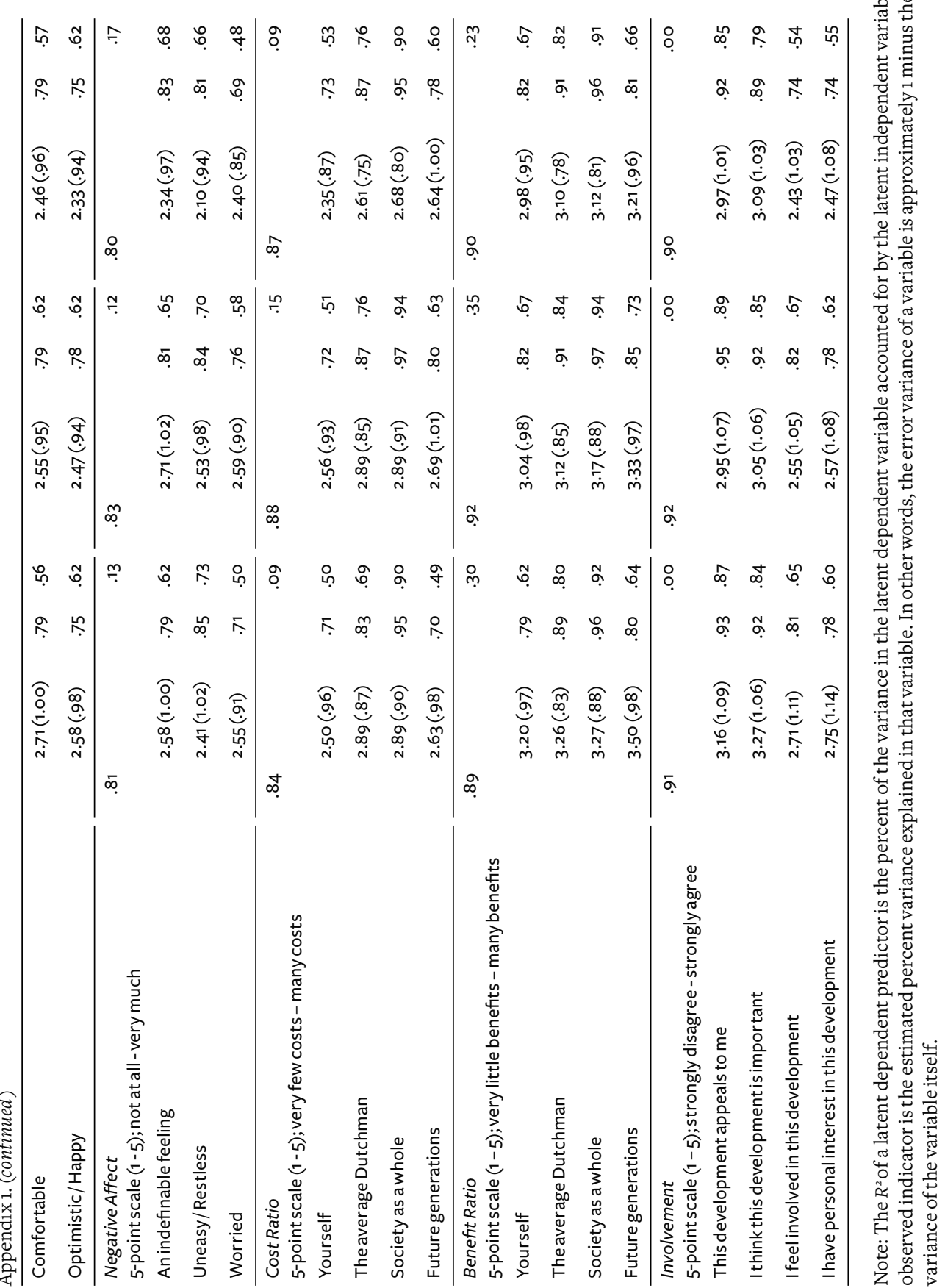




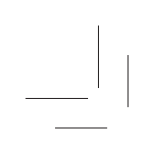

1 


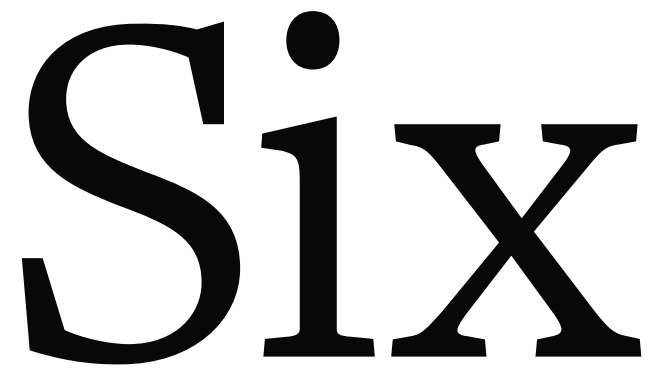

Discussion 


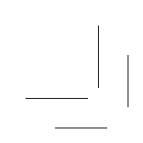

1 
The aim of this thesis is to identify which social psychological determinants contribute to the people's intention to adopt applications of the emerging technology of nutrigenomics. To this end, various research methods were employed. These include a systematic review of the literature to reveal the key social psychological determinants, cross-sectional analysis to reveal the most prominent predictors and underlying processes, and cross-national analysis, longitudinal data analysis, and multi-group analysis to test the temporal stability and external validity of the models developed.

The focus was, in particular, on identifying the relation between the cognitive and affective processes influencing behavioral intentions, and their relative importance in the case of an emerging food technology. The key questions asked related to identifying which processes were more dominant, and which underlying psychological determinants initiate these cognitive and affective processes. In particular, the role of trust and involvement was studied in depth.

First, this discussion chapter summarizes the theoretical implications pertinent to social psychology and communication from the studies that emerge in this thesis and identifies challenges for further research. Second, it focuses on the methodological aspects of the current research. Third, possible social policy implications of the findings for the introduction of nutrigenomics and other emerging technologies are discussed.

\subsection{Theoretical Implications: The Role of Affect, Trust and Involvement}

From the findings from the studies included in this thesis a few conclusions can be drawn on the predictors and processes in forming the intention to adopt new food technologies. The theoretical implications of three findings on the strongest predictors playing a key role in the models will be discussed below: the role of affect in relation to cognition, the limited importance of trust, and the role of personal involvement as a predictor for both cognitive and affective processes. Finally, a hypothetical model, integrating all findings from this thesis, is presented. 
Table 1

Predictors of reactions to genomics discussed in the four contributing papers

\begin{tabular}{|c|c|c|c|c|}
\hline & Chapter 2 & Chapter 3 & Chapter 4 & Chapter 5 \\
\hline Aim & $\begin{array}{l}\text { Important predictors } \\
\text { of reactions to } \\
\text { genomics }\end{array}$ & $\begin{array}{l}\text { Reactions to } \\
\text { Gene-technology }\end{array}$ & $\begin{array}{l}\text { Intention to adopt } \\
\text { Personalized } \\
\text { Nutrition }\end{array}$ & $\begin{array}{l}\text { Intention to adopt } \\
\text { Personalized } \\
\text { Nutrition } \\
\text { and Functional Foods }\end{array}$ \\
\hline Method & Systematic Review & Survey & $\begin{array}{l}\text { Survey, Cross- } \\
\text { national (The } \\
\text { Netherlands and } \\
\text { Australia) }\end{array}$ & $\begin{array}{l}\text { Survey, Longitudinal } \\
\text { \& External validation }\end{array}$ \\
\hline Result & Literature Review & Path Model & Structural Model & Structural Model \\
\hline \multirow[t]{7}{*}{ Predictors } & Experience & $x$ & & \\
\hline & Knowledge & $x$ & & \\
\hline & Trust & $x$ & $x$ & \\
\hline & $\begin{array}{l}\text { Cost/Benefit Ratio } \\
\text { and Perception }\end{array}$ & $x$ & $x$ & $x$ \\
\hline & Affect & $\mathrm{x}$ & $\mathrm{x}$ & $\mathrm{x}$ \\
\hline & $\begin{array}{l}\text { Personal Interest and } \\
\text { Involvement }\end{array}$ & $x$ & & $x$ \\
\hline & Attitude & & & $x$ \\
\hline
\end{tabular}

\subsubsection{The Important Role of Affect and its Relation to Cognition}

The role of affect and cognition in the intention to adopt new food technologies was addressed in all three models presented in this thesis (see Table 1) as these were expected to play key roles in predicting individuals intentions to adopt new food technologies.

Three main conclusions can be drawn from the research. First, the most proximal predictors of intention were positive and negative affect and attitude. As we demonstrated in Chapter 5 , those who felt more positive and less negative about the applications of nutrigenomics technology and had a positive attitude towards the applications of the technology were more likely to report that they intended to adopt the new technology. Second, the cognitive process does not play a large role. This could be explained by the fact that nutrigenomics technology is new and people do not have much information at their disposal allowing them to weigh costs and benefits; therefore, they rely on their affective or emotional responses to emerging technologies like nutrigenomics. The findings in another national setting, where possibly less information was available (Chapter 4), support this. Third, positive and negative affect influence behavioral intention independently. The extent to which an individual experiences positive affect rather than negative affect predicts an individual's intention to adopt new food technologies. However, the role of negative affect 
might be stronger if attitude activation were to occur: one might posit that attitude towards the new applications of (gene) technologies is derived from earlier attitudes associated with previously experienced applications of (gene) technologies such as, in this case, genetically modified foods. People would be applying negative attitudes experienced with GM foods to the new example of technology application, such as personalized nutrition. The results suggest that, at the time the research was conducted, positive affect was a much stronger predictor as it could be assumed that the food and medical context of the nutrigenomics technology - where people might relate to personal health and fitness - represent topics that are personally important to people.

The three models proposed in this thesis approach the role of affect from different perspectives and study affect in its different roles in the process of intention to adopt new food technologies. In the first model in Chapter 3 concern about the misuse of DNA information was found to be an outcome of the decision-making process rather than part of the process resulting in the intention to buy genetically modified food. Affect as an outcome of a decision-making process has been observed in other contexts as well (e.g., Horst et al. 2007, Bandura, 1989). This can be explained at a conceptual level, as the negative affect in this study was not related to the behavior (al intention) that is measured. When relating affect to the same behavior, the role of affect is a different one: predicting the behavioral intention (see Chapter 4 and 5). There has to be correspondence between affect and behavior, in that case both positive and negative affect predict the behavioral intention. Intention to adopt the new food technologies considered in the research was strongly predicted by positive affect, overruling a cognitive process of weighing up costs and benefits of the applications of nutrigenomics. The findings from the three models indicated that affect concerning a behavior is a strong predictor of that specific behavior, but, although not measured in Chapter 4 and 5 , there may always be a remainder emotional response. This is consistent with the theory of emotion (Bandura, 1989; Lazarus, 1993), where it is assumed that concern is another way of expressing reactions toward a phenomenon.

The measurement and focus on cognitive predictors is approached in three different perspectives in the three models described in this thesis. Thus potentially different ways of operationalizing the cognitive aspects in the process of intention to adopt new food technologies can be compared. In the first model (Chapter 3), the cognitive process utilized was assessed by measuring the perception of gene technology and measuring the factual knowledge. The perception of the consequences of gene technology was found to be a relatively strong predictor of the intention to buy genetically modified foods and the concern about misuse of DNA information. However, factual knowledge was found to play a negligible role (as did experience with the technology). In the second model, presented in Chapter 4 , the rational process in forming the intention to adopt a new technology was assessed with two separate constructs. Again perceptions of consequences of the introduction of the technology was included, but complemented with the general evaluation of costs and benefits. In the third model, presented in Chapter 5, the evaluation of costs was separated from the evaluation of benefits. Although perception of consequences of the introduction of a new technology was a strong predictor in the second model, some limitations in model development need to be mentioned. First, both positive and negative consequences were included in one construct, which makes differentiation in positive and negative processes difficult. Second, when developing a measurement instrument and a model that can be applied to 
other (new) (food) technologies, more general evaluations of costs and benefits of a technology are desirable to facilitate general applicability of the measurement scale. In the second model (Chapter 4), an overall evaluation of cost and benefit perceptions was included, measuring the way people trade-off perceptions of cost and benefit in decision-making of a technology. In Chapter 4, the scale used to measure cost/benefit provides a reliable overall evaluation of cost/ benefit perception of the new technology. However, in the last model (Chapter 5) the concepts of costs and benefit perceptions were measured separately. As personal involvement was a stronger predictor for perceived benefits than for perceived cost, it could be argued that these can be approached as two separate concepts and that a technology can have costs and benefits that can be rated separately by individuals.

In general, studies have demonstrated that affect and cognition influence attitudes (Breckler \& Wiggins, 1989; Crites et al., 1994; Trafimow \& Sheeran, 1998). However, as Keer et al. (2009) have reported, the impact of affect does not end at attitudes towards (the applications of) new technologies. Affect impacts intention directly, independently of attitude.

The role of affect in theories of decision-making is a much-debated topic. Whereas virtually all existing theories of decision- making about risk are cognitive in nature and, therefore, assume that people base their choices on rational and calculating judgments, (Loewenstein, Weber, Hsee, \& Welch, 2001, Lee, et al., 2005) the research presented here confirmed the importance of the role of affect in determining behavioral intention. As many studies about public attitudes towards science and technology have relied on cognitive explanations, social cognitive models have been criticized for not sufficiently considering affective influences on decision-making (e.g., Van der Plight, \& de Vries, 1998). From the studies described in this thesis, the role of the affect appears to be important, supporting the findings of others. The affect heuristic emphasizes the importance of affect in guiding judgments and decisions as well as the reliance on rapidly and automatically affective responses (Loewenstein et al., 2001; Slovic et al., 2007, Zajonc, 1980). Recently, discussion has focused on the precise mechanism of the affect heuristic. One conclusion is that emotions operate in parallel with cognition and can even override analytical reasoning (McComas, 2006). The distinction between the independent influence of positive and negative affect as proposed in this thesis is rather new and could shed more light on our understanding of this mechanism.

\subsubsection{The Role of Trust}

The role of trust, here defined as the willingness to rely on experts and institutions when managing risks and technologies, was included in the first two models presented in this thesis (Chapter 3 and 4 , see Table 1).

Trust was found to be an indirect predictor of the intention to adopt nutrigenomics via a cognitive process. People develop a perception of technology based on their trust in relevant actors in the field, and this affects their intention to adopt the (applications of the) new technology. These findings correspond with the findings of others (Frewer et al. 1996; Hansen, Holm, Frewer, Robinson \& Sandoe, 2003; Horst, Kuttschreuter \& Gutteling, 2007; Peters, Covello \& McCallum, 
1997; Slovic, 2000; Trumbo \& McComas, 2003). Trust predicted perceived benefits which, in turn, predicted the perception of consequences, leading to an emotional response and, finally, to an intention to adopt personalized nutrition. Thus, if respondents trusted scientists they were more likely to take a genetic test and adopt a diet because they believed that personalized nutrition would lead to desirable consequences and more benefits. Therefore, our results demonstrate the role of trust as a predictor of benefit perception, thus supporting the findings of Siegrist's model (2000). Siegrist (2000) demonstrated that trust in the companies and scientists conducting research on gene technologies has a strong effect on the risks and benefits perceived to be associated with those technologies.

Although trust is a concept that has frequently been identified as a determinant for perception and reactions to technology, (Frewer, Scholderer, \& Bredahl, 2003; Tanaka, 2004), it has also been found that trust is a consequence of information provision aligning with existing attitudes towards food technologies (Eiser, Miles \& Frewer, 2002). The models presented in this thesis suggest trust seems particularly to function as a strong predictor in the cognitive process. As we found that the cognitive process has limited influence on the intention to adopt personalized nutrition, the influence of trust on behavioral intention is indirect and limited.

\subsubsection{Personal Involvement as a Predictor of Cognitive and Affective Processes}

The role of involvement, personal interest in and relevance of the technology was studied in the first and last model presented in this thesis (Chapter 3 and 5 , see Table 1 ).

The level of involvement appeared as an important factor in the process of intention to adopt nutrigenomics. The construct involvement represented in this thesis refers to what Petty and Cacioppo (1986) termed "issue involvement" or "personal relevance" and refers to the extent to which a topic has personal meaning and important consequences for an individual. It is linked to personal interest as a result of the idea that the new technology can have significant consequences on one's own life (Apsler and Sears, 1968; Cho \& Boster, 2005; Andrews et al., 1990). The notion that a specific (application of a) new technology might affect one's well-being raises interest and relevance (Johnson, 2005; Celsi \& Olson, 1988) and that, in turn, makes one feel that the technological development could be important. The research reported in this thesis suggested that personal interest (Chapter 3) and, to a greater extent, involvement (Chapter 5) were strong predictors for both the cognitive and affective processes that lead to the intention to adopt the applications of an emerging new food technology. As such, involvement seems to reflect a strong predictor of behavioral intention in the context of implementation of emerging technologies, since it comprises elements such as relevance and interest. However, many questions on the precise function and role of involvement remain (see also Ter Huurne, 2008, p. 139). An in-depth understanding of the determinants of personal involvement and a clarification of its nature should be prioritized in further research in the field of public perception and behavioral intention concerning emerging technologies.

The role of knowledge about gene technology and experience with the technology was found to be less important in predicting reactions to gene technology (Chapter 3 ). In the case of an application 
of an emerging technological application such as such personalized nutrition, where even less consumer knowledge could be expected and personal experience of different applications level is low, the expected direct relationship of personal knowledge with behavioral intention might be predicted to be small. However, assuming people have more knowledge, experience and knowledge could be predictors for involvement with the technology, and therefore can be expected to have an indirect relationship with the intention to adopt new technologies. The process of how involvement is formed should be the topic of further research and could provide insights about what predicts the individual's involvement with a new technology.

\subsubsection{Future Research: Towards a New Model for the Intention to Adopt Emerging Food Technologies}

The systematic review of research on behavioral intention and the public perception of genomics shows a segmented field, with a broad range of incidental researchers and many journals paying attention to the topic. Empirical studies in which models and theories are put to the test are limited, but can provide a sound foundation for the further development of public perception research in the field of genomics. The models presented in this thesis are among the first to gain insight in the processes and predictors for the intention to adopt applications of nutrigenomics.

When integrating all the findings from this thesis into one hypothetical model, the emphasis is on the two-way process of affect and cognition (see Figure 2). Involvement is a predictor for both processes, whereas trust primarily influences the cost-benefit perception. This is in line with findings from other studies that find that trust is especially a strong predictor in the formation of risk perception. However, as the rational process in intention of adopting an emerging food technology is bypassed by an affective process, the role of trust for the behavior intention is not as strong as expected. Further research integrating and testing all constructs in one model should confirm the precise structure and (indirect) influences of the predictors on the individuals' intention to adopt new food technologies.

The findings in this thesis argue the necessity and the importance of the role of affect in theories of health-related decision making. Social cognitive models (e.g., Theory of Reasoned Action) are still valuable but might consider integrating affective influences on decision-making (e.g., Van der Pligt \& de Vries, 1998; French et al., 2005). This should be particularly considered in the case of emerging technologies where less information is available to stimulate cognitive processes. The findings in this thesis suggest that affect has a dominant role in influencing behavioral intention when compared to cognitive processes in the case of new food technologies. However, further research to clarify the precise role of affect in this context is needed, possibly focusing on testing the hypothesis in experimental designs that enable stronger conclusions on the causality. From our review of the literature, predictors such as perceptions of social norms and perceived self-efficacy did not reveal, but these could have a role in the process of the intention to adopt new food technologies. Further research should consider these predictors and test models that include these determinants.

The main structure of the proposed hypothetical model (Figure 1) was tested, and found to be 
temporally stable. It could also be extended to predict behavioral intention regarding adoption of the application of another food technology (Chapter 5). The question arises whether the model will hold over a longer period of time and for technologies associated with more societal negativity. In other words, will the model be durable, and could the model be more broadly applicable? Further research should test these issues.

Figure 1

Hypothetical Model for Intention to Adopt Emerging Food Technologies

Concluded from Contributing Studies

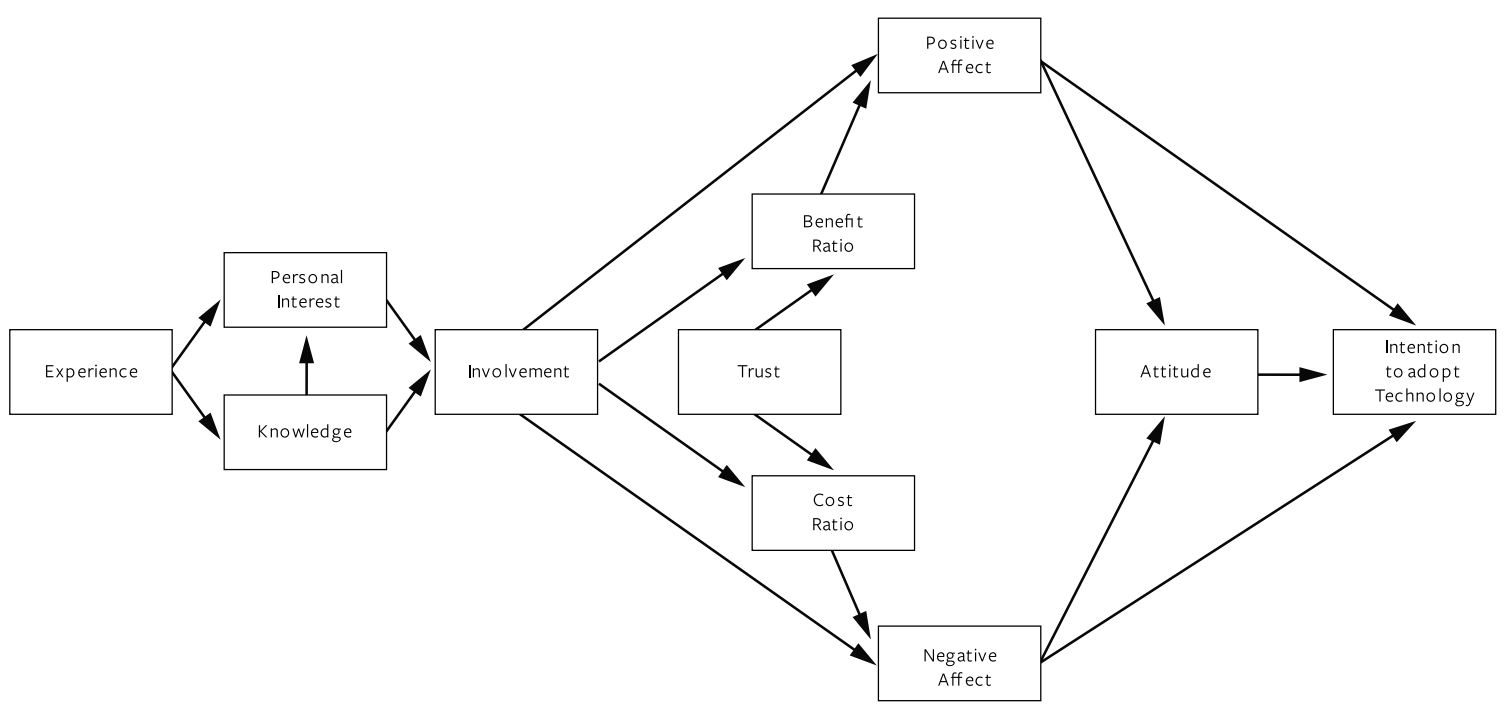

The question arises as to whether, in this stage of the development of nutrigenomics, people are addressed in the role of citizen or consumer. The difference concentrates on public support, that is, forming a judgment more or less without obligations, whereas consumers will or will not support a commercial application of a technology by buying products derived from it. In this early phase of development of nutrigenomics, this question is still unanswered. However, the model connects both attitudes as general evaluations of the technology to the behavioral intention to adopt the technology. Therefore, it accounts of the translation from public support for nutrigenomics to consumer acceptance concerning concrete applications of the new technology that people can, in theory, intentionally purchase.

Individuals play different roles - as consumers, citizens, or patients - and this means that at the transaction level, the processes by which individuals reach decisions about an application's risks, benefits, and the associated ethical considerations are more complex than those at the previous, information level, as the consequences these decision processes might have on the individual's behavior may have become clearer and involvement and commitment may have become stronger. Longitudinal survey research during different phases of introduction and implementation of new technologies in society can increase our understanding of these psychological processes. 


\subsection{Design and Methodology}

The aim of the thesis was to gain understanding which of the social psychological determinants contribute to the people's intention to adopt applications of the emerging technology of nutrigenomics. A systematic review of the literature (Chapter 2) revealed the key determinants, which were than tested in three different models (Chapter 3-5) using different structural equation modeling methodologies and different research designs.

\subsubsection{Design of the Studies: Validation and Temporally Stable Model}

The model in Chapter 3 was tested using a cross-sectional design (see Figure 2), which is a singleoccasion "snapshot" of a system of variables and constructs (MacCallum \& Austin, 2000). Since the measurement took place at a single point in time, it cannot be determined whether the conclusions are temporally stable and will apply in the long-term or in other settings.

The model in Chapter 4 was tested using a cross-national design (see Figure 2), testing the applicability of the model in two national settings: the Netherlands, where an extensive debate aboutgenetechnologytook placein the 1990s, and Australia, aWestern countrywitha comparable culture (Lewis, 2003) and values (Inglehart, Basanez, Deiz-Medrano, Halman, \& Luijkx, 2004), but with a different history of political and public controversies and media attention concerning gene technology (Salleh, 2008; Walls, Rogers-Hayden, Mohr, \& O’Riordan, 2005).

Figure 2

Design of Contributing Survey Studies and Corresponding Chapters

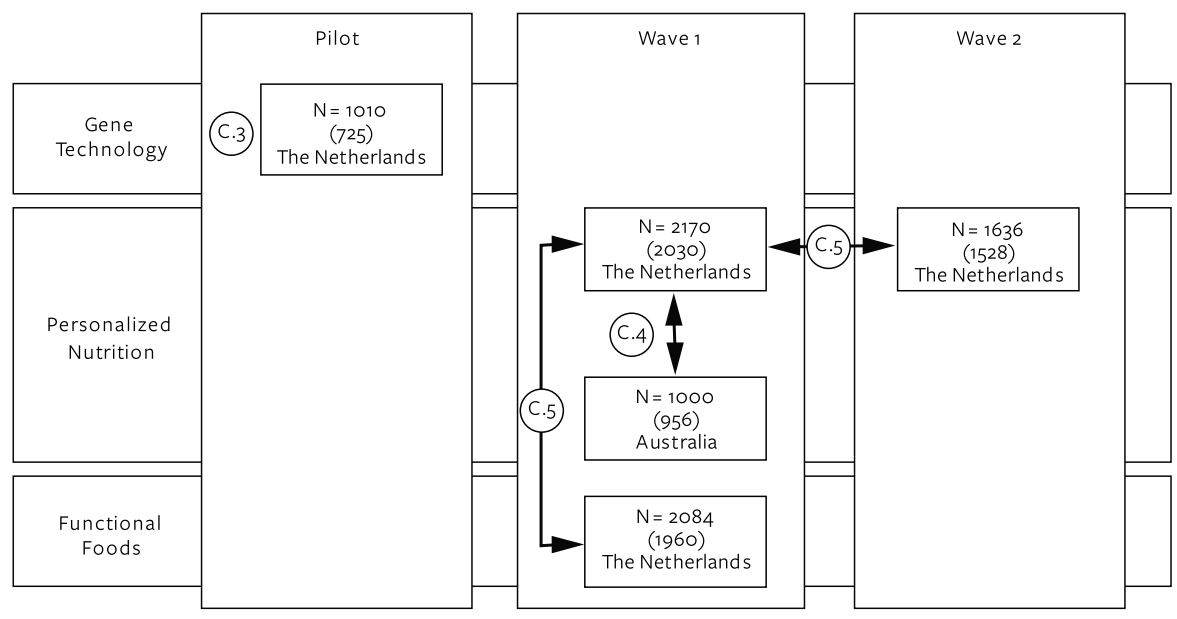

\footnotetext{
*The numbers in parentheses indicate the samples, not including outliers and missing values, used for structural equation modeling. In Chapter 5 the Dutch sample was 2109 (2025) because of a minimum age of 18 instead of 16 years was imposed in order to achieve comparability with the Australian sample.
} 
The model in Chapter 5 was tested using a longitudinal design (see Figure 2) to determine the temporal stability of the model. Temporal stability is an important characteristic in prospective studies that attempt to predict behavior at a later point in time. If measures of the theory's constructs lack temporal stability, they cannot be expected to predict later behavior (Aizen 2006). The model was tested and compared at two points in time six months apart and was found to be stable over time. Public opinion might be changed by an event, in particular one that is presented in a crisis context (for example, the Chernobyl disaster, or media reporting of the potentially negative consequences of GM foods) and can be explained by the social amplification of risk (Kasperson et al., 1988). External events might change the strength of positive and negative affect. For example, negative media coverage or reassuring information from a distrusted information source might increase negative affect. Negative affect has been shown to be an important determinant of risk attitude, possibly under circumstances where attitudes are less ambivalent. In the absence of such an event, no substantial change was found. It would be interesting to test this model under external circumstances in which negative affect is stronger.

Further, the model in Chapter 5 was tested and validated in the context of functional foods to test its utility for another new food technology. It could be argued that functional foods are strongly related to personalized nutrition as some examples may be based on the same technology. For example, in product development of next generation functional foods, nutrigenomics research could help to conclude certain nutrient have positive consequences on health at a much earlier stage than a more epidemiological investigation. Further research and testing against a completely different food technology - for example, high pressure processing - is needed to test the generic applicability of the model to the food technology domain. In addition, non-domainspecific tests of the model could be used to test for the generic applicability of the models to contribute to the relevant theory in general.

Further research could explore how public perception of nutrigenomics-based personalized nutrition may change over time and as a result of which underlying (psychological) mechanisms. This would require longitudinal research designs during the introduction and implementation of new technologies, with more than two waves of data collection and longer time-intervals. Further, to test the more general applicability of the model to other (new) technological areas, it would be interesting to test this model in other settings as well.

\subsubsection{Use of Structural Equation Modeling}

In this thesis, three models were tested using different applications of structural equation modeling (SEM). SEM is a statistical technique for testing and estimating causal relationships using a combination of statistical data and qualitative causal assumptions.

SEM is a frequently used data-analytic technique in social science research. This popularity is due to the unique capabilities and broad applicability of SEM and to recent advances in model and software development. However, the popularity and accessibility of SEM is matched by its complexities and ambiguities (Tomarken \& Waller, 2005). 
Among the strengths of SEM is the ability to model constructs as latent variables (variables which are not measured directly, but are estimated in the model from measured variables which are assumed to 'tap into' the latent variables). This allows the modeler to explicitly capture the unreliability of measurement in the model, which in theory allows the structural relations between latent variables to be accurately estimated. The hypothesized model can be tested statistically in a simultaneous analysis of the entire system of variables to determine the extent to which it is consistent with the data (Byrne, 2006). Furthermore, it takes a confirmatory rather than an exploratory approach to data analysis, and it provides methods for easily modeling multivariate relations and estimating point and/or interval indirect effects (Byrne, 2006). This sets SEM apart from the older generation of multivariate procedures.

As a data-analytic approach, SEM has a number of appealing features. SEM is not, however, a statistical magic bullet. It cannot be used to prove that a model is correct. In addition, even a wellfitting SEM model can have problematic lower-order components and omit important variables. Ironically, several of the limitations and misconceptions that have been identified have been well known to methodologists for many years (e.g., Breckler 1990, Cliff 1983, Freedman 1987, MacCallum et al. 1993) and arise in other statistical contexts (e.g., Judd et al. 1995). In a sense, then, one could describe SEM as a cutting-edge statistical technique that is subject to some very old and familiar problems, constraints, and misconceptions. It is important to be aware of both the strengths and limitations of SEM (Tomarken \& Waller, 2005).

Path analysis, as used in Chapter 3, is a form of multiple regression focusing on causality and represents a special case of SEM - one in which only single indicators are employed for each of the variables in the causal model (with a structural model, but no measurement model). In Chapters 4 and 5 a full structural model (with a structural model and a measurement model) was tested and additionally analyzed using multi group analysis. This is a technique for assessing whether certain aspects of a Structural Equation Model are the same across groups (e.g., in this case, different national backgrounds, different food technologies and two different points in time).

LISREL, AMOS, and EQS are three commonly used statistical packages for doing SEM (Kline, 1998). In this thesis both AMOS (Chapter 3 and 5) and EQS (Chapter 4 and 5) were used, as each of the packages offers a multitude of different features, therefore the choice was made depending on our needs and preferences for the specific analysis of the models, e.g., using EQS's LM test for the multi-group analysis in Chapter 4 (Schumacker \& Lomax, 2004, p. 8).

\subsection{Implications of the Findings for Policy}

The research presented in this thesis has identified some policyissues relevant to the introduction of a new technology such as nutrigenomics. While some food chain actors and members of the scientific community assume that nutrigenomics will ultimately enable the provision of personalized dietary advice, it is a science still in its infancy and the precise development of nutrigenomics technology is still uncertain (Muller \& Kersten, 2003). When looking at the mean scores, participants in the research presented here currently hold ambivalent-positive 
attitudes towards nutrigenomics, and have relatively high intentions to adopt applications such as personalized nutrition and functional foods.

This opens up new perspectives for the introduction and public support of these applications. From a public health perspective, it is now becoming important to understand whether the future use of nutrigenomics will also have positive implications for public health, for example through reducing the burden of disease. For example, substantial reduction in health service costs or improved quality of life at the population level measured in, for example, quality-adjusted life years may be a positive policy outcome. If this is the case, it may be useful to address the issue of positive affect through information provision.

\subsubsection{Importance of Affect: Prevent the Change of Sentiment}

If the affective process is dominant in predicting intentions to adopt nutrigenomics, this will have consequences for the implementation of the new technology in society. Governments, industry, scientists, healthcare professionals and other stakeholders focused on providing information and communicating the risks and benefits should take this into account when developing communication about nutrigenomics. However, affective processes are influenced by the extent to which an individual is personally involved with nutrigenomics. By implication, the increased personal relevance of a particular technology for an individual, the greater affective response (whether positive or negative) is invoked. It is these affective responses which will determine whether an individual's behavioral intentions are positive or negative.

Positive affect and negative affect were found to independently influence the intention to adopt new food technologies such as nutrigenomics. Therefore, promoting positive feelings is something different from preventing negative feelings, the first one being the most efficient to encourage adoption of nutrigenomics. However, the sentiment of the public can change, as we have seen in recent cases, such as the electronic health record (an individual patient's medical record in digital format connecting information from different healthcare providers, aiming at reducing medical errors and increase physician efficiency, but facing resistance because of privacy concerns). This change in sentiment can be triggered by attitude activation. Improving trust and personal involvement can be among the solutions to prevent the change of sentiment.

The public can be divided into three groups: a group that is positive toward the new technology of nutrigenomics, a group that is negative and a group that is ambivalent. From the perspective of industry, the first group is of interest. The people that are positive towards and have a high intention to adopt personalized nutrition can be the target group of marketing and product development and could be the first consumers of nutrigenomics products. From a governmental perspective, the people that are negative towards applications of nutrigenomics are of highest concern. The concerns this group has about applications of nutrigenomics should be addressed with regulation and legislation directed towards citizen protection. From a scientific perspective the ambivalent group is the most interesting, as social scientists can study the attitude development of this group because of e.g. attitude activation or monitoring changes in attitude, and attitude strength, with time. 


\subsubsection{The Issue of Trust: Information and Regulation}

The research presented in this thesis implies that trust has a limited importance in predicting an individual's intention to adopt nutrigenomics. Trust may, however, become more influential under circumstances where individual members of society are not motivated, or are unable, to seek out further information. Assuming individual members of society generally have limited access to information, personal ability or motivation, or resources to develop an understanding of the complexities of new or advanced technologies, they have to rely on those institutions for consumer and environmental protection. Higher levels of trust in experts or institutions may facilitate the process of public acceptance of a new technology. However, trust should be earned. If one does not guarantee that the public's concerns about (for example) the privacy issues (e.g. DNA storage), freedom of choice (e.g. in whether or not a particular individual knows the future probabilities of developing specific disease states), equality (e.g., in possibilities of obtaining health insurance and social divide of the healthy and unhealthy) and commercialization are undeserved, trust can be forfeit. The government can play a role regarding regulation and legislation directed towards citizen protection, but other stakeholders such as industry, healthcare professionals and scientists should take responsibility for providing trustworthy information about the technology and its applications.

\subsubsection{Importance of Personal Involvement: Addressing Personal Importance and the} Importance of the Development of Personally Relevant Applications

Judging from the research presented in this thesis, the level of involvement appeared as an important factor in the process of intention to adopt nutrigenomics. It would be valuable to stimulate the general public's interest in the topic by addressing the personal importance of new food technologies in order to gain a higher level of engagement with the topic. This will motivate people to think and feel more thoroughly about the issue before they form an intention to adopt - or not adopt - the new technology.

What is involvement and how can it be improved? On the one hand, involvement can be influenced by information and communication on how an emerging technology can be personally relevant for an individual (e.g., personalized nutrition for an individual with a family history of diabetes or obesity). News media and popular media, such as the Internet and magazines, all of which anticipate health trends could play a role in this process, influencing the personal interest, knowledge and (indirect) experience with this new technology. On the other hand, involvement could be partly intrinsic, coming with an individual's characteristics, circumstances and lifestyle (e.g., for a patient, developments can improve one's quality of life).

A technology might or might not be relevant for an individual. This implicates that the development of an emerging technology should stem from the law of supply and demand. The public as the final consumer should therefore be heard to modify the applications of the technology on the needs and wishes of the consumer. As nutrigenomics could be characterized as push technology, technological possibilities are important drivers for the development of the technology. However, to stimulate development of applications that are personally relevant, technology should be used 
as a tool to solve people's problems as they are experienced and perceived by those individuals. From a policy perspective, this should result in a proactive approach by, for example, applying participatory democracy tools such as public participation to explore various policy options and emergence of values. This way, involvement can be improved and the development of applications of the technology can be modified in a way that they become more personally relevant for the individual.

\subsection{Final Conclusions}

The public perception research in the field of the emerging technology genomics is, as yet, not well advanced. This thesis is one of the first attempts to fill the gap of our understanding of the socio-psychological process that leads to the intention to adopt applications of the emerging food technology nutrigenomics. The findings support the affect heuristic: an individual tends to rely more on his or her affective response when forming an intention to adopt, for example, personalized nutrition, as compared to a cognitive process linked to rationality. Involvement and personal relevance of the technology is an important predictor for both the affective and cognitive processes. Trust, a determinant frequently studied in the last decade, is a good predictor of cost and of benefit perceptions and has less influence on the intention to adopt an emerging technology than was expected. When introducing a new technology, under the conditions of public support, the personal relevance of the applications of the new technology should be addressed. A proactive policy approach can stimulate the development of applications of a technology that are personally relevant for individuals. 


\section{References}

Ajzen, I. (2006). Constructing a TpB questionnaire: Conceptual and methodological considerations. Retrieved February 16, 2009, from http://people.umass.edu/aizen/pdf/tpb. measurement.pdf

Andrews, J. C., Durvasula, S., \& Akhter, S. H. (1990). A Framework for Conceptualizing and Measuring the Involvement Construct in Advertising Research. Journal of Advertising, 19(4), 27-40.

Apsler, R., \& Sears, D. O. (1968). Warning Personal Involvement and Attitude Change. Journal of Personality and Social Psychology, 9 (2P1), 162-\&.

Bandura, A. (1989). Human Agency in Social Cognitive Theory. American Psychologist, 44(9), 1175-1184.

Breckler, S. J. (1990). Applications of Covariance Structure Modeling in Psychology Cause for Concern. Psychological Bulletin, 107(2), 260-273.

Byrne, B. M. (2006). Structural Equation Modeling with EQS: Basic Concepts, Applications and Programming (Second ed.). Mahwah, New Jersey/London: Lawrence Erlbaum Associates.

Cho, H., \& Boster, F. J. (2005). Development and validation of value-, outcome-, and impression-relevant involvement scales. Communication Research, 32(2), 235-264.

Cliff N. 1983. Some cautions concerning the application of causal modeling methods. Multiv. Behav. Res. 18:81-105

Eiser, J. R., Miles, S., \& Frewer, L. J. (2002). Trust, perceived risk, and attitudes toward food technologies. Journal of Applied Social Psychology, 32(11), 2423-2433.

Freedman, D. A. (1987). As Others See Us - a Case-Study in Path-Analysis. Journal of Educational Statistics, 12(2), 101-128.

French, D. P., Sutton, S., Hennings, S. J., Mitchell, J., Wareham, N. J., Griffin, S., et al. (2005). The importance of affective beliefs and attitudes in the theory of planned behavior: Predicting intention to increase physical activity. Journal of Applied Social Psychology, 35(9), 18241848.

Frewer, L., Howard, C., Hedderley, D., \& Shepherd, R. (1996). What determines trust in information about food-related risks? Underlying psychological constructs. Risk Analysis, 16(4), 473-486.

Frewer, L. J., Scholderer, J., \& Bredahl, L. (2003). Communicating about the Risks and Benefits of Genetically Modified Foods: The Mediating Role of Trust. Risk Analysis, 23(6), 11171133 .

Hansen, J., Holm, L., Frewer, L., Robinson, P., \& Sandoe, P. (2003). Beyond the knowledge deficit: recent research into lay and expert attitudes to food risks. Appetite, 41(2), 111-121.

Horst, M., Kuttschreuter, M., \& Gutteling, J. M. (2007). Perceived usefulness, personal experiences, risk perception and trust as determinants of adoption of e-government services in 
The Netherlands. Computers in Human Behavior, 23(4), 1838-1852.

Inglehart, R., Basanez, M., Deiz-Medrano, J., Halman, L., \& Luijkx, R. (2004). Human Beliefs and Values: A Cross-Cultural Sourcebook based on the 1999-2002 values Surveys. Mexico City: Siglo XXI.

Johnson, B. B. (2005). Testing and expanding a model of cognitive processing of risk information. Risk Analysis, 25(3), 631-650.

Judd, C. M., McClelland, G. H., \& Culhane, S. E. (1995). Data-Analysis - Continuing Issues in the Everyday Analysis of Psychological Data. Annual Review of Psychology, 46, 433-465.

Kasperson, R. E., Renn, O., Slovic, P., Brown, H. S., Emel, J., Goble, R., et al. (1988). The Social Amplification of Risk - a Conceptual-Framework. Risk Analysis, 8(2), 177-187.

Keer, M., Putte, v. d., B., \& Neijens, P. (2009). The Role of Affect and Cognition in Health Descision Making. Paper presented at the Etmaal van de Communicatiewetenschap, Nijmegen, The Netherlands, 13 February, 2009.

Kline, R. B. (2005). Principles and practice of structural equation modeling (Second ed.). New York The Guilford Press.

Lazarus, R. S. (1993). Coping Theory and Research - Past, Present, and Future. Psychosomatic Medicine, 55(3), 234-247.

Lee, C. J., Scheufele, D. A., \& Lewenstein, B. V. (2005). Public attitudes toward emerging technologies - Examining the interactive effects of cognitions and affect on public attitudes toward nanotechnology. Science Communication, 27(2), 240-267.

Lewis, R. D. (2003). The Cultural Imperative: Global Trends in the 21st Century. Maine: Intercultural Press, Inc.

Loewenstein, G. F., Weber, E. U., Hsee, C. K., \& Welch, N. (2001). Risk as feelings. Psychological Bulletin, 127(2), 267-286.

MacCallum, R. C., \& Austin, J. T. (2000). Applications of structural equation modeling in psychological research. Annual Review of Psychology, 51, 201-226.

Maccallum, R. C., Wegener, D. T., Uchino, B. N., \& Fabrigar, L. R. (1993). The Problem of Equivalent Models in Applications of Covariance Structure-Analysis. Psychological Bulletin, 114(1), 185-199.

McComas, K. A. (2006). Defining moments in risk communication research: 19962005. Journal Of Health Communication, 11(1), 75-91.

Muller, M., \& Kersten, S. (2003). Nutrigenomics: goals and strategies. Nature Reviews Genetics, 4(4), 315-322.

Peters, R. G., Covello, V. T., \& McCallum, D. B. (1997). The Determinants of Trust and Credibility in Environmental Risk Communication: An Empirical Study. Risk Analysis, 17(1), 4354 .

Petty, R. E., \& Cacioppo, J. T. (1986). The elaboration likelihood model of persuasion. In L. Berkowitz (Ed.), Advances in experimental social psychology (Vol. 19, pp. 123-205). San Diego, CA: Academic Press.

Salleh, A. (2008). The fourth estate and the fifth branch: the news media, GM risk, and democracy in Australia. New Genetics and Society, 27(3), 233-250.

Schumacker, R. E., \& Lomax, R. G. (2004). A Beginner's Guide to Structural Equation Modelling (2nd ed.). London: Lawrence Erlbaum Associates, Inc.

Siegrist, M. (2000). The influence of trust and perceptions of risks and benefits on the acceptance of gene technology. Risk Analysis, 20(2), 195-203. 
Slovic, P. (2000). The perception of risk. London: Earthscan Publications.

Slovic, P., Finucane, M. L., Peters, E., \& MacGregor, D. G. (2007). The affect heuristic. European Journal of Operational Research, 177(3), 1333-1352.

Tanaka, Y. (2004). Major psychological factors affecting acceptance of generecombination technology. Risk Analysis, 24(6), 1575-1583.

Ter Huurne, E. F. J. (2008). Information Seeking in a Risky World: The Theoretical and Empirical Development of FRIS: A Framework of Risk Information Seeking. University of Twente, Enschede.

Tomarken, A. J., \& Waller, N. G. (2005). Structural equation modeling: Strengths, limitations, and misconceptions. Annual Review of Clinical Psychology, 1, 31-65.

Trumbo, C. W., \& McComas, K. A. (2003). The Function of Credibility in Information Processing for Risk Perception. Risk Analysis, 23(2), 343-353.

Van der Pligt, J., \& De Vries, N. K. (1998). Expectancy-value models of health behaviour: The role of salience and anticipated affect. Psychology \& Health, 13(2), 289-305.

Walls, J., Rogers-Hayden, T., Mohr, A., \& O'Riordan, T. (2005). Seeking citizens' views on GM crops: Experiences from the United Kingdom, Australia, and New Zealand. Environment, $47(7), 22-36$.

Zajonc, R. B. (1980). Feeling and Thinking - Preferences Need No Inferences. American Psychologist, 35(2), 151-175. 

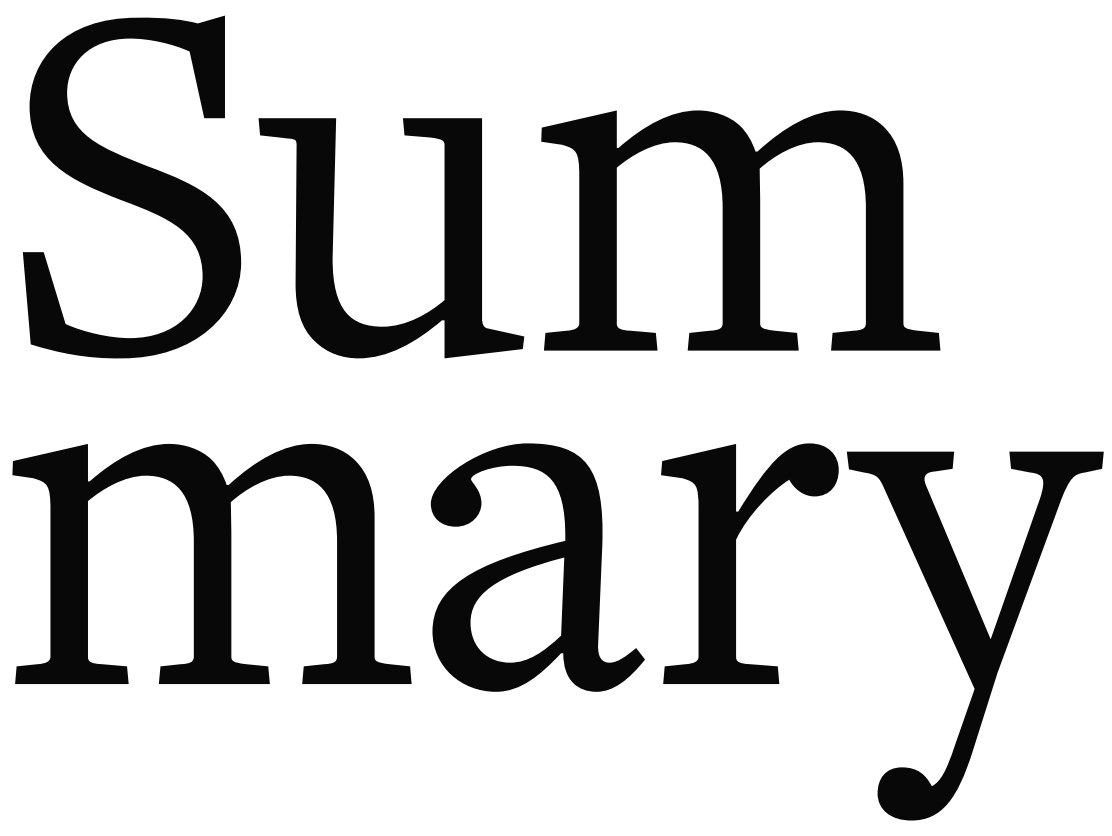


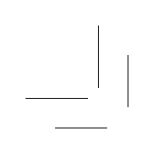

1 


\section{Summary}

Would you take a genetic test in order to know to what diseases you have an increased risk of developing in order to obtain a prescription for a personalized diet to prevent these future diseases?

Public support is an important and necessary condition for the successful introduction of a new technology and its applications in society. If nutrigenomics technology can be used to predict diseases and prescribe preventive diets based on a person's genetic profile, it is important to understand the people's intention to adopt such personalized diets. In this dissertation research, intentions regarding the adoption of nutrigenomics were examined next to the role of potentially influential psychological determinants of a person's decision to adopt applications of nutrigenomics technology.

In the first study (Chapter 2), the scientific literature regarding public perception of genomics was systematically reviewed. In total, 451 journal articles were analyzed, all published between 1970 and 2006. The results indicate that the research field is relatively young, with an increasing popularity during the last decade which reflects the same curve as media coverage of genomics technology. Many authors have studied the public perception of genomics, but only a small number published frequently. There is a strong focus on food and agricultural genomics, and a separate body of literature focuses on medical genomics. This finding corresponds with a division between the European Union (focus on public perceptions of food and agriculture genomics) and the United States (focus on public perceptions of medical genomics). A broad range of determinants that possibly influence the public perception of genomics is identified in this review, such as experience with the technology, knowledge about the technology, trust in government and other relevant institutions, weighing costs and benefits, more emotional or affective reactions, personal interest and involvement, and attitude. However, hypotheses concerning the possible influence of these psychological determinants were not always tested in previous research. Empirical studies in which models and theories are put to the test are lacking. In the following studies, these predictors are tested in three models starting from a broad range of predictors, focusing on the strongest predictors and most important processes.

In Chapter 3, individual reactions to gene technology (that is, an individual's intention to buy genetically modified foods, worry about abuse of DNA information, and people's preferences for different actors and institutions to be able to influence decisions) were studied. A path model, studying the relationship between these reactions and perception of the technology, trust, experience, knowledge and personal interest, was tested using a representative sample of the Dutch population $(n=1010)$. The survey revealed that a large segment of the public was 
concerned about the abuse of DNA information, was not willing to buy genetically modified food, and wanted relevant actors to have an influence on legislation and enforcement. Path analysis demonstrated that these reactions can be explained using a generic model that describes the underlying determinants for reactions to various applications of gene technology. It was concluded that trust in authorities, personal interest in gene technology, and perceptions of gene technology are important predictors of people's reactions, whereas experience and knowledge are less important.

In Chapter 4 the influence of affective evaluations, rational cognitions, and social trust on an individual's intentions to adopt personalized nutrition were examined. Data from representative community samples in the Netherlands $(\mathrm{n}=2109)$ and Australia $(\mathrm{n}=1000)$ were utilized. Structural equation modeling was applied to explore how such intentions were formed. Although the final model showed a good fit for both Dutch and Australian populations, an important cross-national difference emerged. Among Australians, positive emotion was a substantial predictor of an individual's intention to adopt a personalized nutrition program whereas rational considerations were more important predictors among the Dutch. A possible explanation could be that individuals from countries where information is provided, as in The Netherlands, are more likely to base their intention on rational considerations, while those given less information, like Australians, rely on affective evaluations.

Chapter 5 focuses on the influence of positive and negative affect associated with the nutrigenomics technology, cost and benefit perception, attitude, and personal involvement on the intention to adopt personalized nutrition. The theoretical model, tested using data collected from a representative sample in The Netherlands $(\mathrm{n}=2109)$, showed a good fit. The results show that the higher an individual's involvement in personalized nutrition is, the more positive he or she is about it, and the higher is his or her intention to adopt it. The model was replicated and validated six months later $(n=1636$ of the original sample) and showed to be temporally stable. The utility of the model in another area of food technology, functional foods, was also tested and validated ( $\mathrm{n}=2084$, new sample).

The public perception research in the field of the emerging technology genomics is, as yet, not well advanced. This thesis is one of the first attempts to fill the gap of our understanding of the socio-psychological process that leads to the intention to adopt applications of the emerging food technology nutrigenomics. The findings support the affect heuristic: an individual tends to rely more on his or her affective response when forming an intention to adopt, for example, personalized nutrition, as compared to a cognitive process linked to rationality. Involvement or personal relevance of the technology is an important predictor for both the affective and cognitive processes. Trust, a determinant frequently studied in the last decade, is a good predictor of cost and benefit perceptions, and, has less influence on the intention to adopt an emerging technology than was expected. When introducing a new technology, under the conditions of public support, the personal relevance of the applications of the new technology should be addressed. A proactive policy approach can stimulate the development of applications of a technologythat are personally relevant for individuals and therefore are positively valued. 

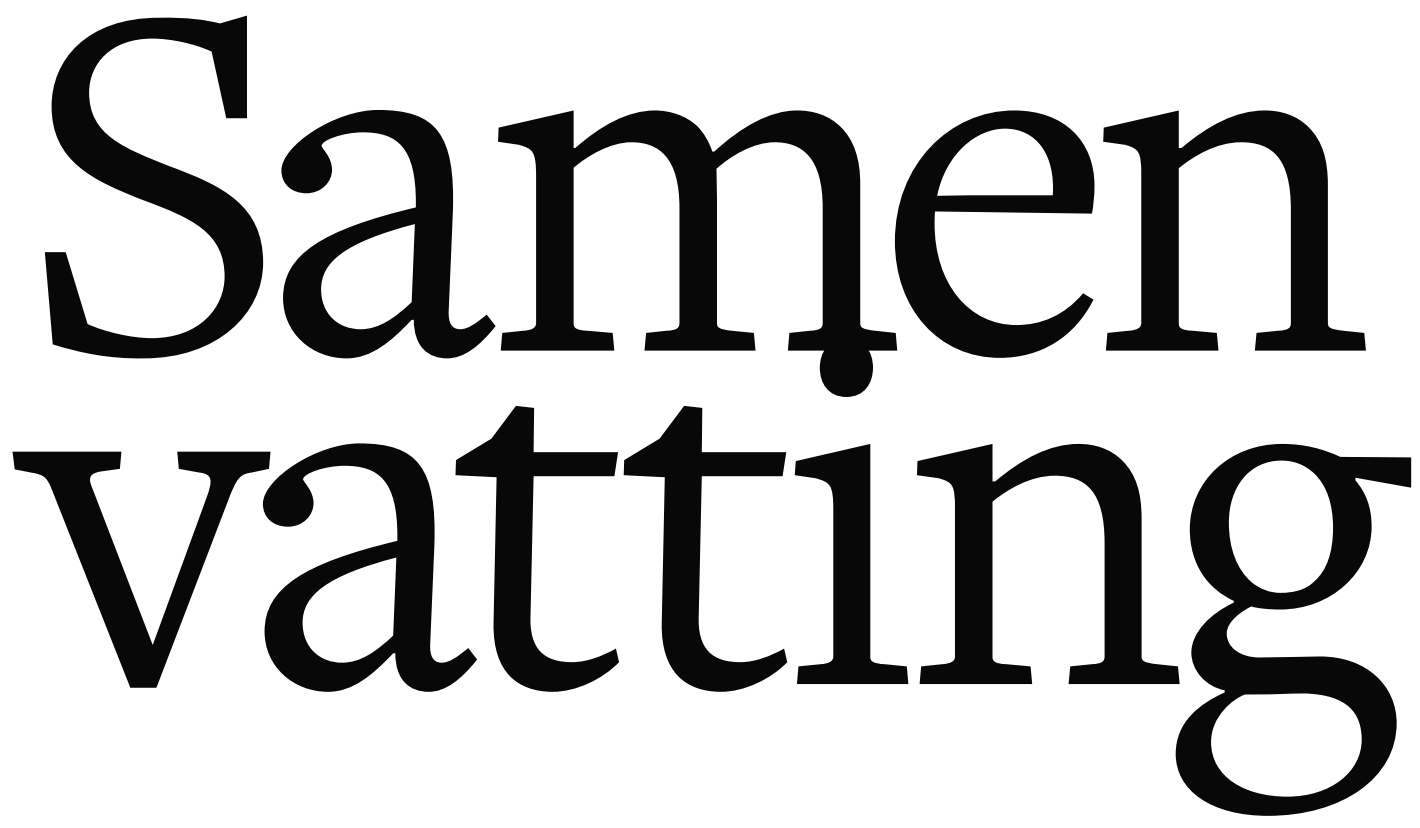


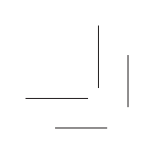

1 


\section{Samenvatting}

Zou je een genetische test willen doen, zodat je weet op welke ziekten je een verhoogd risico loopt en een persoonlijk dieet voorgeschreven willen krijgen om deze toekomstige ziekten te voorkomen?

Maatschappelijk draagvlak is een essentiële voorwaarde voor het succes van een nieuwe technologie en haar toepassingen. Als voedingsgenomics technologie kan worden gebruikt om ziekten te voorspellen en preventieve diëten voor te schrijven op basis van een persoonlijk genetische profiel, is het belangrijk om te begrijpen hoe het publiek zich een mening vormt over een dergelijk persoonlijk dieet. In dit proefschrift is gekeken naar de intentie van het publiek om toepassingen van voedingsgenomics te gaan gebruiken, en naar het sociaal psychologisch proces dat daaraan vooraf gaat. Welke factoren voorspellen gedragsintentie en welke processen spelen hierbij een rol?

Hoofdstuk 2 geeft een overzicht van het relevante academisch onderzoek over publieke perceptie van genomics in het algemeen, gepubliceerd tussen 1970 en 2006. In deze systematic review zijn in totaal 451 wetenschappelijke artikelen geanalyseerd. De resultaten laten een stijgende populariteit van onderzoek naar dit onderwerp zien in het laatste decennium. Die is vergelijkbaar met de populariteitscurve van het onderwerp in de media. Veel auteurs bestuderen de publieke perceptie van genomics, maar slechts een klein aantal auteurs heeft hierover meerdere malen gepubliceerd. In de artikelen ligt een sterke nadruk op voedingsgenomics. Er is een apart domein van auteurs en wetenschappelijke tijdschriften die aandacht besteden aan genomics over medische aspecten. Deze bevindingen corresponderen met een scheiding tussen de EU (waar onderzoek zich met name richt op de perceptie van voedings- en landbouwgenomics) en de VS (waar onderzoek zich met name richt op de perceptie van medische genomics). Uit de systematic review komt een scala van onderzochte voorspellers van publieke perceptie naar voren, waaronder: ervaring met de technologie, kennis over de technologie, vertrouwen in de overheid en andere betrokken instanties, de cognitieve kosten-baten afweging, de emotionele of affectieve reactie, persoonlijke interesse en/of betrokkenheid en attitude. Toch is er nog nauwelijks empirisch onderzoek gedaan naar de rol van deze factoren. Daarom zijn in de vervolgstudies in dit proefschrift deze voorspellers in drie statistische modellen getoetst, startend vanuit een breed scala aan factoren in het eerste model, concentrerend op de belangrijkste voorspellers en processen in het laatste model.

In hoofdstuk 3 wordt het verband onderzocht tussen de voorspellers perceptie, vertrouwen, ervaring, kennis en persoonlijke interesse en drie reacties op gentechnologie in het algemeen. De drie reacties (namelijk de intentie om genetisch gemodificeerde voeding te kopen, zorgen over 
misbruik van de technologie, en de wens dat relevante instanties inspraak hebben op besluiten over de technologie) en de voorspellers ervan, zijn gemeten in een publieksonderzoek onder de Nederlandse bevolking $(n=1010)$. Deresultaten laten zien dat veel mensen bang zijn voor misbruik van DNA-informatie, dat ze niet bereid zijn om genetisch gemodificeerde voedselproducten te kopen, en dat ze het wenselijk vinden dat relevante instanties invloed hebben op de wetgeving en de handhaving rondom gentechnologie. De analyses tonen aan dat deze reacties goed te verklaren zijn met een algemeen model dat de onderliggende determinanten voor reacties op verschillende toepassingen van gentechnologie beschrijft. Belangrijke voorspellers van de reacties van individuen zijn het vertrouwen in autoriteiten, de persoonlijke interesse in gentechnologie en perceptie van gentechnologie, terwijl ervaring en kennis minder belangrijk zijn.

Hoofdstuk4gaatinopdeinvloedvanpositiefaffect (eengoedgevoel), kosten-enbatenafwegingen en vertrouwen op de intentie om een persoonlijk voedingsadvies te gaan gebruiken. Met gebruik van representatieve steekproeven in Nederland $(n=2109)$ en Australië $(n=1000)$, en de statistische techniek structural equation modeling is dit proces onderzocht. Hoewel in beide steekproeven het definitieve model goed paste, was er een belangrijk verschil te zien tussen de landen. Voor Australiërs bleek positieve emotie een belangrijke voorspeller van de intentie om een gepersonaliseerd dieet te volgen, terwijl Nederlanders vaker rationele overwegingen maken. Een mogelijke verklaring kan zijn dat in landen waar meer informatie wordt verstrekt individuen hun intentie eerder op rationele overwegingen zullen baseren, terwijl diegenen die over minder informatie beschikken zich op affectieve evaluaties baseren.

Hoofdstuk 5 behandelt de invloed van positief en negatief affect, kosten- en batenafweging, attitude en betrokkenheid op de intentie om een persoonlijk voedingsadvies te volgen. Het theoretisch model, dat is ontwikkeld en getest met data uit een representatieve steekproef in Nederland ( $\mathrm{n}=2170)$, toonde een goede fit. De resultaten tonen aan dat hoe hoger de persoonlijke betrokkenheid bij gepersonaliseerde voeding, des te positiever men is over deze toepassing en hoe groter de intentie is om het voedingsadvies te gaan gebruiken. Het model werd zes maanden later opnieuw getest en gevalideerd ( $n=1636$ van de originele steekproef) en bleek door de tijd heen stabiel. Daarnaast werd de bruikbaarheid van het model voor een ander terrein binnen de voedseltechnologie (functional foods) getest en gevalideerd ( $\mathrm{n}=2084$, nieuwe steekproef).

Hetonderzoeksgebiedvan publiekeperceptievangenomics is tot nu toe nogjongen onontgonnen. Dit proefschrift is een van de eerste stappen naar een beter begrip van het sociaal psychologische proces dat vooraf gaat aan de acceptatie van toepassingen van de nieuwe technologie voedingsgenomics. De resultaten bevestigen het idee uit de affect heuristic: een individu is geneigd om zijn intentie om bijvoorbeeld gepersonaliseerde voeding te gaan gebruiken eerder te baseren op zijn affectieve/emotionele reactie dan op een meer cognitief proces waarbij de kosten en baten van de nieuwe technologie worden afgewogen. De betrokkenheid bij de technologie en de persoonlijke relevantie van de technologie voor het individu vormen een belangrijke voorspeller van zowel het affectieve als het cognitieve proces. Het vertrouwen in betrokken instanties, een determinant die vaak is bestudeerd in het afgelopen decennium, houdt vooral verband met de kosten-en batenafweging en heeft daarom een mindergrote invloed op de intentie om een nieuwe technologie te gaan gebruiken dan werd verwacht. De resultaten uit dit proefschrift dragen bij aan de opvatting dat de persoonlijke relevantie van de toepassingen van de nieuwe technologie 
benadrukt moeten worden bij het introduceren van een nieuwe technologie, zodat voldoende maatschappelijk draagvlak wordt gekregen. Een proactieve beleidsaanpak kan de ontwikkeling stimuleren van toepassingen die voor individuen persoonlijk relevant zijn en daarom positief worden gewaardeerd. 


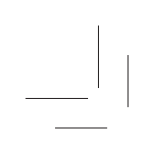

1 


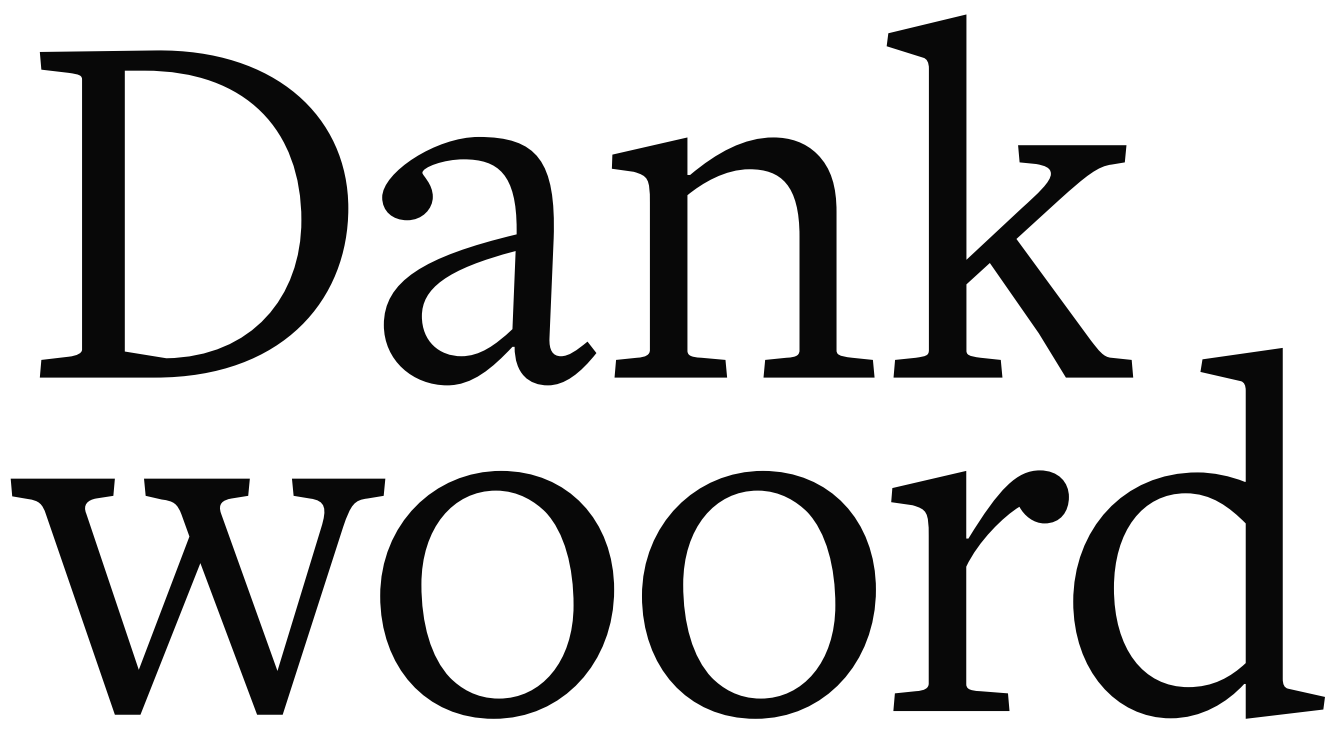




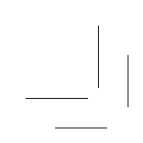

1 


\section{Dankwoord}

In totaal hebben 8.627 mensen meegewerkt aan dit onderzoek. Familie, vrienden en vrienden van vrienden vulden geduldig mijn vragenlijsten in tijdens de pretests. Maar nog veel meer anonieme respondenten namen deel aan het onderzoek, in Australië of gewoon in Nederland. Zoals een anonieme dame, 107 jaar oud. "Impressive" was het commentaar van een reviewer daarop. En dat is het ook. Haar bereidheid om via dit onderzoek bij te dragen aan de ontwikkeling van deze nieuwe technologie, die mogelijk in de toekomst een belangrijke rol gaat spelen in ons dagelijks leven, is van grote waarde. Aan haar en al die anderen: heel hartelijk dank, zonder u geen proefschrift.

Op deze plaats wil ik meer mensen bedanken, zonder wie dit project niet was geworden wat het nu is. Mijn dagelijks begeleider Jan Gutteling. Dank je wel voor alles wat ik van je heb mogen leren in de afgelopen vier jaar. Ik had me geen meer betrokken begeleider kunnen wensen die me te allen tijde met raad en daad bijstond om het onderzoek op een hoger plan te brengen. Mijn promotoren Erwin Seydel en Lynn Frewer. Het was een eer om onder jullie te mogen promoveren. Erwin, bedankt voor je enthousiasme, vertrouwen en de motiverende overleggen. Lynn, thank you for sharing your expertise and for your valuable feedback on my manuscripts. It was an honor working with you.

Daarnaast wil ik prof. dr. Maarten IJzerman, prof. dr. Michaël Steehouder, prof. dr. Patricia Osseweijer, prof. dr. Jan Terlouw, prof. dr. Hub Zwart, en dr. Christine Critchley bedanken voor het plaats nemen in mijn promotiecommissie. De onderzoekers en staf van het Centre for Society and Genomics wil ik bedanken voor de overleggen en onderzoekersdagen en het bieden van de essentiële inbedding van het onderzoek in het veld van de maatschappelijke component van genomics. CentERdata wil ik bedanken voor het mogelijk maken van de dataverzameling en in het bijzonder Annette Scherpenzeel en Corrie Vis voor hun hulp en waardevolle aanbevelingen. Marjolein Drent wil ik bedanken voor haar deskundig advies bij de systematic review.

Christine and Elizabeth, I owe you many thanks for the very warm welcome in Australia and for all your advice, inspiration and support since then. It was absolutely great working with you and I hope we will continue to do so in the future.

Collega's, en speciaal Anne, Ellen, Ellen G., Fenne, Karin, Karlijn, Loes, Marieke, Margôt, Mark, Marlies, Nelly, Nicol, Nicole, Oscar, Somaya en Teun: er komt geen letter op papier in een inspiratieloze werkomgeving en zonder bevlogen rolmodellen. Bedankt voor de discussies, feedback op mijn stukken en wijze raad op de gang, bij de koffieautomaat en bij de printer. 
Fenne en Rido wil ik bedanken voor hun steun tijdens de verdediging van mijn proefschrift als mijn paranimfen. Rido, de grote afstand weerhield je er niet van om op cruciale momenten de kritische vragen te stellen en me uit te dagen met een andere blik te kijken. Dank je wel. Fenne, de afgelopen vier jaar zijn onlosmakelijk verbonden met onze vriendschap. Dank je wel voor je onuitputtelijke optimisme en enthousiasme. LL321.

Dan wil ik iedereen bedanken die er de afgelopen vier jaar was. Met liters (groene) thee, blije vissen, breekijzers en trappen, logeerbedden, telefoontjes (om 8 am), gas-bbq's, dansjes op de Miss Universe, in de regen, in ijssalons en op bankjes in het park, op de Euromast, de Afsluitdijk, Cradle Mountain, C239b, H429, met Amaretto, een rol chocolade koekjes, nieuwe routes door het Twentse land, dagafsluiters, maand cd's, op de porch, in het zwembad, de VB, de Weduwe, met oranje pakken en pruiken, bowlingballen, home made speculaas scones, met DJ Marco V, met Que Bonita Es Esta Vida, op een tandem, op stelten, op een step, op dushi Korsow, in Parijs, Antwerpen, Den Haag, Ljubljana, London, Melbourne, Sydney, Hobart, Breda, Boston, New York, Gent, Utrecht, big city Enschede en/of elke andere plaats.

Mam en pap, jullie staan altijd achter me. Dank jullie wel voor jullie onvoorwaardelijke steun, wijsheid en vertrouwen. De rijst is op, het boek is af. Oma, zonder jouw goede zorgen en betrokkenheid, met name vanaf het moment dat ik in 1997 weer voet zette op Hollandse bodem, had ik hier niet gestaan. Dank je wel voor alles.

Lieve mam, pap, Rido en oma, de wereld is groot en het leven vol onverwachte wendingen. Dat jullie straks op de eerste rij zitten lijkt vanzelfsprekend, maar is voor mij een heel bijzondere afsluiting van de afgelopen vier jaar. Ik ben heel blij dat jullie er zijn.

Renske Pin

April 2009 


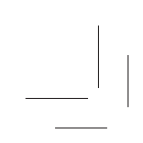

1 


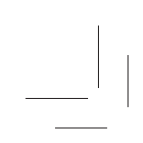

1 


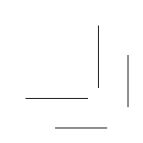

1 


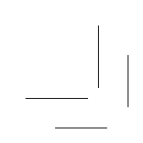

1 